\title{
The food system transformation in developing countries: opportunities and challenges for smallholder farmers in Thailand
}

\author{
Dissertation \\ zur Erlangung des Doktorgrades \\ im Promotionsstudiengang Agrarwissenschaften (PAG) \\ der Fakultät für Agrarwissenschaften, \\ der Georg-August-Universität Göttingen
}

vorgelegt von

Christin Schipmann

geboren in Meppen

Göttingen, April 2010 
D7

1. Name of supervisor: Prof. Dr. Matin Qaim

2. Name of co-supervisor: Prof. Dr. Meike Wollni

Date of dissertation: 20.05.2010 
In loving memory of my mum 
'We have the means and the capacity to deal with our problems, if only we can find the political will.'

Kofi Annan 


\section{Summary}

In many developing countries, agricultural and food systems are undergoing a major transformation towards high-value, modern supply chains. In export markets, standards and certification systems are gaining in importance, while within developing countries, the role of national and multinational super- and hypermarket chains is growing. These developments have important implications for various stakeholders in the agro-food system, including, in particular, smallholder farmers.

One country where the expansion of modern retail structures started relatively early is Thailand. In the 1980s and 90s increasing per capita incomes, urbanization trends and female labor force participation spurred, among other things, the development of modern retail structures. In 1996, the five most important ${ }^{1}$ super- and hypermarket chains had a total of 36 branches, and by 2009 , this number of branches had already increased to 295 . While modern retail markets first focus on attracting consumers with an all-in-one shopping strategy and particularly low prices for processed foods and staples, their stores start to mimic wet market situations in an advanced devel-

\footnotetext{
${ }^{1}$ In this context, 'importance' is measured by number of branches of existing super- and hypermarket chains.
} 
opment stage. Although some barriers exist, e.g. a continuous cool chain, the share of fresh produce sales (as a percentage of total food sales) is also increasing at modern retail markets. Taking into account the importance of fruit and vegetable production for smallholder farmers, our study focuses on the fresh fruit and vegetable sector. In the first chapter, we analyze how smallholder farmers in developing countries can benefit from modern supply chains. We take the example of sweet pepper, which was introduced as a product innovation in Thailand some 10 years ago, mainly for exports and upscale domestic supermarkets. Over time, sweet pepper gained wide popularity among domestic consumers, so that nowadays it is also traded at more traditional wholesale and retail markets.

Our analysis is based on original farm survey data from 246 sweet pepper producers and 62 non-sweet pepper farmers in the Mae Sa Watershed in northern Thailand. Results from our regression models show that sweet pepper cultivation, and in particular an early adoption, contributes significantly to higher household incomes and is therefore an important potential avenue for smallholder farmers to improve their livelihood. However, the duration analysis indicates that missing land titles, weak infrastructure conditions and limited access to information constituted serious constraints during the early phases of sweet pepper adoption. There must be a change in policy in order to overcome these initial adoption constraints for disadvantaged farmers, and to thus avoid negative income distribution effects. Strikingly, at this stage, participation in modern supply chains does not lead to higher incomes than when supplying sweet pepper to traditional markets. This finding underlies that spillovers from modern retail markets should not be underestimated; they must be accounted for in future studies of the wider implications of modern supply chains.

Modern retail markets not only bring new products and product standards - they also implement profound changes in supply chain management, thereby affecting farmers' marketing decisions. Super- and hypermarkets increasingly modernize their procurement systems and switch from buying through spot-market transactions to contractual agreements with farmers, often through specialized intermediaries. In the second chapter, we used the data from the above-mentioned farm survey to compare institutional arrangements, including contracts, between farmers and traders in traditional and modern supply chains of sweet pepper. Moreover, we assess the impact of 
those differences on the farmers' market channel choice. Our descriptive comparison of institutional arrangements confirms that significant differences exist among marketing channels.

Furthermore, we show that some of those differences influence the farmers' marketing behavior. While output prices matter, the farmers also value other aspects such as access to inputs, credit and information, as well as independence and flexibility. Results from the choice experiment additionally point out the farmers' general preference for marketing options that do not involve a contract, and confirm that the aspects mentioned above can increase the attractiveness of contracts. Yet, the most important factor for the farmers is a personal relationship with the buyer, which seems to reflect their desire for mutual trust. These findings show that beyond addressing market imperfections, designing institutional arrangements according to the farmers' needs can also contribute to more widespread smallholder participation in modern retail markets.

The integration of smallholder farmers in modern retail markets is one way to improve their livelihood. However, our previous analyses show that various barriers exist that continue to limit integration possibilities. We showed that traditional markets can also offer financial incentives to smallholder farmers and, in many ways, traditional marketing structures correspond to the marketing preferences of smallholder farmers. It is therefore also important to know how much traditional retail structures, and in particular, wet markets, are affected by food system transformations. We consider this issue in the third chapter when we analyze the competition strategy of modern retail outlets with regard to product prices and observable product quality attributes. We again focus on the fresh fruits and vegetables segment, and in particular, on two products: morning glory and sweet pepper. We collected data about these products' quality attributes and prices on 43 market outlets in 17 districts of Bangkok. The sample comprises 14 branches of the three most important supermarket chains and 12 branches of the three most important hypermarket chains, as well as 17 wet markets. Descriptive comparisons of product prices and quality among the three types of markets show that neither super- nor hypermarkets are price competitive with wet markets. However, super- and hypermarkets offer higher prod- 
uct quality. Results from hedonic price models show that certain quality attributes significantly increase product prices.

Moreover, we find a price effect of modern retail outlets, which demonstrates that despite any potential differences in quality, prices in super- and hypermarkets are higher than in wet markets. This shows that consumers not only value specific quality attributes, but also modern retail formats. The overall picture resulting from this analysis is that traditional and modern markets have been acting more as complements to one another than as competitors. However, since modern retail formats primarily serve the middle and upper income classes, these markets are reaping the most benefits from overall economic growth. Wet markets - and the majority of smallholder farmers - are being left behind.

All in all, the results of this study have important policy implications for the support of smallholder farmers in emerging economies. On the one hand, the integration of smallholder farmers should continue to be promoted. This would require government involvement with regard to overcoming widespread market imperfections, like weak infrastructure conditions and limited access to market information. Furthermore, the relationship between the farmers and buyers needs to be improved. This is especially important regarding company representatives and intermediaries, who are often nonlocals. One possible approach could be to more explicitly involve local traders who have established long-term relationships with the farmers. In areas where this is not logistically possible, companies and intermediaries could try to improve their ties with the farmers through other trust-building mechanisms, such as increasing the number of personal interactions and making pricing and grading procedures more transparent. On the other hand, the importance of wet markets as a major market outlet for smallholder farmers should not be forgotten. In order to attract middle and high income classes, and thereby benefit from overall economic growth, wet markets need to adapt to changing consumer demands. This can only be achieved by increasing the overall attractiveness of wet markets, e.g. by improving the hygienic conditions and offering more parking lots, as well as by expanding the product assortment. However, traders have a limited capacity to influence market modernization; such measures need to be supported with financial means and know-how by the government and/or private investors. 


\section{Zusammenfassung}

Landwirtschaftliche Märkte sowie die gesamte Ernährungswirtschaft unterliegen in vielen Entwicklungsländern enormen Transformationsprozessen hin zu modernen Wertschöpfungsketten und der Erzeugung hochqualitativer Produkte. Während in den Exportmärkten Produktstandards und Zertifizierung an Bedeutung gewinnen, spielen in Entwicklungsländern nationale und multinationale Super- und Hypermarktketten eine immer größere Rolle. Diese Entwicklungen haben Auswirkungen auf die verschiedenen Akteure der Ernährungswirtschaft, insbesondere auf Kleinbauern.

Ein Land, in dem die Expansion von modernen Einzelhandelsstrukturen schon relativ früh begonnen hat, ist Thailand. In den 1980er und 1990er Jahren haben, neben anderen Faktoren, das steigende Pro-Kopf Einkommen, erhöhte Urbanisierungsraten sowie die zunehmende Arbeitstätigkeit von Frauen die Etablierung von modernen Einzelhandelsstrukturen beschleunigt. Während die fünf wichtigsten ${ }^{2}$ Super- und Hypermarktketten 1996 insgesamt 36 Filialen in Thailand hatten waren es 2009 bereits 295 Filialen. $\mathrm{Zu}$ Beginn der Entwicklung waren moderne

\footnotetext{
${ }^{2}$ Wichtig ist hier gemessen an der Anzahl an Filialen einer Super-/Hypermarktkette.
} 
Einzelhandelsgeschäfte darauf fokussiert, Konsumenten mit umfassenden Einkaufsmöglichkeiten sowie mit niedrigen Preisen für Grundnahrungsmittel und verarbeitete Produkte zu werben. Je mehr sich die Märkte allerdings etablieren, desto wichtiger werden auch frische Lebensmittel, wie z.B. Obst und Gemüse. Auch wenn die Ausweitung dieses Produktsegments durch bspw. die Notwendigkeit einer durchgängigen Kühlkette erschwert wird, steigt der Verkaufsanteil von frischen Lebensmitteln an den totalen Lebensmittelverkäufen von modernen Einzelhandelsmärkten an. Da diese Produktkategorie eine wesentliche Bedeutung für Kleinbauern hat, liegt der Fokus dieser Studie auf frischen Lebensmitteln, insbesondere auf Gemüse.

Das erste Kapitel untersucht am Beispiel von Paprika, wie Kleinbauern in Entwicklungsländern besser von modernen Wertschöpfungsketten profitieren können. Paprika ist ein Gemüse das erst vor etwa 10 Jahren als Produktinnovation in Thailand eingeführt wurde, um auf Exportmärkten und im modernen Lebensmitteleinzelhandel verkauft zu werden. Im Laufe der Zeit hat Paprika bei den lokalen Konsumenten an Popularität gewonnen und er wird heute auch auf traditionelleren Lebensmittelmärkten gehandelt. Die Analyse basiert auf Daten einer Haushaltserhebung im Wassereinzugsgebiet Mae Sa in Nordthailand. Die Erhebung umfasst 246 Paprika produzierende Haushalte sowie 62 landwirtschaftliche Haushalte, die keinen Paprika produzieren. Ergebnisse der Regressionsmodelle zeigen, dass die Kultivierung von Paprika, und insbesondere ein früher Einstieg in die Paprikaproduktion, signifikant zu höherem Haushaltseinkommen beiträgt und damit eine wichtige Strategie für Kleinbauern darstellt, ihre Lebenssituation zu verbessern. Es gilt allerdings zu bedenken, dass fehlende Landrechte, eine schwache infrastrukturelle Anbindung sowie fehlender Zugang zu Informationen Barrieren für eine frühe Übernahme der Kultivierung von Paprika darstellen. Es ist daher eine ernsthafte Herausforderung für die Politik, diese Hindernisse zu überwinden um negative Einkommenseffekte für benachteiligte Landwirte $\mathrm{zu}$ verhindern. Die Integration in moderne statt in traditionelle Wertschöpfungsketten trägt bisher allerdings nicht zu einem erhöhten Einkommen bei. Dieses hebt noch einmal hervor, dass externe Effekte, die durch die Etablierung modernen Einzelhandelsmärkten 
entstehen, bei der Bewertung dieser Märkte nicht unterschätzt werden sollten und in zukünftigen Studien berücksichtigt werden müssen.

Der moderne Lebensmitteleinzelhandel führt nicht nur zu neuen Produkten und Produktstandards, sondern auch zu substantiellen Veränderungen im Management von Wertschöpfungsketten, was die Vermarktungsentscheidungen von Landwirten ebenfalls beeinflussen kann. Super- und Hypermärkte modernisieren zunehmend ihr Beschaffungswesen, was unter anderem bedeutet, dass sie vermehrt auf vertragliche Absprachen mit ihren Lieferanten bestehen. Landwirte beliefern Supermärkte häufig nicht mehr direkt, sondern sind über Zwischenhändler mit diesen Märkten verbunden. Basierend auf den Daten der oben genannten Haushaltserhebung werden im zweiten Kapitel die (vertraglichen) Vereinbarungen zwischen Landwirten und Händlern in traditionellen und modernen Wertschöpfungsketten für Paprika verglichen. Darüber hinaus ist es von Interesse zu analysieren, inwiefern bestehende Unterschiede die Entscheidung eines Landwirtes für einen bestimmten Vermarktungsweg beeinflussen. Die Ergebnisse bestätigen die Annahme, dass zwischen den Vermarktungswegen signifikante Unterschiede in Vereinbarungen zwischen Landwirten und Händlern bestehen. Außerdem zeigen die Ergebnisse, dass einige dieser Unterschiede die Vermarktungsentscheidungen von Landwirten beeinflussen. Produktpreise spielen für Landwirte ebenso wie das Bereitstellen von Betriebsmitteln und Krediten und die eigene Unabhängigkeit und Flexibilität eine wichtige Rolle. Die Ergebnisse des Choice Experimentes stellen heraus, dass Landwirte im Allgemeinen eine Präferenz für Vermarktungswege haben, die keine vertraglichen Vereinbarungen beinhalten. Außerdem bestätigt das Experiment, dass einige der oben genannten Aspekte (z.B. die Bereitstellung von Krediten) die Attraktivität von Verträgen erhöhen. Der wichtigste Aspekt für Landwirte ist allerdings eine gute persönliche Beziehung zum Händler, was darauf schließen lässt, dass Landwirte ein gewisses Maß an Vertrauen wertschätzen. Zusammenfassend zeigen diese Ergebnisse, dass für die bessere Einbindung von Kleinbauern in moderne Einzelhandelsstrukturen nicht nur die Mängel landwirtschaftlicher Märkte überwunden werden müssen, sondern auch berücksichtigt werden sollte, wie Absprachen zwischen Landwirten und Händlern gestaltet werden. 
Die Einbindung von Kleinbauern in den modernen Einzelhandel hat das Potential, die Lebensumstände von Kleinbauern zu verbessern. Die vorherigen Ergebnisse verdeutlichen allerdings, dass verschiedenste Barrieren bestehen, die eine weitreichende Integration von Kleinbauern nach wie vor erschweren. Darüber hinaus zeigen die Ergebnisse, dass auch traditionelle Märkte finanzielle Anreize für Landwirte bieten können und dass traditionelle Vermarktungsstrukturen den Präferenzen von Landwirten teilweise besser entsprechen. Daher ist es ebenfalls wichtig abzuschätzen, inwiefern traditionelle Einzelhandelsstrukturen, insbesondere die Märkte für Frischwaren, von der Transformation der Ernährungswirtschaft betroffen sind. Dieser Aspekt wird im dritten Kapitel aufgegriffen, in dem die Wettbewerbsstrategie von Super- und Hypermärkten in bezug auf Preise und erkennbare Qualitätsattribute zweier Gemüsesorten, Morning Glory und Paprika, verglichen wurde. Dafür wurden Daten über bestimmte Qualitätsattribute und Preise auf 43 Märkten in 17 Distrikten von Bangkok erhoben. Die Stichprobe besteht aus insgesamt 14 Filialen der drei wichtigsten Supermarktketten und insgesamt 12 Filialen der drei wichtigsten Hypermarktketten sowie 17 traditionellen Märkten für Frischwaren. Der Vergleich der Preise und der Qualitätsattribute auf den verschiedenen Märkten zeigt, dass weder Super- noch Hypermärkte in Bezug auf die Preise wettbewerbsfähig mit traditionellen Märkten für Frischwaren sind. Im Gegensatz dazu bieten diese Märkte Produkte höherer Qualität an. Die Ergebnisse des hedonischen Preismodells legen dar, dass auf allen Märkten bestimmte Qualitätsattribute die Produktpreise signifikant beeinflussen. Darüber hinaus haben Super- und Hypermärkten einen signifikanten und positiven Einfluss auf die Produktpreise. Dieses Ergebnis lässt darauf schließen, dass moderne Lebensmittelmärkte als solches für Konsumenten einen gewissen Wert darstellen, da sie bereit sind unabhängig von Qualitätsunterschieden, höhere Produktpreise zu bezahlen. Allerdings sind die Konsumenten der mittleren und höheren Einkommensklassen eher Kunden moderner Einzelhandelsmärkte, so dass das allgemeine Wirtschaftswachstum vor allem dem modernen Lebensmittelsektor zugute kommt. Traditionelle Märkte für Frischwaren und damit der Großteil an Landwirten bleiben weitgehend außen vor. 
Aus den Ergebnissen dieser Studie lassen sich wichtige Politikempfehlungen für die Unterstützung von Kleinbauern in Entwicklungsländern ableiten. Einerseits sollte die Integration von Kleinbauern in moderne Einzelhandelsstrukturen weiter gefördert werden. Dafür müssen Regierungen sich aktiv engagieren, um das Funktionieren der landwirtschaftlichen Märkte zu verbessern, bspw. durch Investitionen in die Infrastruktur oder die Verbesserung des Zugangs von Kleinbauern zu Marktinformationen. Darüber hinaus müssen die Beziehungen zwischen Kleinbauern und den nicht lokalen Händlern verbessert werden. Ein Ansatz in diese Richtung ist eine bessere Einbindung von lokalen Händlern, die häufig schon lang andauernde Beziehungen mit Landwirten haben. Wo dieses logistisch nicht möglich ist, sollten Unternehmen in Vertrauensbildende Maßnahmen investieren, z.B. in häufigere persönliche Kontakte $\mathrm{zu}$ den Landwirten oder in transparente Preisbildung. Andererseits sollte die Bedeutung von traditionellen Märkten für Frischwaren nicht aus den Augen verloren werden. Um Kunden der mittleren und höheren Einkommensklassen $\mathrm{zu}$ gewinnen und dadurch auch vom allgemeinen Wirtschaftswachstum zu profitieren müssen sich diese Märkte an die sich verändernden Einkaufsgewohnheiten von Konsumenten anpassen. Dazu muss die allgemeine Attraktivität der Märkte, z.B. durch die Verbesserung der hygienischen Standards oder durch die Ausweitung des Angebots an Parkplätzen, verbessert werden. Darüber hinaus muss auch das Produktangebot angepasst werden. Diese Veränderungen können jedoch nur zum Teil von den Händlern selbst getragen werden. Vor allem bedarf es der Unterstützung der Regierung und/oder privater Investoren, die finanzielle Mittel und Know-how zur Verfügung stellen. 


\section{Acknowledgments}

I am deeply indebted to many people who have helped and accompanied me during the process of working on this dissertation. Most importantly, I am grateful to my supervisor, Prof. Dr. Qaim. He constantly provided scientific advice and support, and nevertheless gave me the freedom and flexibility to follow my own ideas. His commitment to my work enabled me to learn a great deal; I appreciate it very much.

My appreciation and thanks also go to my second supervisor, Prof. Dr. Wollni. Her moral support always encouraged me, as did our fruitful discussions. I also would like to thank Prof. Dr. Spiller, who immediately agreed to be my third supervisor. I also gratefully acknowledge the financial support of the DFG, who funded my research project as a part of the Uplands Program. Furthermore, I would like to thank Lou Priven for his proofreading skills and flexibility.

My work is based on field surveys in Thailand, and I would like to mention a word of gratitude for my assistants in Chiang Mai and Bangkok. Thanks for the implementation of the household and market surveys, for giving me insights into Thai culture and for your openness towards my own cultural background. Furthermore, I am indebted to all our respondents for patiently answering all our questions. A special 
thank-you goes to my counterpart Rattiya Suddeephong, not only for her tremendous support during my stays in Thailand, but also for her willingness to help with any consultations I had after I had returned to Germany.

There are also a number of people in Germany who have helped me. First of all, I would like to thank my colleagues from the Department of Agricultural Economics and Social Science in the Tropics and Subtropics at Hohenheim University, where I started my $\mathrm{PhD}$. In particular, I would like to express my gratitude to Marcus Mergenthaler, who was always open to all of my questions and concerns, even after he had left the university. Sincere thanks go to Bianca Haußner and Camille SaintMacary, who helped me handle the cultural shock of moving from Berlin to Swabia. I would also like to offer special thanks to Magarete Karras and the Uplands office in Hohenheim for their valuable support in helping me deal with administrative hassles. I am also very grateful for having such wonderful colleagues and a fantastic working atmosphere at the Chair of International Food Economics and Rural Development of the Georg-August-University in Göttingen. Special thanks go to my office-mate and friend James Rao. Whenever needed, he supported me with (econometric) advice, and his trust in my work always encouraged me. I have enjoyed his companionship very much. I also thank Christina Seebens-Elverfeldt for being the best role model in 'How to finish a $\mathrm{PhD}$ thesis while remaining perfectly calm'. I thought about her attitude many times during the final weeks of working on my dissertation.

There are still more people who accompanied me during the process of writing my dissertation. In particular, I want to express my gratitude for mental support to Xenia van Edig, Jana Juhrbandt, Christoph Sänger and Cornelia Römling. Moreover, I thank Katrin Niemann, Andrea Schmidt, Beate Thießen, Daniela Wannemacher and Thordis Möller for their great friendship. I am also grateful to Annemarie Schlösser for her constant support throughout the last few years.

My unending gratitude is dedicated to Stefan Schwarze. I cannot imagine that a person can be more loving and supporting. 


\section{Table of Contents}

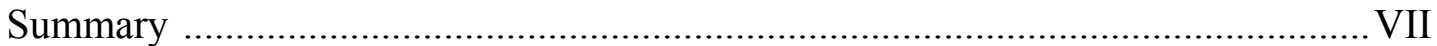

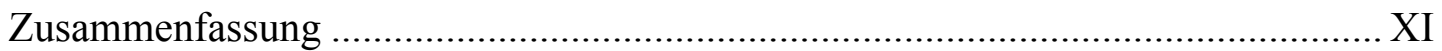

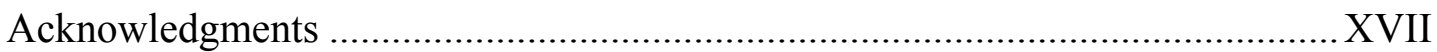

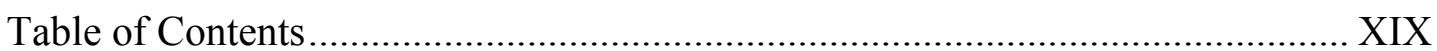

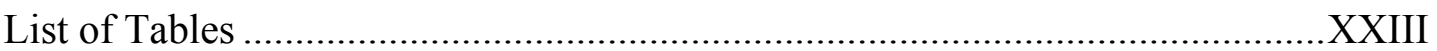

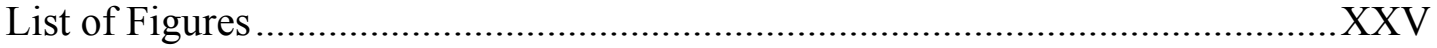

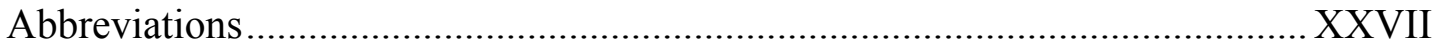

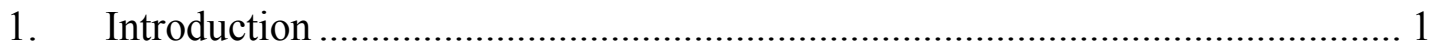

2. Spillovers from modern supply chains to traditional markets: product innovation and adoption by smallholders....................................................... 11

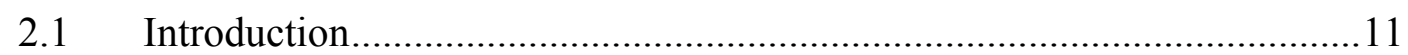

2.2 Background on sweet pepper cultivation in Thailand and database ............13

2.2.1 Sweet pepper cultivation and marketing channels................................. 13

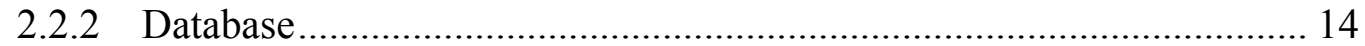

2.3 Explaining farmers adoption decisions.....................................................

2.3.1 Comparison of adopters and non-adopters ......................................... 16 
2.3.2 Specification of probit adoption models.............................................. 18

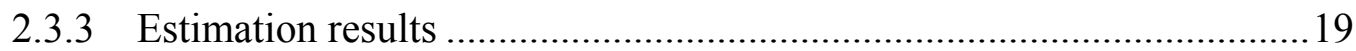

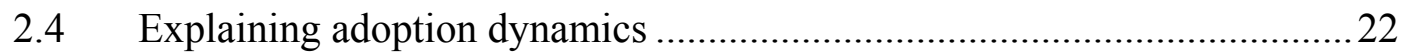

2.4.1 Background on duration models.......................................................22

2.4.2 Specification of the duration model.................................................23

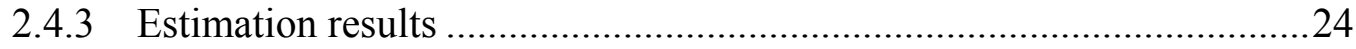

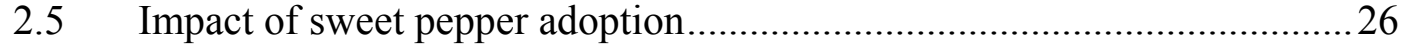

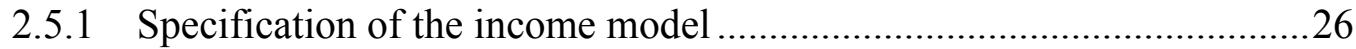

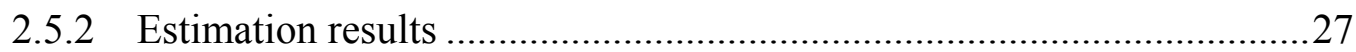

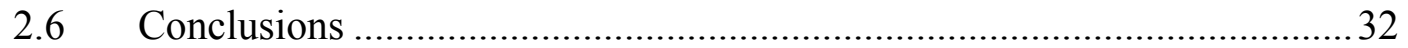

3. Supply chain differentiation, contract agriculture, and farmers' marketing preferences: the case of sweet pepper in Thailand ...........................................35

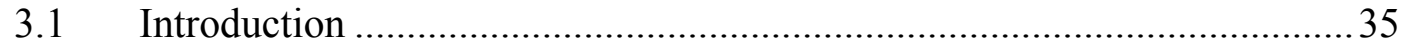

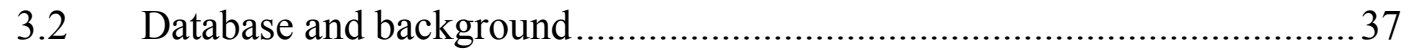

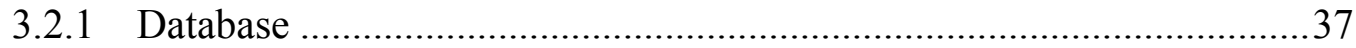

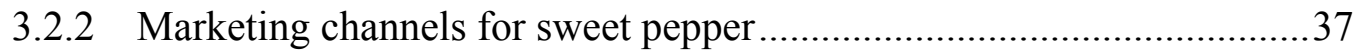

3.3 Supply chain differentiation and contractual arrangements ........................39

3.3.1 Contractual arrangements in different marketing channels....................39

3.3.2 Comparison of contract details ............................................................40

3.4 Reasons for farmers' marketing decisions .............................................. 43

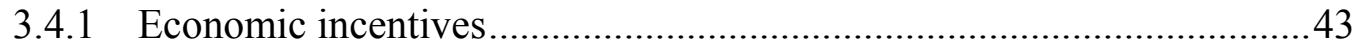

3.4.2 Subjective reasons stated by farmers.................................................. 45

3.5 Farmers' marketing preferences: a choice experiment.............................. 48

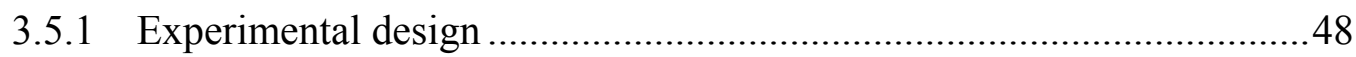

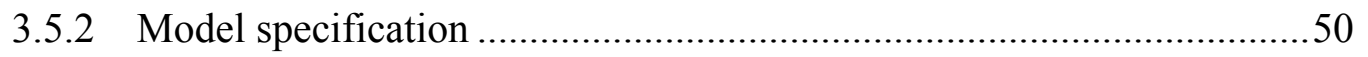

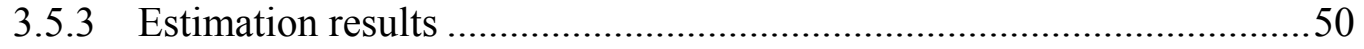

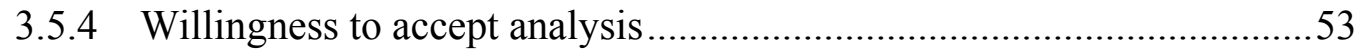

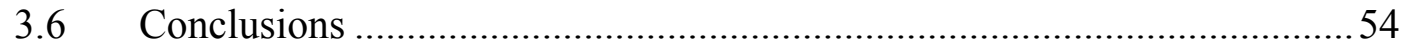

4. Implications of the expansion of modern retail structures for traditional markets: the case of wet markets in Thailand .................................................5

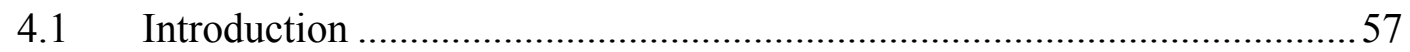

4.2 Background on modern retail markets in Thailand and database...............60 
4.2.1 The development of modern retail structures in Thailand .................... 60

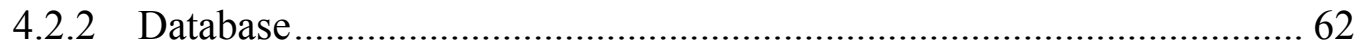

4.3 Comparison of price and quality differences between market outlets........64

4.3.1 Description and comparison of different market outlets ...................... 64

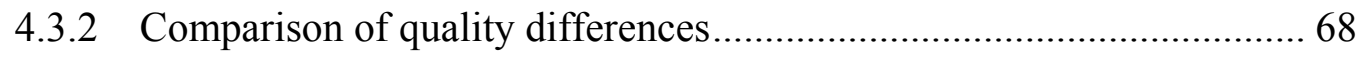

4.3.3 Comparison of price differences …............................................... 72

4.4 Price premia for market outlet and product quality .................................. 74

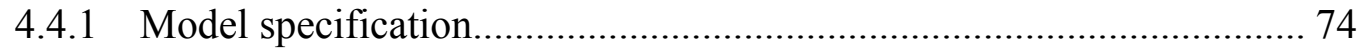

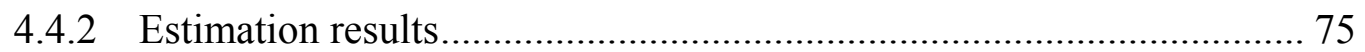

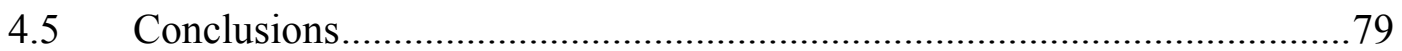

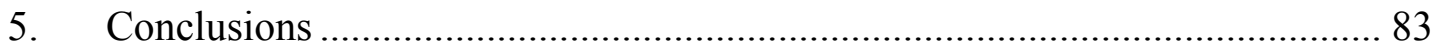

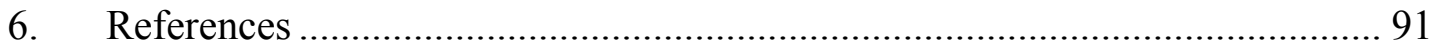




\section{List of Tables}

Table 1: Descriptive statistics for different groups of adopters and non-adopters .... 17

Table 2: Determinants of sweet pepper adoption ...................................................... 20

Table 3: Parametric estimation of the hazard rate of adoption .................................. 25

Table 4: Impact of sweet pepper adoption on household income............................ 29

Table 5: Impact of timing of sweet pepper adoption on household income (OLS)... 31

Table 6: Input delivery and payment mode for output sales (in \%) ......................... 41

Table 7: Timing and duration of contracts (in \%) ...................................................... 42

Table 8: Average sweet pepper prices in Thai Baht per kg ..................................... 43

Table 9: Gross margin analysis in Thai Baht per acre ............................................. 44

Table 10: Farmers' perceived advantages of supplying to a particular marketing channel (in \%)................................................................... 46

Table 11: Farmers' stated reasons for changing marketing channels (in \%)............. 47

Table 12: Marketing channel attributes and attribute levels used in the

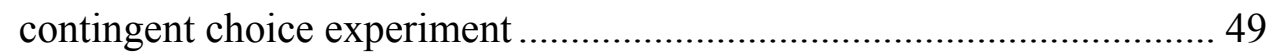

Table 13: Random parameter logit model for farmers' market channel choice ........ 52

Table 14: Quality attributes for morning glory and sweet pepper........................... 64 
Table 15: Comparison of various market features in $2009(\%)$................................65

Table 16: Quality differences for morning glory by retail outlet ............................69

Table 17: Quality differences for sweet pepper by retail outlet ..............................71

Table 18: Product prices per market outlet in Baht $/ \mathrm{kg}$......................................... 73

Table 19: Hedonic price regression (pooled regression) …...................................... 75

Table 20: Hedonic price regression for morning glory ......................................... 77

Table 21: Hedonic price regression for sweet pepper ............................................ 78 


\section{List of Figures}

Figure 1: Sweet pepper adoption and the role of different marketing channels 15

Figure 2: Sweet pepper adoption and supply of different marketing channels, $1999-2007$ 38

Figure 3: Importance of contracts by marketing channel, 2007 39

Figure 4: Aspects that are regulated in contracts by marketing channel 40

Figure 5: Leading super- and hypermarket chains in Thailand, 1996-2009. 61

Figure 6: Spatial distribution of retail chain branches in Thailand, 2009. 62 


\section{Abbreviations}

$\begin{array}{ll}\text { AIC } & \text { Akaike Information Criterion } \\ \text { ASC } & \text { Alternative Specific Constant } \\ \text { Bzw. } & \text { Beziehungsweise } \\ \text { E.g. } & \text { Example Given } \\ \text { FDI } & \text { Foreign Direct Investment } \\ \text { FIML } & \text { Full Information Maximum Likelihood } \\ \text { FFV } & \text { Fresh Fruits and Vegetables } \\ \text { GAP } & \text { Good Agricultural Practice } \\ \text { GDP } & \text { Gross Domestic Product } \\ \text { i.e. } & \text { Id Est } \\ \text { Kg } & \text { Kilogram } \\ \text { OLS } & \text { Ordinary Least Square } \\ \text { RPL } & \text { Random Parameters Logit } \\ \text { WTP } & \text { Willingness to Pay } \\ \text { WTA } & \text { Willing to Accept } \\ \text { z.B. } & \text { Zum Beispiel }\end{array}$




\section{Introduction}

In 2002, around $75 \%$ of the world's poor were living in rural areas; most are directly or indirectly dependent on agriculture (World Bank, 2008). This is why the majority of agricultural research performed in developing countries focuses on the question how to improve agricultural systems to support the livelihood of the poor. The fact that poverty figures are still high, despite all the efforts of research, development aid and cooperation, illustrates the complexity of this task. The motivation of this study was to contribute to the understanding of how agricultural systems are changing, and to identify which kinds of support smallholder farmers need in order to adapt to these changes and improve their livelihood.

\section{Agriculture as an avenue out of poverty}

The importance of agriculture for poverty reduction has long been recognized. It was lately stressed again by the World Bank, which, for the first time in 25 years, dedicated its 2008 annual World Development Report to agriculture. Agricultural growth is known to be an important instrument for poverty reduction. Cross-country estimates show that growth in agriculture-based gross domestic product (GDP) is at least 
twice as effective in reducing poverty as non-agriculture GDP growth (World Bank, 2008). This holds true especially for countries which are still agricultural-based, i.e. many developing countries. Moreover, agriculture growth has positive spillover effects to other sectors and rural development, as the agricultural sector is strongly linked to sectors outside of agriculture (Maertens, 2009; World Bank, 2008).

\section{The new role of agricultural markets in developing countries}

There are several ways to support smallholder farmers in developing countries. For a long time the focus was on improving agricultural production systems; nowadays, however, it is recognized that efficient production of agricultural goods is not an end in and of itself. Moreover, lucrative markets for produced goods are needed, and farmers must be given access to these markets.

Profitable markets for agricultural goods were first found in industrialized countries. For a long time agricultural exports from developing countries comprised only commodities like coffee or tobacco, yet growing welfare, changing consumer preferences and trade liberalization have spurred, among other things, the demand for exotic products in industrialized countries (Carletto et al., 1999; Singh, 2002; Reardon and Timmer, 2007). Exports of non-traditional products, such as fruits and vegetables, which are the focus of this study, were thus seen as a new strategy to increase the income of smallholder farmers (von Braun, 1989).

This concept, however, has limitations. Many developing countries followed the strategy of export diversification; this resulted in fierce competition. Because significant increases in the total trade volume could not be expected, only the most efficient producers remained in the market, and these 'winners' were unlikely to be among the poorest producers (Singh, 2002; Carletto et al., 2007). Moreover, exports face a set of ever-increasing entry barriers. Issues of particular concern are product quality and safety standards set up by the government and/or private businesses in industrialized countries (Carletto et al., 1999; Swinnen, 2007). Empirical evidence from agricultural economics literature confirms that export markets offer financial benefits (Maertens and Swinnen, 2009; Minten et al. 2009); however, they also impose requirements and regulations which are often difficult for smallholder farmers to fulfill (Dolan and Humphrey, 2000; Gibbon, 2003; Humphrey et al., 2004). Furthermore, exports of horticultural products account for only a minority of horticultural produc- 
tion in developing countries (Hu et al., 2004; Reardon and Berdegué, 2002). Therefore, domestic markets still remain the most important market for smallholder farmers' horticultural production. National markets for agricultural products are, however, also undergoing a major transformation towards modern retail structures, offering interesting, new possibilities for farmers. Strategies are needed to enable smallholder farmers to be integrated into these markets.

\section{Transformation of agro-food systems in developing countries}

Traditional retail structures in developing countries are characterized by spot-market transactions, which often take place at the farm gate. Agricultural goods are then traded via networks of informal traders from areas of e.g. vegetable production to regional and national wholesale and retail markets (Meijer et al., 2008). These traditional markets tend to be single units, as opposed to chains; such units are characterized by long marketing channels, direct payment to suppliers and little or no quality control or grading (Meijer et al., 2008; Neven and Reardon, 2008). Although such marketing structures still exist, a continuous establishment of modern retail structures, often parallel to the existing traditional structures, can be observed. Such structures typically include state-of-the art technologies (cashier system, refrigeration at different temperatures, etc.), limited intermediate stages and planned, well-regulated market transactions, which are often guaranteed through contractual arrangements with suppliers (Dirven and Faiguenbaum, 2008; Reardon and Timmer, 2007).

In the following pages we summarize the different formats of modern retail markets under the term 'supermarkets'. The expansion of supermarkets in developing countries occurred in several waves (Reardon and Timmer, 2007). The first wave started in the 1990s and included several countries in South America (e.g. Brazil), East Asia (except China) and South Africa. By the early 2000s supermarkets' share of food retail in those countries had already reached 50 - 60\% (Dirven and Faiguenbaum, 2008; Farina, 2002; Reardon et al., 2003). The second wave countries included South Korea and Thailand as frontrunners, as well as other countries in Southeast Asia, Central America (e.g. Guatemala) and southern Central Europe (e.g. Bulgaria). Supermarket expansion started in these countries in the late 1990s; by the early $2000 \mathrm{~s}$, supermarkets' share of total food retail sales was around $50 \%$ for the frontrunners and $30-50 \%$ for the majority of the other countries in the second wave (Reardon and 
Timmer, 2007; TDRI, 2002). Various African countries (e.g. Kenya), as well as the lagging countries in South America (e.g. Peru) and Southeast Asia (e.g. Vietnam) make up the third wave countries, where supermarkets reached a $10-20 \%$ share of national food retail by 2003 (Reardon and Timmer, 2007). China, India and Russia also belong to the group of third wave countries. Due to the size of their food markets, they are now the preferred destinations for the expansion of modern retail structures (Reardon and Timmer, 2007).

Supermarkets were already present in some developing countries before the 1990s. These markets were, however, owned by local firms, whereas the supermarkets found today mainly belong to the same multinational retail chains (e.g. Carrefour, Tesco Lotus) which are also found in industrialized countries. Moreover, before the $1990 \mathrm{~s}$, the average market share of national food retail sales was around $5-10 \%$, thus representing a niche market (Reardon and Timmer, 2007).

\section{Factors driving the transformation of agro-food systems}

The speed and spatial distribution of the expansion of modern retail structures is determined by the interplay of various factors. First of all, economic growth in developing countries resulted in larger real mean per capita incomes (Reardon et al., 2003), enabling many households to be able to fulfill their basic needs and also spend money on luxury foodstuffs like meat or vegetables (World Bank, 2008). According to Engel's law, the share of income spent on foodstuffs decreases with increasing income. However, the diversity of consumption is increasing, including a decreasing share in the consumption of staples, as stated in Bennett's law (Reardon and Timmer, 2007). Increasing consumption diversification is also spurred by urbanization; one consequence of this is the entry of women into the workforce outside of the home. This increased the opportunity costs of women's time to go shopping and prepare food, resulting in preferences for convenience and processed foods. In sum, the observed changes can be summarized under the term 'the westernization of diet' (Pingali, 2006).

Changing preferences increased consumers' demand for technological progress, e.g. for refrigerators and cars (Reardon et al., 2010). Moreover, the supply side needed technological advances, like refrigeration at different temperatures, improvements to shipping and storage facilities, and computer systems in order to respond to the con- 
sumers' new preferences. These technological advancements thus provided modern retail markets with efficient product management and reduced transaction costs (Reardon and Timmer, 2007). Another important aspect which enormously aided the expansion of supermarkets in developing countries started in the mid-1990s, when those countries' markets were opened to foreign direct investment (FDI) (Reardon and Timmer, 2007; Reardon et al., 2009). Investments in developing countries' markets made by international retail chains from the US, Europe and Japan were driven by the saturation and intense competition on their home markets, whereas markets in developing countries were still growing and offered much higher margins with less competition (Gutman, 2002; Reardon and Timmer, 2007). One result of these investments was a rapid consolidation and 'multi-nationalization' of the supermarket sectors in developing countries. For example, in Latin America, the top five supermarket chains per country have $65 \%$ of the supermarket sector, and in Mexico, foreign supermarket chains accounted for $53 \%$ of all retail sales made by the top seven chains (Reardon et al., 2010).

\section{Supermarket expansion in developing countries}

While the speed of supermarket expansion differs as a result of the factors described above, the pattern of expansion has proven to be similar throughout all countries. Supermarkets are initially established in high-income areas of urban centers. From there they spread to lower income areas within the same city, and then onto other parts of the country which are less urbanized and have lower average household income levels (Stringer et al., 2009). In the first wave countries, and also in some of the second wave countries, supermarkets have already reached middle and low income groups, like the working urban poor. In third wave countries, however, they remain luxury niches for the upper class (Reardon and Timmer, 2007).

In addition to the spatial diffusion of supermarkets, an expansion of product categories can also be observed. In their early stages of development, supermarkets focus on staples and processed goods, offering these products at low prices to attract a broad array of customers and thus competing with traditional grocers' shops (Reardon et al., 2007). By 2002, supermarkets' share of processed/packaged food in the retail market was already 63\% in East Asia and 33\% in Southeast Asia (Pingali, 2006). In advanced stages of development, however, the fresh food segment, which 
includes fish, bakery goods, fresh fruits and vegetables, is becoming increasingly important to supermarkets. However, empirical evidence shows that the supermarkets' share of fresh produce retail is still lower than its share of overall food retail, but is nevertheless increasing (Farina, 2002; Pingali, 2006; Reardon and Berdegué, 2002). In sum, the trends observed nowadays in developing countries mirror the development that took place in the retail sector in the U.S. and Europe a few decades ago.

\section{The importance of fresh fruits and vegetables}

Fresh fruits and vegetables (FFV) are one of the fastest growing agricultural markets in developing countries, and although the share of fresh produce sales as a percentage of total food sales in modern retail markets remains low, this product category is gaining in importance in these markets (World Bank, 2008; Reardon et al., 2010). In addition, horticultural products are considered to be income-boosting alternatives to basic grains for smallholder farmers, and they contribute to increasing employment opportunities (World Bank, 2008). We are therefore focusing our study on the fresh fruits and vegetables sector, and in particular, on fresh vegetables.

For horticultural farmers, supermarkets are not only a new type of market outlet, but they are also quite different from traditional markets. This is reflected in the products they offer as well as their procurement systems. With regard to the products being offered, two aspects need to be mentioned: product variety and product quality. Supermarkets aim to attract consumers by offering a wide variety of products, including exotic products which are not always found on traditional markets. These exotic products are often imported, e.g. apples from New Zealand, by supermarkets in Thailand. However, if climatic conditions and framework conditions are suitable, exotic products can also be produced locally.

As for product quality, supermarkets follow the strategy of implementing private quality and safety standards (Pingali, 2006; Farina, 2002). The incentives for this behavior are twofold: First of all, developing countries often lack public standards. Introducing private standards makes it possible for supermarkets to better coordinate supply chains and to reduce waste resulting from poor quality produce, thus reducing transaction costs and overall costs (Farina, 2002). Second, standards can be reflected in labels which inform consumers about product quality attributes, some of which 
might not be plainly observable. This is one way to differentiate products and compete with traditional markets (Berdegué et al, 2005). Another reason to implement standards is to work towards the fulfillment of the multinational retailers' goal of harmonizing standards between developed countries and developing countries (Reardon and Timmer, 2007). It appears, however, that standards applied in developing countries primarily concern only the products' appearance, i.e. size and color (Reardon et al., 2010).

Supermarkets also implement tremendous changes in procurement systems. First of all, modern retail markets eliminate per store procurement by establishing distribution centers which supply several branches of their retail chain. This increases efficiency by reducing coordination and other transaction costs. Second, supermarkets reduce purchases from wholesale markets and establish their own system of preferred suppliers. Farmers are less often direct suppliers of these markets, but are nevertheless linked through specialized wholesalers or other intermediaries. The latter focus on a small range of products and have the supermarket as their main customer. This results in a reduction of transaction and coordination costs. The shift to these traders is often accompanied by a third aspect: the implementation of contractual arrangements with suppliers. This enables supermarkets to better manage on-time delivery of the right quantity and quality of a product (Reardon et al., 2003). In sum, all changes to procurement systems aim to increase coordination and lower the chain's transaction costs.

\section{Impact of supermarket expansion on smallholder farmers}

The described differences in supermarkets` product offers and procurement systems affect smallholder farmers in various ways. On the one side, we see that supermarkets are an additional market outlet for farmers. Furthermore, when exotic products are introduced to local agriculture, farmers can benefit from a diversification of their product portfolio. Empirical studies also show that supermarkets offer higher financial benefits and can have positive effects on the farm income of smallholder farmers (Hernández et al., 2007; Neven et al., 2009; Stokke, 2009). On the other side, however, supermarkets' additional requirements are considered a barrier, particularly for smallholder farmers. Meeting supermarkets' quality requirements often requires improved technologies, e.g. modern irrigation facilities and/or greenhouse production. 
Due to a variety of reasons, including a lack of both capital and economics of scale, smallholder farmers have difficulties meeting these requirements (Neven et al., 2009; Neven and Reardon, 2008; Henson et al., 2005; Weatherspoon and Reardon, 2003). Furthermore, in dualistic structures, supermarkets prefer to deal with large-scale farmers, because this enables them to have a smaller number of suppliers, thus simplifying supply chain coordination and the monitoring of production practices. In cases where supermarkets are required to buy from smallholder farmers, there tends to be an upper tier of farmers which supplies the supermarkets (Boselie et al., 2003; Bignebat et al., 2009, Huang et. al, 2008).

The changing procurement systems affect the farmers as well. It is difficult for individual smallholder farmers to deliver minimum quantities on fixed dates. Moreover, the changes to the procurement system require new, business-like farm management practices (Neven and Reardon, 2008). While empirical evidence indicates that rich, large-scale farms tend to benefit from the increased demand of FFV in supermarkets (Schwentesius and Manuel, 2002; Berdegué et al., 2005), more case studies are needed to establish a comprehensive assessment as well as generalizations. Moreover, certain aspects are yet to be understood and addressed in the literature, e.g. spillovers into traditional markets as a result of the expansion of modern retail structures. By studying the case of supermarket expansion in Thailand we aim to contribute to the overall picture regarding the implications of food-system transformations and to point out strategies how smallholder farmers can benefit from food market transformations.

\section{Supermarket expansion in Thailand}

Thailand is one of the frontrunners of the second wave countries. In other words, Thailand's supermarket expansion started relatively early and is today in an advanced stage of development. Following the diffusion pattern described above, supermarkets were first established in Bangkok, they then spread to other urban centers and, most recently, branches were opened in rural towns. The majority of supermarket outlets are, however, still located in Bangkok, as we show in chapter 4.

The expansion of supermarkets in Thailand was primarily driven by three main factors: economic growth, which led to growth of the middle class; the new concomitant patterns and purchasing habits described above; and the opening of the countries 
markets in the late 1990s. This third factor, in combination with the economic crisis in South East Asia, led to increased retail sales by multinational chains. In 2007, only two of the five most important retail chains were still Thai-owned (TDRI, 2002; Tokrisna, 2006).

Since the 1990s supermarkets have constantly been gaining importance. This is reflected in the growing number of branches of retail chains as well as in supermarkets' increasing share in all retail trade (TDRI, 2002). Although precise figures for the share of FFV in food sales of modern retail markets are unavailable, the importance of this product category is increasing (Wiboonpongse and Sriboonchitta, 2004). Moreover, Suddeephong (2010) has shown that Bangkok households spend more than $20 \%$ of their expenditures on fresh fruits and vegetables from modern retail markets. Taking into particular consideration that fresh vegetables are produced by a large number of small farmers, it is important to understand how changing market structures for this food segment affect the farming sector.

Surprisingly, there are very few studies which specifically address Thailand, despite the fact that this country is an ideal example for exploring the implications of supermarket expansion on smallholder farmers and rural development (Boselie et al., 2003; Shepherd, 2005; Wiboonpongse and Sriboonchitta, 2004; Vandergeest, 2006). While most of these studies only map the overall trends and call attention to some general issues for smallholder farmers, e.g. the implementation of private standards, the few existing case study examples are merely descriptive. Empirical investigations, which could give more specific insights about the implications of retail market transformations on smallholder farmers, are lacking. With this study we aim to fill this research gap by employing an empirical study focusing on vegetable producing smallholder farmers in Thailand.

\section{Research questions}

Given the research gaps outlined above, this study aims to answer the following research questions:

(1) Which spillover effects can be expected from supermarket expansion and how can smallholder farmers benefit from these? 
(2) How far are changing institutional arrangements between farmers and buyers determinants for the integration of smallholder farmers into modern retail structures?

(3) What are the implications of supermarket expansion for wet markets, which are still the major market outlet for smallholder farmers?

The first research question is addressed in chapter 2. Besides examining effects of supermarket expansion on participating farmers, we also aim to identify spillovers to traditional markets from modern supply chains. We take the example of sweet pepper, which was introduced in Thailand some 10 years ago as a non-traditional vegetable. It was primarily intended for export and upscale domestic supermarkets, but is now traded in many traditional wholesale and retail markets. Building on primary farm survey data, we first examine what factors generally determine farmers' decisions to adopt sweet pepper as a product innovation, with special consideration of adoption dynamics. Furthermore, we assess the impact of sweet pepper adoption on household income and analyze whether the type of marketing channel used - modern or traditional - and/or the timing of adoption affect income.

The third chapter aims to answer the second research question. Previous studies primarily explain the market integration of farmers using farm and farmer characteristics. We follow a different approach and assess the degree to which differences in institutional arrangements between farmers and traders affect the farmers' market channel choice. Using recent data from the same farm survey as well as data from a choice experiment with farmers, we are able to determine which details of institutional arrangements motivate farmers' decisions to participate in particular marketing channels.

The third research question is answered in the fourth chapter. Keeping in mind the increasing importance of fresh fruits and vegetables in modern retail markets, we are especially interested in exploring how well wet markets can compete with modern retail markets. This is achieved by analyzing the competition strategy with regard to the product prices and quality of different retail formats. Based on primary data from a market survey, we compare modern retail markets' and wet markets' observable product quality attributes and prices and then identify their effects.

The fifth chapter of this study contains the conclusions. 


\section{Spillovers from modern supply chains to traditional markets: product innovation and adoption by smallholders ${ }^{3}$}

\subsection{Introduction}

In many developing countries, agricultural and food systems are undergoing a major transformation towards high-value and modern supply chains. In export markets, standards and certification systems are gaining in importance, while domestically, the role of supermarkets and hypermarkets is growing (Reardon et al., 2003; Traill, 2006; Mergenthaler et al., 2009). There is an emerging body of literature analyzing

\footnotetext{
${ }^{3}$ This chapter is published as a journal article in 'Agricultural Economics 41 (2010) 361-371'. The coauthor of the article is Matin Qaim, Prof. of the Department of Agricultural Economics and Rural Development, Georg-August-University of Göttingen, 37037 Göttingen, Germany.
} 
how smallholder farmers can be linked successfully to such modern supply chains. This literature can be broadly divided into three strands. The first strand focuses on the introduction of non-traditional export crops into the small farm sector, including aspects of adoption and household welfare (von Braun et al., 1989; Carletto et al., 1999; Singh, 2002). The second strand includes more recent studies that analyze the impacts of rising food safety and quality standards in export markets on smallholder farmers (e.g., Henson et al., 2005; Asfaw et al., 2009; Maertens and Swinnen, 2009), while the third strand explores the implications of domestic market changes within developing countries resulting from the establishment of super- and hypermarkets (e.g., Berdegué et al., 2006; Neven and Reardon, 2006; Hernández et al., 2007).

This previous research covers a broad range of important issues. However, most of the available studies examine impacts by only comparing participants and nonparticipants in modern supply chains at a certain point in time. This can be a suitable approach to get a first impression, but it fails to capture two relevant facets: First, participation dynamics are not considered. This can mask important effects, as earlier innovators are often able to reap greater benefits. Second, spillovers that modern supply chains may have on traditional markets are ignored, which might lead to an underestimation of the full benefits. For instance, product innovations, say in the form of non-traditional vegetables, are often first introduced in a country through modern supply chains. If the new product suits domestic production and consumption conditions, it might gradually also penetrate traditional markets, where it can generate additional benefits, including for farmers that do not participate themselves in modern supply chains.

We contribute to the literature by analyzing such aspects for the case of sweet pepper in Thailand. Sweet pepper was introduced in Thailand some 10 years ago as a nontraditional vegetable, mainly meant for exports and upscale domestic supermarkets. Yet, over time the product gained wider popularity among domestic consumers, so that it is now traded also in more traditional wholesale and retail markets. Rapidly rising living standards and urbanization tendencies in Thailand have spurred numerous product innovations in the recent past; similar trends are also observable in many other middle-income countries (Swinnen, 2007). Building on primary survey data, we analyze three main aspects. First, we examine what factors generally determine 
farmers' decisions to adopt sweet pepper as a product innovation. This is done by estimating probit models, whereby the timing of adoption is explicitly considered. Second, by employing a duration model, we look at adoption dynamics and identify factors that favor early adoption. And third, controlling for other factors and taking account of possible non-random selection issues, we estimate a treatment effect model to assess the impact of sweet pepper adoption on household income. We also analyze whether the type of marketing channel supplied - modern or traditional and the timing of adoption matter for the income effect.

The paper proceeds as follows. The next section gives some more background about sweet pepper production in Thailand, the particular study region, and the empirical database. Subsequently, the econometric adoption models are developed, estimated and discussed in the third and fourth section. The fifth section provides the results of the impact analysis, and the last section concludes.

\subsection{Background on sweet pepper cultivation in Thailand and database}

\subsubsection{Sweet pepper cultivation and marketing channels}

Sweet pepper was introduced in Thailand in 1999 by a Dutch company. Because of climatic conditions, the northern upland areas were the primary target regions, especially those near the city of Chiang Mai, where infrastructure and market access conditions were relatively favorable. In particular, the company chose the Mae Sa watershed (Chiang Mai Province), where farmers were contracted to produce red and green sweet pepper in greenhouses, using hydroponics systems that make cultivation independent from soil quality conditions. A major advantage from the company viewpoint was that farmers in the Mae Sa watershed were already familiar with cash crop production. Previously, they had mainly grown cut flowers in greenhouses, complemented by different vegetables or rice. However, sweet pepper cultivation is more labor and input intensive than flower production. It is also associated with higher capital investments, since more sophisticated greenhouses are required. Since farms in the watershed are predominantly small-scale, with an average farm size of 0.7 hectares, the company initially provided credit, private extension, and certain inputs to contracted farmers. 
The Dutch company purchases sweet peppers from farmers for exports to Taiwan and China, as well as for sales in modern domestic supply chains. Until 2001, only few farmers had adopted sweet pepper, but afterwards adoption rates increased. Gradually, additional companies entered the sweet pepper market, mostly supplying domestic super- and hypermarkets. These companies usually have their preferred farmers in the Mae Sa watershed from whom they buy via formal or informal agreements. A special marketing channel for local farmers is the so-called Royal Project, which started to deal with sweet pepper in 2002. The Royal Project is a subsidized initiative by the King of Thailand to support disadvantaged farmers in the upland areas and offer alternatives to opium production, which was widespread in the 1970s and $80 \mathrm{~s}$. The Project sells vegetables and other agricultural products in upscale outlets under its own brand name, which Thai consumers recognize as being of very high quality. However, only hill tribe farmers, who make up a relatively small part of the population in the Mae Sa watershed, have access to Royal Project marketing channels. In addition to these modern supply chains, traditional village traders increasingly started to deal with sweet pepper through spot-market transactions. They mostly supply regular vegetable wholesale and retail markets in Chiang Mai and Bangkok.

\subsubsection{Database}

For our empirical study, we conducted a survey of 308 farmers in the Mae Sa watershed in northern Thailand. This watershed is where domestic sweet pepper cultivation had started in 1999, and it is still the main production area for sweet pepper in Thailand. The survey was conducted between May and July 2007. The Mae Sa watershed consists of 22 villages in total, but sweet pepper is cultivated in only 9 villages. Within these 9 villages, all sweet pepper adopters (246 farmers) and 62 randomly selected non-adopters (in total 669 non-adopters live in the 9 villages) were interviewed, using a structured questionnaire especially designed for this research. To be able to analyze adoption dynamics, we asked farmers in which year they had started farming in general and sweet pepper cultivation in particular. Likewise, for time-variant variables like agricultural assets, farm size or non-farm occupation we collected data not only for the status quo in 2007, but also captured changes that occurred in the past since 1999. 
Figure 1 shows that it took several years until sweet pepper was adopted more widely amongst farmers in the watershed. Considering marketing channels, in the first two years, all adopting farmers sold their sweet pepper to companies under contract, since this was the only available option. The role of the Royal Project increased over time, but the overall market share remains relatively small. Today, traditional village traders constitute the most important marketing channel, and it appears that their entrance into the sweet pepper business was an important trigger for many farmers to adopt this product innovation.

\section{Figure 1: Sweet pepper adoption and the role of different marketing channels}

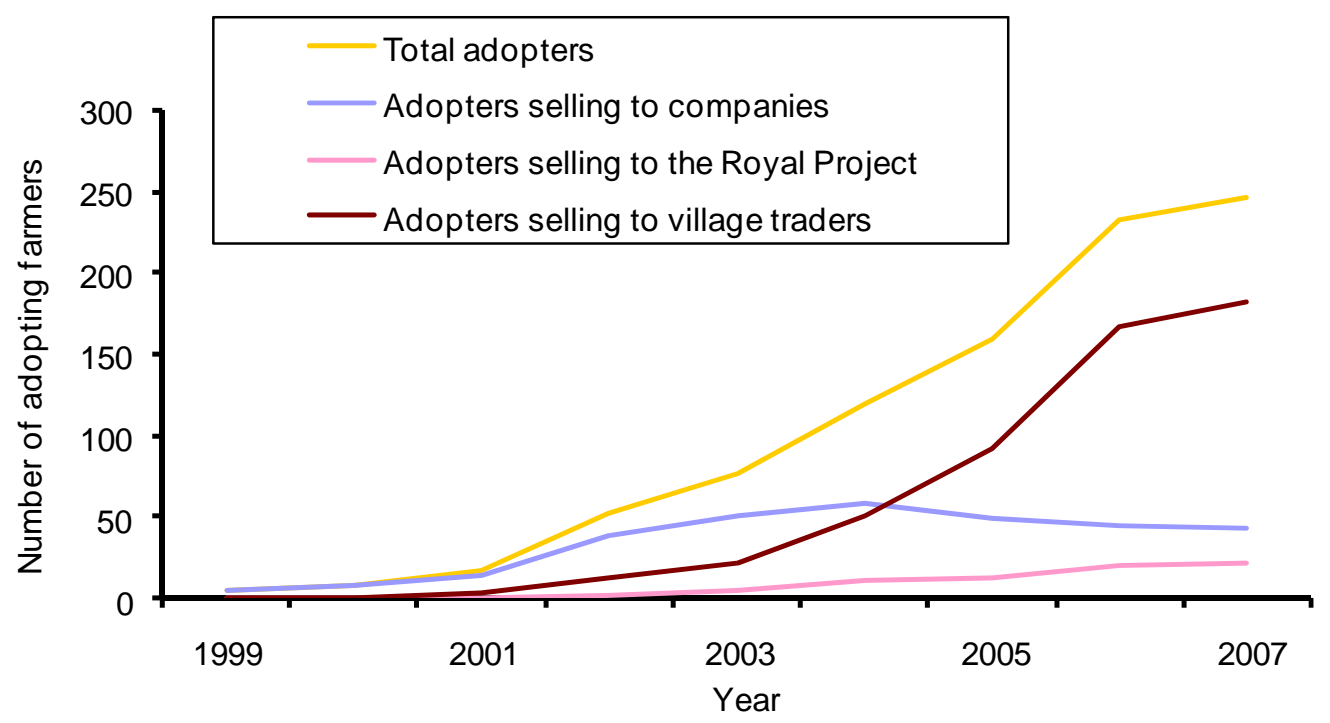

Source: Own calculations

Spot-market transactions with village traders are more flexible and less formal than with companies, conditions that many local farmers seem to prefer. And, now that sweet pepper and the production technology have been established in the region, the inputs required can be obtained from different open market suppliers. That is, company contracts are not a precondition for producing sweet pepper anymore. These patterns confirm that product innovations might initially be introduced through modern supply chains, but they also demonstrate that spillovers to traditional markets occur with a certain time lag, if the innovation suits local production and consumption conditions on a wider scale. 


\subsection{Explaining farmers adoption decisions}

\subsubsection{Comparison of adopters and non-adopters}

Adoption of a new product confronts a farmer with new conditions. The more a farmer is able to meet these conditions, the more likely the adoption decision will be positive. Possible adoption constraints can be distinguished into three categories: personal constraints, farm and household constraints, and contextual constraints. The first category covers characteristics like age and education, the second factors like farm size, land title and off-farm occupation, while the third comprises aspects like road conditions and access to extension services. Earlier studies show that adoption constraints differ according to the particular innovation a farmer is confronted with and the general framework conditions (e.g., Feder et al., 1985; von Braun et al., 1989). Farm size, for example, can play an important role, especially in settings with dual farm structures. Access to capital is especially relevant when the new crop requires increased input use or additional equipment, whereas family labor endowment becomes important when crops require careful treatment and machinery cannot be used (Takane, 2004). When explaining farmers' adoption behavior, such factors have to be considered.

We are interested in explaining the farmers' behavior with respect to sweet pepper adoption in general, but, since the impact of adoption often also depends on the factor time, we attempt to analyze adoption dynamics, too. For this purpose, the group of adopters is disaggregated into three sub-groups, each comprising around one third of the total number of adopters. The first sub-group covers the early adopters, who adopted sweet pepper between 1999 and 2003. The second sub-group includes those that adopted in 2004 or 2005, which is also the time when village traders had entered the market, while the third sub-group consists of the laggards, who adopted sweet pepper between 2006 and 2007. In Table 1, we compare descriptive statistics for the total group of adopters and for each of the sub-groups with the group of non-adopters in the respective time period. There are a few individuals in the sample that only started farming recently; they are not included in comparisons referring to earlier time periods. 
Table 1: Descriptive statistics for different groups of adopters and non-adopters

\begin{tabular}{lcccccccc}
\hline & $\begin{array}{c}\text { Non- } \\
\text { adopter }\end{array}$ & $\begin{array}{c}\text { Adopter } \\
\text { Variables }\end{array}$ & $\begin{array}{c}\text { Non- } \\
\text { adopter }\end{array}$ & $\begin{array}{c}\text { Adopter } \\
1999-\end{array}$ & $\begin{array}{c}\text { Non- } \\
\text { adopter }\end{array}$ & $\begin{array}{c}\text { Adopter } \\
2006-\end{array}$ & $\begin{array}{c}\text { Adopter } \\
1999-\end{array}$ \\
& $1999-$ & 2003 & $1999-$ & $200-$ & $1999-$ & 2007 & 2007 \\
& 2003 & & 2005 & 2005 & 2007 & & \\
& $(\mathrm{~N}=189)$ & $(\mathrm{N}=76)$ & $(\mathrm{N}=131)$ & $(\mathrm{N}=81)$ & $(\mathrm{N}=62)$ & $(\mathrm{N}=88)$ & $(\mathrm{N}=246)$ \\
\hline
\end{tabular}

Characteristics of the person responsible for farming decisions

$\begin{array}{lccccccc}\text { Female (\%) } & 40.7 & 47.4 & 42.8 & 40.7 & 33.9 & 50.0^{* *} & 46.1^{*} \\ & 41.0 & 37.0^{* * *} & 42.8 & 39.9^{* *} & 47.6 & 41.2^{* * *} & 39.5^{* * *} \\ \text { Age in years } & (10.1) & (8.0) & (10.7) & (10.1) & (11.6) & (9.7) & (9.5) \\ & 5.8 & 7.2^{* * *} & 5.6 & 6.8^{* * *} & 4.6 & 6.7 * * * & 6.7 * * * \\ \text { Education in } & (2.9) & (3.7) & (2.9) & (3.3) & (2.7) & (3.0) & (3.3) \\ \text { years } & & & & & \end{array}$

Farm and household characteristics

\begin{tabular}{|c|c|c|c|c|c|c|c|}
\hline $\begin{array}{l}\text { Land owned in } \\
\text { rai }^{\text {a }}\end{array}$ & $\begin{array}{l}4.2 \\
(6.4)\end{array}$ & $\begin{array}{l}4.0 \\
(6.9)\end{array}$ & $\begin{array}{l}4.7 \\
(7.3)\end{array}$ & $\begin{array}{l}3.1^{*} \\
(3.6)\end{array}$ & $\begin{array}{c}3.8 \\
(5.4)\end{array}$ & $\begin{array}{l}4.5 \\
(7.8)\end{array}$ & $\begin{array}{l}3.9 \\
(6.4)\end{array}$ \\
\hline $\begin{array}{l}\text { Area cultivated } \\
\text { in rai }\end{array}$ & $\begin{array}{l}3.9 \\
(7.0)\end{array}$ & $\begin{array}{c}4.6 \\
(14.1)\end{array}$ & $\begin{array}{l}4.5 \\
(8.2)\end{array}$ & $\begin{array}{c}2.7 * * \\
(2.7)\end{array}$ & $\begin{array}{l}3.8 \\
(5.0)\end{array}$ & $\begin{array}{l}4.3 \\
(9.3)\end{array}$ & $\begin{array}{l}3.9 \\
(9.8)\end{array}$ \\
\hline $\begin{array}{l}\text { Area sweet } \\
\text { pepper in rai }\end{array}$ & -- & $\begin{array}{c}1.6 \\
(1.0)\end{array}$ & -- & $\begin{array}{c}1.4 \\
(1.1)\end{array}$ & -- & $\begin{array}{c}1.1 \\
(1.1)\end{array}$ & $\begin{array}{l}1.3 \\
(1.1)\end{array}$ \\
\hline Land title $(\%)$ & 72.0 & $88.2 * * *$ & 65.7 & $84.0 * * *$ & 58.1 & $76.1 * *$ & $82.5 * * *$ \\
\hline $\begin{array}{l}\text { Pick-up truck } \\
(\%)\end{array}$ & 38.1 & $52.6^{* *}$ & 38.2 & 43.2 & 29 & $53.4 * * *$ & $49.8 * * *$ \\
\hline $\begin{array}{l}\text { Off-farm occu- } \\
\text { pation }(\%)\end{array}$ & 47.1 & $31.6^{* *}$ & 56.5 & $35.8 * * *$ & 58.1 & 51.1 & $40.0 * * *$ \\
\hline
\end{tabular}

\section{Contextual characteristics}

Member in a farm group (\%)

$$
5.8 \quad 2.6
$$

4.9

$6.5 \quad 10.2$

5.3

Extension contact (\%)

$$
10.129 * * *
$$

9.16

14.81

3.2

$11.4^{*} \quad 18.0 * * *$

Good road conditions (\%)

\section{$\begin{array}{lllll}63.0 & 96.1 * * * & 55 & 82.7 * * * & 54.8\end{array}$}

$59.178 .4 * * *$

\footnotetext{
Notes: Mean values are shown. For continuous variables, standard deviations are shown in parentheses. ${ }^{\mathrm{a}}$ One rai equals 0.16 hectares.

$*, * *, * * *$ differences are significant at the $10 \%, 5 \%$, and $1 \%$ level, respectively. Significant levels were obtained from a chi2-test and t-test, respectively. Differences are always tested between adopters and non-adopters in a particular time period. The total group of adopters is tested against the total group of non-adopters in 1999-2007.

Source: Own calculations
} 
The comparisons suggest that adopters are more often female and are younger and better educated than non-adopters. Among the farm and household characteristics, having a land title and owning a pick-up truck are variables that are positively correlated with sweet pepper adoption. On the other hand, fewer farm households with off-farm occupations are among the adopters. In terms of the contextual characteristics, contacts to official public extension agents and road conditions are significantly different between adopters and non-adopters. Road conditions are evaluated by the average time it takes to reach the city of Chiang Mai. According to this variable, households are sub-divided into those with good, medium and bad road conditions, each group including three of the 9 villages. The magnitude of the differences and the significance levels partly vary over time. Some of the variables, like extension and road conditions, are particularly important during the early stages of adoption, while others, like education and land titles, remain important over the entire period. We further investigate these differences in the following econometric analyses.

\subsubsection{Specification of probit adoption models}

Differences in mean values, as analyzed in Table 1, should not be over-interpreted, since possible confounding factors are not controlled for. This requires appropriate regression models. For the purpose of explaining adoption behavior, estimation of probit models is a common approach (McFadden, 1980; Gregg, 2009). Table 2 shows results of different probit models, where sweet pepper adoption is defined as a binary variable. Model 1 estimates adoption behavior using the entire group of adopters, that is, the dependent variable takes a value of 1 if sweet pepper was adopted until 2007 and is 0 otherwise. The covariates include the farm, household, and contextual characteristics discussed above, plus other variables that are commonly used in the innovation adoption literature (Feder et al., 1985; Abdulai and Huffman, 2005). Models 2 to 4 have the same specification, but they are run with different sub-samples to capture changes over time. Model 2 refers to the early stage of adoption, that is, all households that adopted until 2003 are considered as adopters, and all other households as non-adopters. Model 3 refers to adopters in 2004 and 2005, while model 4 explains adoption in 2006 and 2007. In these latter two models, farmers who had adopted before the respective time period are dropped. 
To avoid statistical and interpretation problems, time-variant variables need special treatment. For adopters, we set all values back to the individual time of adoption, whereas for non-adopters we use the values at the end of the respective time period. These adjustments are, as mentioned above, based on recall data that we elicited during the survey. The alignment of time-variant variables also allows us to address potential problems of reverse causality. For instance, agricultural assets might increase the probability of sweet pepper adoption, but, on the other hand, adoption might also entail asset accumulation. Indeed, when estimating our models without taking account of time-variant factors (i.e., assuming 2007 values for all variables), the estimates for agricultural assets turned out to be positive and significant, while they are not significant in any of our improved specifications.

\subsubsection{Estimation results}

The estimation results for the four models are shown in Table 2. The coefficients in model 1 largely confirm the results from the descriptive statistics. Age negatively influences adoption behavior, whereas education has a positive impact. Given the complexity of sweet pepper cultivation (i.e., greenhouses with hydroponics systems), it is understandable that younger and better-educated farmers are more likely to adopt the innovation. This is a common finding in the agricultural innovation adoption literature (e.g., Dadi et al., 2004; Abdulai and Huffman, 2005; D’Emden et al., 2008; Rahman et al., 2009).

Another widely discussed variable in the adoption literature is farm size. As smallholder farmers are among the poorest households in developing countries, empirical studies often pay special attention to this particular group. Whereas some innovations and framework conditions favor adoption by larger farms, the opposite holds true in other situations (e.g., Matuschke and Qaim 2008). However, interpretations should be done with care, as farm size is often correlated with or even used as a proxy for other factors like wealth, access to credit, or risk aversion (Feder et al., 1985; Carletto et al., 2007; Reardon et al., 2009). In our case, farm size has a positive but very small effect on adoption. This is plausible, as most farmers in the watershed are smallholders anyway, so that substantial economies of scale can hardly be observed. 
Table 2: Determinants of sweet pepper adoption

\begin{tabular}{|c|c|c|c|c|}
\hline Variable & $\begin{array}{c}\text { Model 1 } \\
\text { (adoption } \\
\text { 1999-2007) } \\
\end{array}$ & $\begin{array}{c}\text { Model } 2 \\
\text { (adoption } \\
\text { 1999-2003) }\end{array}$ & $\begin{array}{c}\text { Model 3 } \\
\text { (adoption } \\
\text { 2004-2005) }\end{array}$ & $\begin{array}{c}\text { Model } 4 \\
\text { (adoption } \\
\text { 2006-2007) } \\
\end{array}$ \\
\hline Education (years) & $\begin{array}{c}0.02 * * * \\
(0.01)\end{array}$ & $\begin{array}{c}0.02 * * \\
(0.01)\end{array}$ & $\begin{array}{c}0.04 * * \\
(0.02)\end{array}$ & $\begin{array}{c}0.05 * * \\
(0.02)\end{array}$ \\
\hline Female (dummy) & $\begin{array}{c}0.04 \\
(0.03)\end{array}$ & $\begin{array}{l}-0.02 \\
(0.06)\end{array}$ & $\begin{array}{l}-0.13^{*} \\
(0.07)\end{array}$ & $\begin{array}{c}0.13 \\
(0.09)\end{array}$ \\
\hline Age (years) & $\begin{array}{c}-5 \mathrm{E}-03 * * * \\
(2 \mathrm{E}-03)\end{array}$ & $\begin{array}{c}-6 \mathrm{E}-03 * \\
(3 \mathrm{E}-03)\end{array}$ & $\begin{array}{l}-1 \mathrm{E}-05 \\
(4 \mathrm{E}-03)\end{array}$ & $\begin{array}{c}-1 \mathrm{E}-02 * * \\
(6 \mathrm{E}-03)\end{array}$ \\
\hline Land owned (rai) & $\begin{array}{c}7 \mathrm{E}-03 * * \\
(3 \mathrm{E}-03)\end{array}$ & $\begin{array}{l}7 \mathrm{E}-03 \\
(4 \mathrm{E}-03)\end{array}$ & $\begin{array}{l}-4 \mathrm{E}-03 \\
(7 \mathrm{E}-03)\end{array}$ & $\begin{array}{l}2 \mathrm{E}-01 * * * \\
(7 \mathrm{E}-02)\end{array}$ \\
\hline Land title (dummy) & $\begin{array}{c}0.04 \\
(0.04)\end{array}$ & $\begin{array}{c}0.01 \\
(0.08)\end{array}$ & $\begin{array}{l}0.06 \\
(0.10)\end{array}$ & $\begin{array}{l}0.09 \\
(0.11)\end{array}$ \\
\hline Family labor endowment & $\begin{array}{l}-0.01 \\
(0.01)\end{array}$ & $\begin{array}{l}-0.02 \\
(0.03)\end{array}$ & $\begin{array}{c}0.04 \\
(0.03)\end{array}$ & $\begin{array}{c}-0.06^{*} \\
(0.04)\end{array}$ \\
\hline $\begin{array}{l}\text { Off-farm occupation } \\
\text { (dummy) }\end{array}$ & $\begin{array}{c}-0.19 * * * \\
(0.05)\end{array}$ & $\begin{array}{c}-0.18 * * * \\
(0.05)\end{array}$ & $\begin{array}{c}-0.28 * * * \\
(0.07)\end{array}$ & $\begin{array}{c}-0.22 * * \\
(0.09)\end{array}$ \\
\hline $\begin{array}{l}\text { Info source trader/dealer }{ }^{\mathrm{a}} \\
\text { (dummy) }\end{array}$ & $\begin{array}{c}-0.09 * * \\
(0.03)\end{array}$ & $\begin{array}{l}0.01 \\
(0.06)\end{array}$ & $\begin{array}{l}0.04 \\
(0.09)\end{array}$ & $\begin{array}{c}0.03 \\
(0.10)\end{array}$ \\
\hline $\begin{array}{l}\text { Medium road conditions }{ }^{b} \\
\text { (dummy) }\end{array}$ & $\begin{array}{c}-0.10^{*} \\
(0.08)\end{array}$ & $\begin{array}{l}-0.25 * * * \\
(0.04)\end{array}$ & $\begin{array}{l}-0.25 * * * \\
\quad(0.07)\end{array}$ & $\begin{array}{l}-0.04 \\
(0.13)\end{array}$ \\
\hline $\begin{array}{l}\text { Bad road conditions } \\
\text { (dummy) }\end{array}$ & $\begin{array}{c}-0.35 * * * \\
(0.12)\end{array}$ & $\begin{array}{c}-0.27 * * * \\
(0.04)\end{array}$ & $\begin{array}{c}-0.37 * * * \\
(0.07)\end{array}$ & $\begin{array}{c}-0.26^{*} \\
(0.15)\end{array}$ \\
\hline $\begin{array}{l}\text { Member in a farm group } \\
\text { (dummy) }\end{array}$ & $\begin{array}{c}0.01 \\
(0.06)\end{array}$ & $\begin{array}{l}-0.14 \\
(0.07)\end{array}$ & $\begin{array}{c}-0.24 * * \\
(0.08)\end{array}$ & $\begin{array}{c}0.17 \\
(0.11)\end{array}$ \\
\hline Extension contact (dummy) & $\begin{array}{c}0.11 * * * \\
(0.03)\end{array}$ & $\begin{array}{c}0.34 * * * \\
(0.10)\end{array}$ & $\begin{array}{l}0.19^{*} \\
(0.11)\end{array}$ & $\begin{array}{c}0.36^{* * * *} \\
(0.07)\end{array}$ \\
\hline $\begin{array}{l}\text { Value of non-land agricult. } \\
\text { assets ( } 100 \text { thsd. Baht) }\end{array}$ & $\begin{array}{l}-2 \mathrm{E}-03 \\
(2 \mathrm{E}-02)\end{array}$ & $\begin{array}{l}-0.03 \\
(0.05)\end{array}$ & $\begin{array}{l}-0.06 \\
(0.08)\end{array}$ & $\begin{array}{l}-0.05 \\
(0.07)\end{array}$ \\
\hline $\begin{array}{l}\text { Value of other assets } \\
\text { (100 thsd. Baht) }\end{array}$ & $\begin{array}{c}0.03 \\
(0.03)\end{array}$ & $\begin{array}{l}-0.03 \\
(0.04)\end{array}$ & $\begin{array}{l}-0.11 \\
(0.07)\end{array}$ & $\begin{array}{l}0.14^{*} \\
(0.08)\end{array}$ \\
\hline Pick-up truck (dummy) & $\begin{array}{c}0.13 * * * \\
(0.04)\end{array}$ & $\begin{array}{c}0.13 * * \\
(0.06)\end{array}$ & $\begin{array}{l}0.13 \\
(0.08)\end{array}$ & $\begin{array}{c}0.34 * * * \\
(0.09)\end{array}$ \\
\hline Number of observations & 307 & 265 & 212 & 150 \\
\hline Wald chi2 & $77.90 * * *$ & $63.62 * * *$ & $48.35 * * *$ & $47.37 * * *$ \\
\hline Pseudo $\mathrm{R}^{2}$ & 0.37 & 0.28 & 0.22 & 0.29 \\
\hline
\end{tabular}

Notes: Coefficient estimates are marginal effects. Robust standard errors are shown in parentheses.

$*, * *, * * *$ significant at the $10 \%, 5 \%$, and $1 \%$ level, respectively. ${ }^{\mathrm{a}}$ The reference variable is farmers that have persons other than the trader/input dealer as a main source of information. ${ }^{b}$ The reference variable is good road conditions.

Source: Own calculations 
Although sweet pepper cultivation is quite labor intensive, the family labor endowment does not seem to influence adoption significantly. Yet it is also important to consider whether there are alternative income sources for family members that could potentially prevent them from spending substantial time in farming. Indeed, Table 2 shows that households with off-farm occupation are less likely to adopt sweet pepper, suggesting that there is a certain competition for labor within households. A similar result was also reported by Hernández et al. (2007) in Guatemala.

Considering the contextual variables, medium and bad road conditions reduce the probability of adoption, whereas contacts with agricultural extension agents and ownership of a pick-up truck increase the probability. In other words, market and information accessibility have a positive influence on adoption, which is as expected and was shown in other studies as well (Randela et al., 2008; Gregg, 2009; Maertens and Swinnen, 2009). But also the source of information matters. If traders and input dealers are the primary source of information for a farmer on production and marketing aspects, the likelihood of sweet pepper adoption is reduced. This is similar to findings by Burton et al. (2003) in a different context. In the local setting in Thailand, traditional traders and input dealers do not seem to be important multipliers of information related to sweet pepper, which is plausible because the product innovation was initially introduced through other channels. The reference for the trader/dealer dummy is farmers that have other persons - like neighboring farmers or village heads - as an important source of information. This suggests that informal social networks might also play an important role for innovation adoption, which was shown more explicitly by Matuschke and Qaim (2009) among smallholders in India. Models 2 to 4, which analyze the effects during different stages of adoption, give additional insights. Some of the variables, such as education and off-farm occupation, have a fairly consistent influence on adoption during all periods. Other variables, however, show notable differences between the models. For medium and bad road conditions, the effects on the probability of sweet pepper adoption seem to decline over time. That is, good road conditions matter especially during the early adoption stages, which makes sense. As mentioned above, specialized companies were initially the only available marketing channel for sweet pepper in Thailand; these companies primarily contracted farmers in easily accessible locations, in order 
to limit transaction costs associated with extension and monitoring. However, once information about sweet pepper production became more widely available, and traditional traders entered the market, some of the initial constraints have lost in importance.

Trends observed for the coefficients of age, pick-up truck and extension show a somewhat different picture. Contact to a public agricultural extension agent and ownership of a pick-up truck positively influence adoption behavior in an early and late stage of adoption, whereas there is no significant effect in the years in-between. The same is true for age, with younger farmers being more likely to adopt in the first and in the last model. This pattern reflects a change in market and marketing conditions as well. Whereas the spread of information and establishment of traditional traders offered better framework conditions for sweet pepper adoption, dissolving some of the initial constraints, increasing numbers of adopters in more recent years entail occasional oversupplies and higher price volatility and market risk. Under these new conditions, some of the early adoption constraints seem to re-gain in importance. As sweet pepper is only a niche product in Thailand, market prices respond immediately to fluctuating supplies.

\subsection{Explaining adoption dynamics}

\subsubsection{Background on duration models}

Standard adoption models, like the ones estimated above, can only identify factors that influence an individual's decision to adopt or reject an innovation. They cannot properly explain the individual timing of an adoption decision, meaning the time a farmer takes until he/she adopts an innovation. Our approach of categorizing adopters and estimating models at different points in time may capture some of the dynamics, but the models themselves remain static nonetheless. Also within adopter categories, heterogeneity in the time of adoption is observed. Moreover, certain farmers that

only started farming some time during the period of observation cannot easily be categorized by standard static adoption models. To better understand possible adoption constraints and the role they play over time, use of dynamic models is instructive. One promising approach is the employment of duration models (Carletto et al., 1999; Burton et al., 2003; Fuglie and Kascak, 2003; Abdulai and Huffman, 2005; 
Matuschke and Qaim, 2008). Duration models explicitly explain the adoption spell, that is, they help identify factors that have a significant effect on the time it takes an individual to adopt an innovation.

The basic idea of a duration model is to estimate the probability that an individual changes, at the beginning of time period $t$, its position from one stage (non-adoption) to another (adoption), given that the individual has not entered that stage until the beginning of $t$. This probability is reflected by the hazard function, which can be thought of as the continuous time version of a sequence of conditional probabilities (Burton et al., 2003). In innovation adoption studies, the hazard function therefore represents the probability that a farmer adopts the innovation at time $t$, conditioned on the fact that the farmer has not adopted the innovation before $t$ (Dadi et al., 2004). The hazard rate that the individual faces is a function of the baseline hazard and a vector of variables that shifts the hazard multiplicatively.

The baseline hazard can be described by different distribution functions - such as the Weibull, exponential or Gompertz - which vary with respect to the course of adoption; the choice of the most suitable functional form is an empirical problem. A good indicator is the Akaike information criterion (AIC), which should be as low as possible (Cleves et al., 2002). For parametric duration models, the AIC is defined as AIC $=-2 \ln \mathrm{L}+2(\mathrm{k}+\mathrm{c})$. The term $-2 \ln \mathrm{L}$ is the log-likelihood value of the model, $\mathrm{k}$ equals the number of independent variables, and $\mathrm{c}$ is the number of model-specific distribution parameters. The latter is equal to one for the exponential distribution and equal to two for the Weibull and Gompertz distribution. Once an appropriate parameterization is selected, estimation follows maximum-likelihood principles (Greene, 2003).

\subsubsection{Specification of the duration model}

In our case, the innovation is sweet pepper production and the adoption spell is measured in years (1999 until 2007). We set up our data in a discrete time fashion in which each farmer is represented by one to multiple rows according to the number of years it took him/her to adopt (one row for every year of the adoption spell). For farmers who started farming before 1999, when sweet pepper production was introduced, the adoption spell comprises the time between 1999 and the year of adoption. For farmers who started farming later than 1999, the adoption spell is the time from the start of the farming business until the time of adoption. For the baseline hazard, 
using the AIC, we chose a parametric model with a Gompertz distribution. This implies that the hazard rate is either exponentially increasing or decreasing with time. For model estimation, we include 245 farmers who adopted sweet pepper and 62 farmers who did not. For the latter, the adoption spell is not completed as adoption did not take place yet. In this case, the observations are right-censored, indicating that the process is ongoing (Cleves et al., 2002; Burton et al., 2003). The dependent variable is sweet pepper adoption. It equals 0 in all years where sweet pepper was not adopted and 1 in the year of adoption. The explanatory variables are the same as in the probit models above. However, the time-variant variables are included in a more precise manner. Instead of setting the value of a variable back to a certain point in time, duration models allow us to specify the value of a variable for each year of the observation period. The time-variant variables in our model are age, family labor endowment, off-farm occupation, membership in a farm group, ownership of a pickup truck, value of agricultural assets and value of non-agricultural assets.

\subsubsection{Estimation results}

Table 3 displays the estimation results of the duration model. The coefficients are interpreted as effects on the hazard rate of adoption. A positive coefficient has a positive impact on the hazard rate, that is, it speeds up the adoption process and vice versa. Table 3 also shows hazard ratios calculated from the coefficients. A ratio bigger/smaller than one speeds up/slows down the adoption process; subtracting 1 from the hazard ratio results in the marginal effect of the variable on the hazard rate of adoption. The estimates show that education speeds up adoption significantly. This is consistent with findings from previous duration analyses with respect to other agricultural innovations (Fuglie and Kascak, 2003; Abdulai and Huffman, 2005; Matuschke and Qaim, 2008). One year of additional education increases the hazard rate of adoption by $12 \%$. In contrast, age has a negative impact; an increase by one year decreases the adoption hazard by $2 \%$. Looking at farm characteristics we find that land title is more important than size of land owned. The first increases the hazard rate of adoption by $36 \%$, whereas the latter does not show any significant effect at all. This is not surprising. Sweet pepper cultivation is associated with longer-term investments in greenhouse facilities. Holding a land title reduces uncertainty, improves access to formal credit and allows farmers to take a longer planning horizon. 
Table 3: Parametric estimation of the hazard rate of adoption

\begin{tabular}{|c|c|c|c|}
\hline Variable & Coefficient & Standard error & Hazard ratio $^{d}$ \\
\hline Education (years) & $0.11 * * *$ & 0.01 & $1.12 * * *$ \\
\hline Female (dummy) & -0.02 & 0.07 & 0.98 \\
\hline Age (years) & $-0.03 * * *$ & $3 \mathrm{E}-03$ & $0.98 * * *$ \\
\hline Land owned (rai) & 0.05 & 0.04 & 1.06 \\
\hline Land title (dummy) & $0.31 * * *$ & 0.08 & $1.36^{* * *}$ \\
\hline Family labor endowment & $1 \mathrm{E}-05$ & 0.03 & 1.00 \\
\hline Off-farm occupation (dummy) & $-0.61 * * *$ & 0.07 & $0.54 * * *$ \\
\hline $\begin{array}{l}\text { Info source trader/dealer }{ }^{\mathrm{a}} \\
\text { (dummy) }\end{array}$ & $-0.48 * * *$ & 0.06 & $0.62 * * *$ \\
\hline $\begin{array}{l}\text { Medium road conditions } \\
\text { (dummy) }\end{array}$ & $-0.67 * * *$ & 0.08 & $0.51 * * *$ \\
\hline Bad road conditions ${ }^{\mathrm{b}}$ (dummy) & $-0.96 * * *$ & 0.11 & $0.38 * * *$ \\
\hline $\begin{array}{l}\text { Member in a farm group } \\
\text { (dummy) }\end{array}$ & $0.51 * * *$ & 0.08 & $1.67 * * *$ \\
\hline Extension contact (dummy) & $0.75 * * *$ & 0.09 & $2.11 * * *$ \\
\hline $\begin{array}{l}\text { Value of non-land agricult. } \\
\text { assets (100 thsd. Baht) }\end{array}$ & -0.09 & 0.06 & 0.91 \\
\hline $\begin{array}{l}\text { Value of other assets (100 thsd. } \\
\text { Baht) }\end{array}$ & $0.11 * * *$ & 0.03 & $1.11 * * *$ \\
\hline Pick-up truck (dummy) & $0.55 * * *$ & 0.07 & $1.74 * * *$ \\
\hline Constant & $-4.48 * * *$ & 0.22 & -- \\
\hline $\mathrm{Gamma}^{\mathrm{c}}$ & $0.52 * * *$ & 0.02 & $0.52 * * *$ \\
\hline Log-likelihood & -970.16 & & -970.16 \\
\hline
\end{tabular}

Notes: $*, * *, * * *$ significant at the $10 \%, 5 \%$, and $1 \%$ level, respectively. Standard errors are robust. a The reference variable is farmers that have persons other than the trader/input dealer as a main sources of information.

$\mathrm{b}$ The reference variable is good road conditions.

c The positive value for gamma indicates that the hazard rate is exponentially increasing.

$\mathrm{d}$ The hazard ratio is calculated as $\exp$ (coefficient).

Source: Own calculations 
Based on the probit results above and also the findings from other studies (Burton et al., 2003; Matuschke and Qaim, 2008), we expect access to markets to have a significant effect on sweet pepper adoption. Indeed, unfavorable road conditions slow down the adoption process. Compared to good road conditions, medium and bad road conditions decrease the adoption hazard by $49 \%$ and $62 \%$, respectively. In a similar fashion, ownership of a pick-up truck increases the adoption hazard. The large coefficient indicates that pick-up ownership is a particularly important variable. Especially in the first years, when there were no alternative marketing channels, adopting farmers had to transport sweet peppers to the pack house of the Dutch company themselves.

While the important role of information was already apparent in the probit models, it comes out even more clearly here. Contact with extension agents has the largest positive effect on the speed of adoption, but also more informal information exchange through farmer groups speeds up sweet pepper adoption significantly. By contrast, farmers that mainly rely on traders or input dealers as sources of information have adopted much more slowly. This makes sense, as traditional village traders themselves entered the sweet pepper market only with a time lag of several years.

Contrary to Carletto et al. (2007) we find that non-land agricultural assets do not affect the speed of adoption, while non-agricultural assets do. Previous investments in agriculture are not important, because the hydroponics technology for sweet pepper is quite special, so that existing equipment is only of limited use. In contrast, a higher value of non-agricultural assets, which is an indicator of household wealth, speeds up the adoption process significantly.

\subsection{Impact of sweet pepper adoption}

\subsubsection{Specification of the income model}

In addition to explaining adoption, we are interested in the impact of sweet pepper cultivation on income. Usually, farmers only adopt an innovation if it is profitable for them, so that the effect on farm income should be positive (Feder et al., 1985). However, in order to be able to also capture indirect effects and potential resource reallocations within households, we analyze the impact on total household income rather than farm income alone. In the survey, income data were collected in a disaggregate 
fashion, including all agricultural and non-agricultural activities of all household members over a 12-months period. In our impact models, we use total annual household income as the dependent variable (measured in thousand Thai Baht) and sweet pepper adoption as the treatment variable, while controlling for other factors that might influence the outcome. ${ }^{4}$

At first, we estimate a simple OLS regression, employing a dummy for sweet pepper adoption. However, since adoption in our sample is not random, we might face a selection problem, leading to a biased estimate of the effect of sweet pepper adoption on household income. Following Miyata et al. (2009) and Bolwig et al. (2009) we account for this by using a treatment effect model, also called the Heckman selection correction model (Greene, 2003), which involves two equations. First, the adoption equation, which estimates the probability of sweet pepper adoption, and second, an outcome equation, which estimates household income as a function of various farm and household characteristics. The latter also includes a dummy variable for sweet pepper adoption and a correction term calculated from the first equation that adjusts the outcome equation for a possible selection bias. ${ }^{5}$

For model estimation, we implement a full information maximum likelihood (FIML) procedure. The adoption equation is derived from the probit models discussed above (Table 2). Many of them do also appear in the outcome equation, while others do not, which is important for proper model identification. Separate tests revealed that ownership of a pick-up truck and the road condition dummies, which are significant in the adoption equation, do not have a direct effect on household income, so that we use these variables as instruments.

\subsubsection{Estimation results}

The results of the OLS and the treatment effect model are shown in Table 4. For the treatment effect model, the parameter ath $(\rho)$ at the bottom of the table is the inverse

\footnotetext{
${ }^{4}$ Households that had adopted sweet pepper only in 2007 are dropped from this analysis, because for them the 12-months income data partly refers to the situation before adoption.

${ }^{5}$ As an alternative to this treatment effect model, one could use propensity score matching (PSM) to control for selection issues. Yet, in our context we prefer the treatment effect model, because there may also be unobservable factors that influence sweet pepper adoption, whereas the PSM approach assumes that farmer heterogeneity is only due to observable factors.
} 
hyperbolic tangent of $\rho$. The latter captures the correlation between the error terms in the adoption and outcome equation. If $\operatorname{ath}(\rho)$ is significant, a selection bias exists, whereas an insignificant parameter points at no selection bias. Here, $\operatorname{ath}(\rho)$ is not significant, indicating that the OLS model leads to unbiased estimates. Therefore, this is our preferred model.

Sweet pepper adoption has a positive impact on household income. All other things equal, cultivating sweet pepper increases annual income by 112,000 Baht (US $\$ 3,397$ ). Mean annual income in the sample is 261,980 Baht, so that adoption of sweet pepper cultivation leads to an increase by $43 \%$. This is a substantial effect, demonstrating that product innovations can indeed improve the situation of smallholder farmers. Our findings are in line with results from earlier studies on adoption of high-value crops. Von Braun et al. (1989) showed that non-traditional export crops are substantially more profitable than traditional crops in Guatemala, a result that was later confirmed by Carletto et al. (2007) in the same setting. In a similar fashion, McCulloch (2002) and Maertens and Swinnen (2009) found a positive impact of export horticulture production on household income in Kenya and Senegal, respectively.

Besides production of high-value crops, much attention has recently been paid to the differentiation of marketing channels. Yet, research that empirically examines the effects of different marketing channels on total household income remains rare. Most studies are confined to the partial incomes of particular agricultural enterprises. Many of them show that integration in modern supply chains results in higher net earnings for the respective crop (Berdegué et al., 2006; Neven and Reardon, 2006; Asfaw et al., 2009; Natawidjaja et al., 2007; Roy and Thorat, 2008). However, Hernández et al. (2007) find that profits are roughly the same for farmers participating in supermarket and traditional market channels. We use two additional variables - namely Royal Project and company supply chain dummies - to analyze whether the choice of marketing channel has an important impact on the income of sweet pepper farmers in Thailand. 
Table 4: Impact of sweet pepper adoption on household income

\begin{tabular}{|c|c|c|c|c|}
\hline \multirow[b]{2}{*}{ Variable } & \multicolumn{2}{|c|}{ OLS } & \multicolumn{2}{|c|}{ Treatment effect model } \\
\hline & Coefficient & $\begin{array}{l}\text { Standard } \\
\text { error }\end{array}$ & Coefficient & $\begin{array}{l}\text { Standard } \\
\text { error }\end{array}$ \\
\hline $\begin{array}{l}\text { Sweet pepper adoption } \\
\text { (dummy) }\end{array}$ & $1.12^{*}$ & 0.61 & $1.73 * *$ & 0.87 \\
\hline Royal Project (dummy) & $2.13 *$ & 1.13 & $2.13 *$ & 1.10 \\
\hline $\begin{array}{l}\text { Company supply chain } \\
\text { (dummy) }\end{array}$ & -0.07 & 0.56 & -0.08 & 0.54 \\
\hline Female (dummy) & -0.16 & 0.38 & -0.21 & 0.39 \\
\hline Age (years) & $-0.04 *$ & 0.02 & -0.03 & 0.02 \\
\hline Education (years) & -0.02 & 0.09 & -0.03 & 0.09 \\
\hline $\begin{array}{l}\text { Value of non-land agricult. } \\
\text { assets ( } 100 \text { thsd. Baht) }\end{array}$ & 0.31 & 0.27 & 0.30 & 0.27 \\
\hline $\begin{array}{l}\text { Value of other assets } \\
\text { (100 thsd. Baht) }\end{array}$ & $0.65 * *$ & 0.30 & $0.64 * *$ & 0.30 \\
\hline Land owned (rai) & 0.03 & 0.04 & 0.03 & 0.04 \\
\hline Land title (dummy) & 0.78 & 0.51 & 0.67 & 0.50 \\
\hline Family labor endowment & 0.04 & 0.17 & 0.04 & 0.16 \\
\hline $\begin{array}{l}\text { Info source trader/dealer } \\
\text { (dummy) }\end{array}$ & $0.63 *$ & 0.36 & $0.68 *$ & 0.36 \\
\hline Off-farm occupation (dummy) & $0.72 *$ & 0.38 & $0.81 * *$ & 0.40 \\
\hline Extension contact (dummy) & $-1.13 * * *$ & 0.42 & $-1.24 * * *$ & 0.44 \\
\hline Constant & 1.12 & 1.76 & 0.54 & 1.97 \\
\hline $\operatorname{ath}(\rho)$ & -- & -- & -0.15 & 0.14 \\
\hline F-statistics/Wald chi2 & $3.51 * * *$ & & $42.24 * * *$ & \\
\hline
\end{tabular}

Notes: The dependent variable is household income, which is measured in 100 thsd. Baht per year. Standard errors are robust. The number of observations is 288 .

$*, * *, * * *$ significant at the $10 \%, 5 \%$, and $1 \%$ level, respectively.

Source: Own calculations 
As Table 4 shows, supplying sweet pepper to the Royal Project has a significantly positive effect on household income. However, as mentioned above, this marketing channel is partly subsidized and only accessible for certain hill tribe minorities, so that it cannot be considered a model for large-scale expansion. Strikingly, however, company supply chains, which only include farmers supplying sweet pepper to private companies, do not show a significant impact. This should not be misinterpreted as evidence that modern supply chains cannot contribute to income growth and development in this particular context. On the contrary, sweet pepper in Thailand was initially introduced through modern supply chains, and, as shown, adoption of this product innovation contributes substantially to increases in household income. Yet, over time, these benefits of modern supply chains have spilled over also to traditional markets, such that today the type of marketing channel does not matter anymore. It is not surprising, hence, that most of the sweet pepper farmers now sell their produce to traditional village traders through spot-market transactions, which offer greater flexibility. Overall, these results suggest that only comparing the incomes of modern supply chain participants and non-participants at a certain point in time, as done in many previous studies, can lead to significant underestimation of the overall effect.

The other coefficient estimates in Table 4 highlight that off-farm occupation and the value of non-agricultural assets have the expected positive impact on household income. Additionally, having the trader/input dealer as the main source of information influences net income positively. This is interesting, because the same variable had a negative effect on sweet pepper adoption. Obviously, traditional traders and input dealers are not the best source of information when it comes to new supply chain opportunities, but having good relations with them is still advantageous from an income perspective. It would be interesting here to analyze the situation over time, as it might well be that the trader/dealer effect was different previously, when sweet pepper was not yet traded in traditional markets. Unfortunately, however, we do not have detailed income data for previous years, as this is very difficult to obtain in a recall survey. Somewhat surprisingly, having contacts with extension agents has a negative net impact on household income, albeit the variable positively influences sweet pepper adoption. This suggests that public extension agents are a good source of information for innovations in general, but they are rather ineffective in assisting 
farmers to implement profit-increasing cultivation or marketing practices. This is plausible for the example analyzed, as sweet pepper comes along with new cultivation technologies that were introduced by the private sector. These findings point at scope for improvement in the public extension service.

Table 5: Impact of timing of sweet pepper adoption on household income (OLS)

\begin{tabular}{|c|c|c|}
\hline Variable & Coefficient & Standard error \\
\hline Sweet pepper adoption, early (dummy) & $2.04 * *$ & 0.80 \\
\hline Sweet pepper adoption, middle (dummy) & $1.30 * *$ & 0.64 \\
\hline Sweet pepper adoption, late (dummy) & 0.46 & 0.66 \\
\hline Royal Project (dummy) & $2.23 * *$ & 1.10 \\
\hline Company supply chain (dummy) & 0.01 & 0.54 \\
\hline Female (dummy) & -0.09 & 0.39 \\
\hline Age (years) & -0.03 & 0.02 \\
\hline Education (years) & -0.03 & 0.09 \\
\hline $\begin{array}{l}\text { Value of non-land agricult. assets } \\
\text { (100 thsd. Baht) }\end{array}$ & 0.23 & 0.28 \\
\hline $\begin{array}{l}\text { Value of other assets } \\
\text { (100 thsd. Baht) }\end{array}$ & $0.55 * *$ & 0.28 \\
\hline Land owned (rai) & 0.03 & 0.04 \\
\hline Land title (dummy) & 0.67 & 0.51 \\
\hline Family labor endowment & 0.02 & 0.16 \\
\hline Info source trader/dealer (dummy) & 0.57 & 0.36 \\
\hline Off-farm occupation (dummy) & $0.88 * *$ & 0.37 \\
\hline Extension contact (dummy) & $-1.40 * * *$ & 0.43 \\
\hline Constant & 1.29 & 1.77 \\
\hline F-statistic & $4.13 * * *$ & \\
\hline
\end{tabular}

Notes: The dependent variable is household income, which is measured in 100 thsd. Baht per year. Standard errors are robust. The number of observations is 288 .

$*, * *, * * *$ significant at the $10 \%, 5 \%$, and $1 \%$ level, respectively.

Source: Own calculations 
Table 5 shows results of an additional model, where we disaggregate the adoption variable into separate dummies for early (1999-2003), middle (2004-2005) and late adopters (2006-2007). As one would expect, the timing of the adoption decision matters, with earlier adopters gaining significantly more than later adopters. This is in line with findings by Carletto et al. (2007) from their study in Guatemala. In our case, early adoption increases household income by 204,000 Baht $(6,172$ US\$) or $78 \%$ compared to the sample mean. Adoption in the middle period increases income by $50 \%$, whereas the effect for late adopters is not significant anymore. Results for the other variables are comparable to those in Table 4. As pointed out above, we only have income data for one year, so that we do not know how the adoption benefits as such developed over time. The fact that the early adopters still benefit more today than their later-adopting colleagues is probably due to the longer experience that they have with the innovation, potentially resulting in higher production and marketing efficiency. It would be interesting to analyze such aspects more explicitly in followup research.

\subsection{Conclusions}

We have analyzed the adoption and impacts of sweet pepper cultivation among smallholder farmers in Thailand. The crop was introduced in the country some 10 years ago as a product innovation, mainly meant for exports and upscale domestic supermarkets. During the initial years, specialized companies were the only available marketing channel; these companies primarily contracted northern upland farmers in easily accessible locations, in order to limit transaction costs associated with private extension and monitoring. Accordingly, bad infrastructure and transport conditions, as well as limited access to good information, constituted serious adoption constraints in the beginning and slowed down the adoption process. Over time, sweet pepper gained wider popularity among Thai consumers, so that it is now traded also in more traditional wholesale and retail markets. Information about sweet pepper production became more widely available, and village traders entered the market, so that some of the initial adoption constraints for farmers were eased.

Our impact analysis has shown that sweet pepper cultivation contributes significantly to higher household incomes. This underlines that adopting product innovations can 
be an important avenue for smallholder farmers to improve their situation. Strikingly, at this stage of the innovation diffusion process, supplying sweet pepper to modern supply chains does not lead to higher incomes than supplying to traditional markets. This suggests that, at the current stage of market development, the product innovation as such matters more than the type of supply chain. Although product innovations in developing countries are often introduced initially through modern supply chains, positive spillovers to traditional markets occur. Our findings indicate that such spillovers should not be underestimated; they need to be accounted for in future studies of the wider implications of modern supply chains.

However, further market differentiation can be expected in the future, and the positive income effects for farmers participating in the Royal Project suggest that additional benefits can be realized when selling in the top tier of modern supply chains. Hence, the question as to how smallholder farmers can access these market segments on a wider scale must not be overlooked from a development perspective. Furthermore, even though spillovers from modern supply chains might lead to better innovation access and positive income effects also in traditional markets, disadvantaged farmers will only benefit with a time lag. And, our results show that even after adoption the benefits are much smaller for late adopters than they are for early adopters. Therefore, to avoid negative income distribution effects, it is a policy challenge to overcome the initial adoption constraints for disadvantaged farmers, and help them to better link to modern supply chains. In the particular case analyzed here, concrete recommendations include addressing infrastructure weaknesses and transportation problems, granting land titles to farmers, and improving their access to proper information.

In general, the agricultural and food system transformation in developing countries will lead to faster changing market conditions in the future. Policy support is needed to make smallholder farmers better prepared for the dynamic adaptations needed, in order to maintain and increase their competitiveness. 


\section{Supply chain differentiation, contract agriculture, and farmers' marketing preferences: the case of sweet pepper in Thailand}

\subsection{Introduction}

The transformation of agri-food systems towards high-value supply chains implies a modernization of procurement systems in developing countries (Boselie et al., 2003; Reardon et al., 2003). Supermarkets in particular increasingly switch from buying through spot-market transactions to contractual agreements with farmers, often through specialized intermediaries (Balsevich et al., 2006; Berdegué et al., 2005; Neven et al., 2009). There is an emerging body of literature analyzing how smallholders can be linked successfully to modern supply chains (e.g., Asfaw et al., 2009; Henson et al., 2005; Maertens and Swinnen, 2009). There are also numerous studies discussing the benefits and risks of contract agriculture (Glover, 1987; Gow and Swinnen, 2001; Mangala and Chengappa, 2008; Peterson et al., 2001; Simmons et al., 2005; Singh, S., 2002). However, both strands of literature hardly address details 
of concrete contractual arrangements between sellers and buyers in the context of emerging value chains and modernizing retail structures. This is considered a drawback, because the design of contracts can crucially affect smallholder participation.

A second facet that both strands of literature hardly consider is the farmers' point of view. With few exceptions (Blandon et al., 2009; Guo et al., 2007; Masakure and Henson, 2005), available studies explain farmers' participation in modern supply chains through farm, household, and contextual characteristics, without explicitly accounting for subjective preferences. This implicitly assumes that all farmers would sell in modern supply chains, if they were able to. In reality, this may not always be the case.

The present study addresses these research gaps by analyzing marketing channels of sweet pepper producers in Thailand. Sweet pepper was introduced in Thailand some 10 years ago, mainly for exports and upscale domestic supermarkets. Over time, it gained wider popularity among domestic consumers, so that sweet pepper is nowadays also traded in more traditional wholesale and retail markets. Moreover, different contractual arrangements between farmers and traders can be observed.

Building on primary survey data, we analyze three main aspects. First, we describe institutional details of coexisting marketing channels and highlight differences between traditional and modern supply chains. Second, we examine farmers' subjective motivations to participate in particular marketing channels. And third, a choice experiment is used to analyze farmers' attitudes towards contracts in general and different contract designs.

The rest of the article proceeds as follows. The next section gives some background information about the empirical database, the particular study region, and the existing marketing channels for sweet pepper in Thailand. Subsequently, different institutional arrangements between farmers and traders are compared, and reasons for farmers' marketing decisions are analyzed, before the choice experimental results are discussed. The last section concludes. 


\subsection{Database and background}

\subsubsection{Database}

For our empirical study, we conducted a survey of 246 sweet pepper farmers in the Mae Sa watershed in Chiang Mai Province, northern Thailand. This watershed is where domestic sweet pepper cultivation had started in 1999, and it is still the main production area for sweet pepper in Thailand. The survey was conducted between May and July 2007. The Mae Sa watershed consists of 22 villages in total, but sweet pepper is cultivated in only 9 villages. Within these 9 villages, all sweet pepper growers were interviewed, using a structured questionnaire especially designed for this research.

\subsubsection{Marketing channels for sweet pepper}

Sweet pepper was introduced in Thailand in 1999 by a Dutch company. Because of climatic conditions, the northern upland areas were the primary target regions, especially those near the city of Chiang Mai, where infrastructure and market access conditions were relatively favorable. In particular, the company chose the Mae Sa watershed, where farmers were contracted to produce red and green sweet pepper in greenhouses, using hydroponics systems that make cultivation independent from soil quality conditions. Sweet pepper cultivation is labor and input intensive and associated with high capital investments, since sophisticated greenhouses are required. Since farms in the watershed are predominantly small-scale, with an average farm size of 0.7 hectares, the company initially provided credit, private extension, and certain inputs to contracted farmers.

In 2007, three different marketing channels existed for farmers. The first consists of private agribusiness firms that deal with sweet pepper for export and for domestic supermarkets. Beyond the Dutch company that had started the business in 1999, two additional firms have entered the market more recently. All three companies purchase sweet pepper from local farmers. The second marketing channel is the socalled Royal Project, which started to deal with sweet pepper in 2002. The Royal Project is a subsidized initiative by the King of Thailand to support disadvantaged farmers in the upland areas and offer alternatives to opium production, which was widespread in the 1970s and 80s. The Project sells vegetables and other agricultural 
products in upscale retail outlets under its own brand name, which Thai consumers recognize as being of very high quality. However, only hill tribe farmers, who make up a relatively small part of the population in the Mae Sa watershed, officially have access to the Royal Project marketing channel. We consider these first two marketing options as modern retail channels. In contrast, the third channel involves traditional village traders, who also entered the sweet pepper market more recently. They mostly supply traditional wholesale and retail markets in Chiang Mai and Bangkok.

Figure 2: Sweet pepper adoption and supply of different marketing channels, $1999-2007$

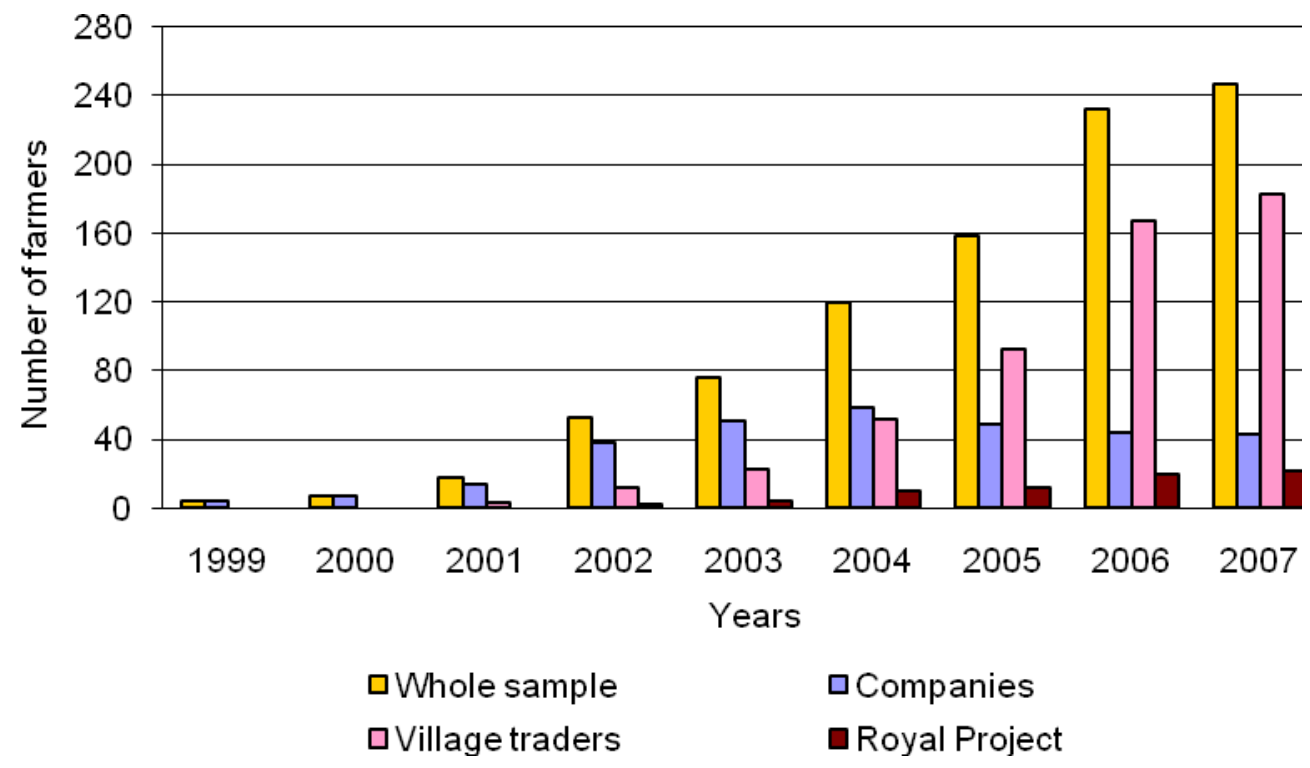

Source: Own calculations

Figure 2 shows the development of these three marketing channels over time. In the first two years, all farmers sold their sweet pepper through the company channel. However, since 2005 traditional village traders have constituted the most important marketing channel, while the number of farmers supplying a company is steadily decreasing. The role of the Royal Project increased over time, but the overall market share remains relatively small. Managers of the three companies stated in interviews with us that they did not reduce the cooperation with local farmers from their side. Hence, the declining number of company channel suppliers appears to be driven 
mainly by farmer preferences to sell to village traders. Hence, understanding such preferences is important to explain farmer participation in modern retail channels.

\subsection{Supply chain differentiation and contractual arrangements}

\subsubsection{Contractual arrangements in different marketing channels}

In a first step, we are interested in the importance of contractual arrangements in the different marketing channels. Figure 3 shows that more than half of all sweet pepper farmers sell without any contractual arrangement. However, not all of these sales without contract are spot-market transactions in a narrow sense, because farmers often have long-term informal relationships with their buyers without considering this as a binding arrangement. In those cases, concrete transactions are not agreed upon in advance, so that farmers remain flexible in their marketing decisions. Figure 3 also confirms that contractual arrangements are more frequently used in modern than in traditional supply chains.

Figure 3: Importance of contracts by marketing channel, 2007

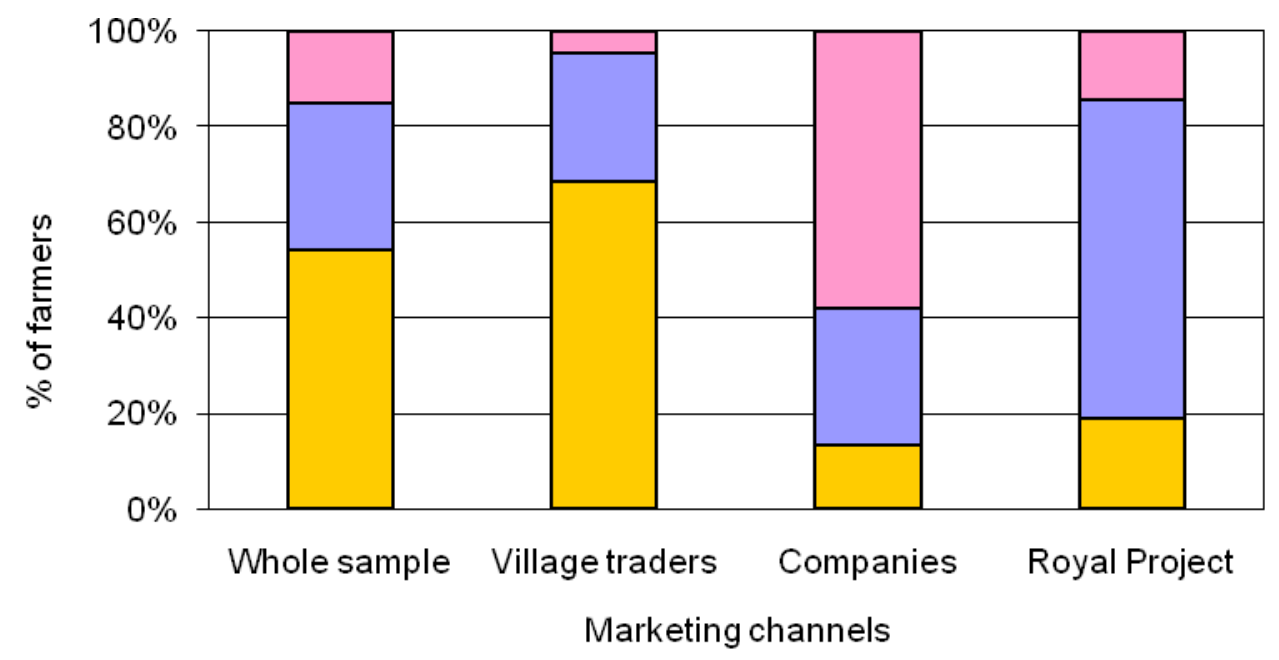

口Farmers without a contract

口Farmers having an oral contract

口Farmers having a written contract

Source: Own calculations

We further differentiate between oral and written contracts. Oral contracts are observed more often, although the picture differs across marketing channels. Private companies in particular use more written contracts. As they are run by non-locals, 
company agents are not integrated into the farmers' social networks; hence, they would not trust oral arrangements. This has also been reported in other contexts (Guo et al., 2007; Nagaraj et al., 2008).

\subsubsection{Comparison of contract details}

In the literature, it is often separated between production contracts and marketing contracts (Guo and Jolly, 2008; Singh, S., 2002; Wiboonpongse et al., 1998). Even though in our case all contractual arrangements comprise some features of both, marketing components dominate in contracts with traditional village traders and companies, whereas Royal Project contracts focus more directly also on production aspects.

\section{Figure 4: Aspects that are regulated in contracts by marketing channel}

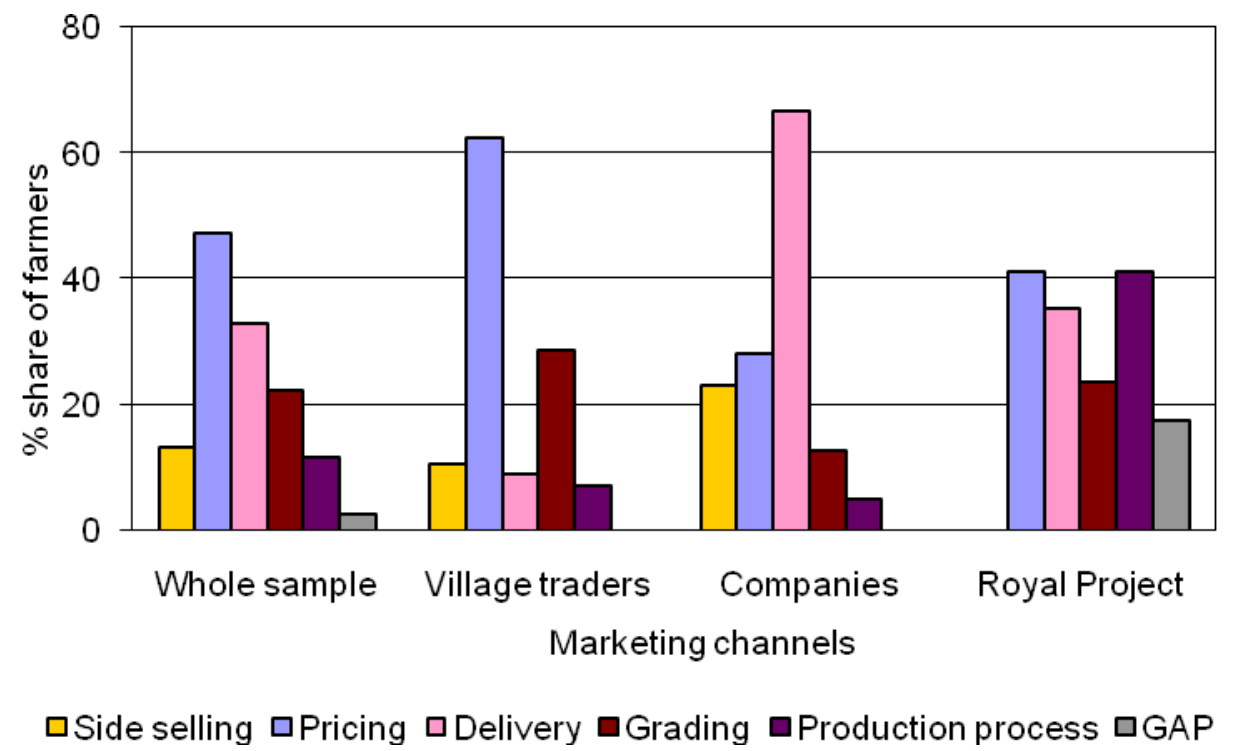

Source: Own calculations

Figure 4 displays aspects that are regulated in contracts, differentiated by marketing channel. Most contracts refer to more than one aspect, so that the figure columns sum up to more than $100 \%$. In contracts with village traders, pricing is by far the most important component; usually a minimum procurement price is specified. Another important component in village trader contracts is the specification of grading criteria. Given that high-value market segments for vegetables in Thailand are still emerging, uniform quality standards do not yet exist. In contrast, in company con- 
tracts the timing of delivery is the central feature, followed by pricing and agreements about side selling (i.e., whether or not sales to other buyers are allowed). Grading criteria play a smaller role; at least the biggest of the three companies uses a grading machine, so that special contractual specifications are not required. In the Royal Project channel, most contracts refer to pricing and details about the production process. The Royal Project is also the only marketing channel that requires a Good Agricultural Practice (GAP) certificate from some suppliers. ${ }^{6}$

Another interesting aspect in some contracts relates to input delivery. Yet, as village traders sometimes also sell inputs to farmers that are not contracted, related details are not included in Figure 4, but shown separately in Table 6.

Table 6: Input delivery and payment mode for output sales (in \%)

\begin{tabular}{|c|c|c|c|c|c|}
\hline \multirow[b]{2}{*}{ Inputs } & \multicolumn{2}{|c|}{$\begin{array}{c}\text { Comparison between } \\
\text { contracts }\end{array}$} & \multicolumn{3}{|c|}{$\begin{array}{c}\text { Comparison between } \\
\text { contract farmers }\end{array}$} \\
\hline & No contract & Contract $^{\mathrm{a}}$ & $\begin{array}{l}\text { Village } \\
\text { traders }\end{array}$ & Companies $^{c}$ & $\begin{array}{c}\text { Royal } \\
\text { Project }^{d}\end{array}$ \\
\hline Input delivery & 40.16 & $74.11 * * *$ & $58.93 * *$ & $84.62 * * *$ & $100 * * *$ \\
\hline \multicolumn{6}{|c|}{ Payment for output sales } \\
\hline At delivery & 22.95 & $13.39^{*}$ & 17.86 & 10.26 & 5.88 \\
\hline $\begin{array}{l}\text { Within one } \\
\text { week }\end{array}$ & 25.41 & 30.36 & 26.79 & 41.03 & 17.65 \\
\hline $\begin{array}{l}\text { Later than one } \\
\text { week }\end{array}$ & 51.64 & 56.25 & 55.36 & 48.72 & 76.47 \\
\hline \multicolumn{6}{|c|}{$\begin{array}{l}\text { Notes: } *, * *, * * \text { differences are significant at the } 10 \%, 5 \% \text {, and } 1 \% \text { level, respectively. Significant } \\
\text { levels were obtained from a chi2-test. } \\
\text { a Significance levels in this column refer to the difference between contract and non-contract farmers. } \\
{ }^{b} \text { Significance levels in this column refer to the difference between village trader suppliers with and } \\
\text { without contract. }{ }^{c} \text { Significance levels in this column refer to the difference between contract company } \\
\text { and contract village trader suppliers. }{ }^{\mathrm{d}} \text { Significance levels in this column refer to the difference be- } \\
\text { tween contract Royal Project and contract village trader suppliers. } \\
\text { Source: Own calculations }\end{array}$} \\
\hline
\end{tabular}

The first two Table columns compare the situation of farmers with and without contract, whereas the other columns further differentiate between marketing channels.

\footnotetext{
${ }^{6}$ Farmers can get a GAP certificate when they produce according to standard set up by the Thai Ministry of Agriculture and Cooperatives for each product. Products produced under the GAP certificate can be sold in retail markets under the so-called Q-label (Q standing for quality).
} 
To facilitate comparisons and better highlight differences in contractual details between channels, the group of "no contract" farmers only refers to those that sell to traditional village traders without a contract, whereas in the modern retail channels, we only consider the majority of farmers that sell under contract.

The results show that the percentage of farmers who purchase inputs from the same trader that they also sell to is significantly higher among contract farmers. Under contract, inputs can be bought on credit, whereas non-contract farmers usually have to pay directly in cash. Hence, better access to inputs may be one reason for farmers to enter into contractual arrangements, which will be analyzed more explicitly further below. Overall, input delivery plays a bigger role in modern retail channels than in traditional supply chains.

Looking at the timing of contractual arrangements (Table 7), we find that most contracts are made before the production process starts. This holds true in all marketing channels, although the share of contracts that are only made before the harvest is bigger in traditional than in modern supply chains. This suggests that contracts with village traders provide somewhat greater flexibility for farmers. Yet, in terms of contract duration, Table 7 shows that almost all contracts are relatively short term in nature, mostly referring to only one production season. A similar result was reported by Guo and Jolly (2008).

Table 7: Timing and duration of contracts (in \%)

\begin{tabular}{lcccc}
\hline Timing & $\begin{array}{c}\text { All contract } \\
\text { farmers }\end{array}$ & $\begin{array}{c}\text { Village } \\
\text { traders }\end{array}$ & Companies $^{\mathbf{a}}$ & $\begin{array}{c}\text { Royal } \\
\text { Project }^{\mathbf{b}}\end{array}$ \\
\hline Before production & 71.43 & 53.57 & $87.18^{* * *}$ & $94.12^{* * *}$ \\
Before harvest & 28.57 & 46.43 & $12.82^{* * *}$ & $5.88^{* * *}$ \\
Duration & & & & \\
One season & 91.96 & 89.29 & $100.00^{* *}$ & 82.35 \\
Ongoing & 8.04 & 10.71 & $0.00^{* *}$ & 17.65 \\
\hline
\end{tabular}

Notes: $* *, * * *$ differences are significant at the $5 \%$, and $1 \%$ level, respectively. Significant levels were obtained from a chi2-test.

${ }^{\text {a }}$ Significance levels in this column refer to the difference between contract company and contract village trader suppliers. ${ }^{\mathrm{b}}$ Significance levels in this column refer to the difference between contract Royal Project and contract village trader suppliers.

Source: Own calculations 


\subsection{Reasons for farmers' marketing decisions}

After having described the existing marketing channels for sweet pepper and related institutional details, we now want to analyze farmers' motivations behind participating in particular channels. In the following, we first compare economic incentives before examining subjective reasons as stated by respondents in the interviews.

\subsubsection{Economic incentives}

The first and most obvious potential economic incentive for participating in a particular marketing channel is the expected or actual output price received. Table 8 shows how prices compare across marketing channels. Sweet pepper prices differ according to color and grade. There is green and red sweet pepper, and both colors are traded in the grades $\mathrm{AB}$ and $\mathrm{C}$.

Table 8: Average sweet pepper prices in Thai Baht per kg

\begin{tabular}{|c|c|c|c|c|}
\hline \multirow[b]{2}{*}{$\begin{array}{c}\text { Variety and } \\
\text { grade }\end{array}$} & \multirow{2}{*}{$\begin{array}{c}\begin{array}{c}\text { Non-contract } \\
\text { farmers }\end{array} \\
\text { Village traders }\end{array}$} & \multicolumn{3}{|c|}{ Contract farmers } \\
\hline & & Village traders ${ }^{\mathrm{a}}$ & Companies $^{\mathrm{b}}$ & Royal Project $^{c}$ \\
\hline Green, $\mathrm{AB}$ & 32.78 & 30.72 & 32.99 & $40.58 * * *$ \\
\hline Green, C & 21.14 & 19.40 & 20.09 & 20.93 \\
\hline Red, $\mathrm{AB}$ & 43.37 & $49.35^{*}$ & 44.79 & $61.64 *$ \\
\hline Red, C & 28.66 & 30.67 & 28.07 & 34.03 \\
\hline
\end{tabular}

Notes: $* * * *$ differences are significant at the $10 \%$ and $1 \%$ level, respectively. Significant levels were obtained from a t-test.

${ }^{a}$ Significance levels in this column refer to the difference between village trader suppliers with and without contract. ${ }^{b}$ Significance levels in this column refer to the difference between contract company and contract village trader suppliers. ${ }^{\mathrm{c}}$ Significance levels in this column refer to the difference between contract Royal Project and contract village trader suppliers.

Source: Own calculations

Surprisingly, differences between contract and non-contract transactions are relatively small in many cases. Comparing the three contract marketing channels, the Royal Project always pays the best price, especially for the higher grade. Yet, these prices are partly subsidized, and, as mentioned above, participation in this channel is confined to certain minority groups. Companies pay a slightly higher price than village traders for green and a lower price for red sweet pepper, yet these differences are not statistically significant. This suggests that price differences may not be the 
main factor explaining farmers' marketing choices. Similar results were also found in other contexts (Hernández et al., 2007; Nagaraj et al., 2007), although there are also examples with more considerable price differences between traditional and modern supply chains (Balsevich et al., 2006; Mangala and Chengappa, 2008).

In order to analyze economic incentives more broadly, we compare costs, revenues, and gross margins of sweet pepper production across marketing channels in Table 9. Contract farmers tend to have higher yields than non-contract farmers, regardless of whether they participate in traditional or modern retail channels. This also leads to higher revenues and gross margins. While these comparisons cannot establish causality, they still provide a hint that expected financial benefits may play a role for farmers to engage in contractual arrangements.

Table 9: Gross margin analysis in Thai Baht per acre

\begin{tabular}{|c|c|c|c|c|}
\hline \multirow[b]{2}{*}{ Particulars } & \multirow{2}{*}{$\begin{array}{c}\begin{array}{c}\text { Non-contract } \\
\text { farmers }\end{array} \\
\text { Village traders }\end{array}$} & \multicolumn{3}{|c|}{ Contract farmers } \\
\hline & & $\begin{array}{l}\text { Village } \\
\text { traders }\end{array}$ & Companies $^{\text {b }}$ & $\begin{array}{c}\text { Royal } \\
\text { Project }^{\mathrm{C}}\end{array}$ \\
\hline Yields (kg/acre) & 6,292 & $8,028 * *$ & 8,192 & $11,335^{* *}$ \\
\hline $\begin{array}{l}\% \text { share of red sweet } \\
\text { pepper in total har- } \\
\text { vest }\end{array}$ & 52.13 & 43.22 & $79.70 * * *$ & $70.31 * *$ \\
\hline Revenues & 210,593 & $284,648 * * *$ & 323,255 & $576,292 * * *$ \\
\hline $\begin{array}{l}\text { Input costs } \\
\text { (chemicals and } \\
\text { fertilizer) }\end{array}$ & 55,440 & $70,280^{*}$ & 77,582 & 85,917 \\
\hline Seed costs & 18,731 & 21,875 & $31,355^{*}$ & 28,804 \\
\hline Labor costs & 9,842 & 7,061 & 13,322 & 15,864 \\
\hline Total variable costs & 84,013 & 99,216 & 122,259 & 130,585 \\
\hline Gross margin & 126,580 & $185,431 * *$ & 200,996 & $445,707 * * *$ \\
\hline \multicolumn{5}{|c|}{$\begin{array}{l}\text { Notes: } *, * *, * * * \text { differences are significant at the } 10 \%, 5 \% \text {, and } 1 \% \text { level, respectively. Significant } \\
\text { levels were obtained from a t-test. } \\
\text { a Significance levels in this column refer to the difference between village trader suppliers with and } \\
\text { without contract. }{ }^{b} \text { Significance levels in this column refer to the difference between contract company } \\
\text { and contract village trader suppliers. }{ }^{c} \text { Significance levels in this column refer to the difference be- } \\
\text { tween contract Royal Project and contract village trader suppliers. } \\
\text { Source: Own calculations }\end{array}$} \\
\hline
\end{tabular}


Comparing the three contract channels, it becomes obvious that participation in the Royal Project is particularly lucrative for those farmers who are eligible to this channel. Though not statistically significant, mean gross margins are also slightly higher in company channels than in village trader contract channels. This can mostly be explained by the greater importance of red-colored sweet pepper varieties that fetch higher prices than green ones. Hence, modern retail channels seem to offer a certain advantage over traditional markets. The fact that many farmers nevertheless drop out of the company channel may potentially be due to their inability to produce more red sweet pepper. Another possible reason may be that financial incentives are too small to compensate for perceived disadvantages associated with supplying companies, such as less flexible contracts. This will be further analyzed below.

\subsubsection{Subjective reasons stated by farmers}

Both the number and the share of farmers that supply sweet pepper through company channels have declined over time. Of the $46 \%$ farmers in the sample who once supplied to companies in the past, only $18 \%$ continued to do so in 2007 . Further disaggregation reveals that $47 \%$ of all farmers always only supplied village traders, $18 \%$ always only supplied a company, and 9\% always only supplied the Royal Project. The remaining $26 \%$ changed from supplying a company to supplying a village trader. Table 10 summarizes the farmers' answers to a question about the most important perceived advantages of their own marketing channel in comparison with other alternatives. Only answers from those farmers who always supplied to the same marketing channel are considered here.

There is a striking difference in stated advantages between non-contract and contract village trader suppliers. Whereas price is by far the most important perceived advantage for contract suppliers, non-contract farmers value their independence highest, closely followed by price, and the ability to discuss with the trader. Hence, losing degrees of freedom and the option to negotiate on the spot seem to be important reasons for some farmers not to engage in contracts. The statements about price advantages may appear somewhat contradictory; they reflect that sweet pepper markets are not always fully transparent. As discussed, actual differences in mean prices with and without contract are relatively small. 
Table 10: Farmers' perceived advantages of supplying to a particular marketing channel (in \%)

\begin{tabular}{|c|c|c|c|c|c|c|}
\hline \multirow{2}{*}{$\begin{array}{l}\text { Non-contract } \\
\text { farmers } \\
\text { Village traders }\end{array}$} & & \multicolumn{5}{|c|}{ Contract farmers } \\
\hline & & Village traders & Companies & & Royal Project & \\
\hline Independence & 31 & Price & 43 Market access & 50 & Input provision & 67 \\
\hline Price & 29 & Input provision & 14 Input provision & 50 & Market access & 52 \\
\hline $\begin{array}{l}\text { Ability to } \\
\text { discuss }\end{array}$ & 23 & $\begin{array}{l}\text { Personal } \\
\text { relation }\end{array}$ & $\begin{array}{l}\text { Knowledge } \\
14 \text { transfer }\end{array}$ & 23 & Price & 48 \\
\hline $\begin{array}{l}\text { Personal } \\
\text { relation }\end{array}$ & 17 & Independence & 11 Price & 18 & $\begin{array}{l}\text { Knowledge } \\
\text { transfer }\end{array}$ & 43 \\
\hline Transport & 4 & Transport & 11 & & & \\
\hline & & Ability to discuss & 8 & & & \\
\hline
\end{tabular}

Note: Only farmers who always supplied to the same marketing channel are considered.

Source: Own calculations

For modern retail channel suppliers, assured market access and input provision are the most important perceived advantages, suggesting that imperfections in input and output markets are generally felt as a constraint. This may be due to seasonal market saturation in traditional channels, and credit constraints, among other reasons. Similarly, Masakure and Henson (2005) found market uncertainty as a major reason for vegetable farmers in Zimbabwe to contract with an export company, while Minten et al. (2009) identified the option to obtain inputs on credit as an important factor among vegetable producers in Madagascar; in both these studies, higher incomes were only mentioned as a minor incentive to sign a contract.

Table 11 looks at statements by farmers who decided to change their marketing channel from supplying companies to supplying village traders either with or without contract. Knowledge transfer followed by input provision are the most important reasons why those farmers initially supplied a company. This makes sense, because companies had introduced sweet pepper in Thailand and were the only buyers of output and sellers of specific inputs during the first years. Now that related production technologies are more established, company contracts are no longer a precondition for growing sweet pepper. Accordingly, many farmers have switched permanently to supplying village traders. Indeed, most of the farmers who changed their marketing 
channel over time had started sweet pepper production in the early phase between 1999 and 2001.

Table 11: Farmers' stated reasons for changing marketing channels (in \%)

\begin{tabular}{lllllll}
\hline $\begin{array}{c}\text { Initial reasons } \\
\text { for company } \\
\text { supply }\end{array}$ & $\begin{array}{c}\text { Reasons for } \\
\text { change }\end{array}$ & $\begin{array}{c}\text { Advantages from } \\
\text { supplying village } \\
\text { traders } \\
\text { (with contract) }\end{array}$ & $\begin{array}{c}\text { Advantages from } \\
\text { supplying village } \\
\text { traders } \\
\text { (without con- } \\
\text { tract) }\end{array}$ \\
\hline $\begin{array}{l}\text { Knowledge } \\
\text { transfer }\end{array}$ & $50 \begin{array}{l}\text { Intransparent } \\
\text { grading }\end{array}$ & 50 & Price & 58 Price & 44 \\
$\begin{array}{l}\text { Input provision } \\
\text { Market access }\end{array}$ & 21 Price & 33 & Ability to discuss & 16 Independence & 35 \\
& Transport & 8 & Independence & 11 relation & 20 \\
\hline
\end{tabular}

Note: Only farmers who changed their sweet pepper marketing channel over time are considered.

Source: Own calculations

When asked about concrete reasons for withdrawing from companies, many farmers named strict and intransparent grading procedures (Table 11). Companies tend to grade in the absence of farmers. Moreover, at least one company uses a grading machine, so that farmers have no scope for discussion. These results support our earlier finding that there is limited trust between farmers and companies. Whereas written contracts can help to overcome some problems of trust from the companies' point of view, they hardly address farmers' concerns, at least not with the design used in this specific context. The second important reason stated for withdrawing is price, followed by the preference for independence. In a review of different studies, Sartorius and Kirsten (2007) also found that distrust, combined with a perceived loss of autonomy, is a major reason for contract failures between smallholder farmers and agribusiness companies.

Better prices are stated as the main advantage from supplying village traders with or without contract by those who switched (third and fourth column of Table 11). As expected, non-contract village trader suppliers value independence higher than farmers who entered into a new contract. However, the fact that still $11 \%$ of the contract 
suppliers mention independence reflects that contracts with village traders are perceived less confining than those with companies.

\subsection{Farmers' marketing preferences: a choice experiment}

In order to analyze farmers' attitudes towards contracts and specific contract designs more specifically, a choice experiment was carried out as part of the farm survey. In the following, we first describe the experimental design, before we discuss the econometric approach and the estimation results.

\subsubsection{Experimental design}

The choice experiment method is theoretically based on Lancaster's model of consumer choice and econometrically on random utility models (Adamowicz et al., 1998). The underlying assumption is that demand is defined over the characteristics of goods, rather than over goods themselves. Therefore, choice experiments consist of different alternatives of a good, which contain various attributes with different attribute levels. That is, the respondent has to choose a certain combination of attribute levels, which characterize the good, rather than the good as such. It is assumed that the respondent chooses the combination, which gives the highest subjective level of utility. Choice experiments were initially applied in marketing and environmental economics, but recently they found broader application. In our case, we apply a choice experiment to identify farmers' preferences and attitudes towards different 'characteristics' of a contractual arrangement.

Different experimental methods exist, such as contingent ranking, rating, and choice. Here we use the contingent choice approach, which is based on Louviere and Woodworth (1983); compared to the alternatives it builds on a somewhat more realistic setting, because farmers usually only select one out of several possible marketing channels. In the questionnaire and experimental design, we identified four contract attributes that we felt might be of importance for farmers, namely price, payment mode, input provision, and relation to the trader. Price has four levels of valuation, payment mode has two, and the other two attributes have three levels each (see Table 12). 
Table 12: Marketing channel attributes and attribute levels used in the contingent choice experiment

\begin{tabular}{|c|c|c|c|c|}
\hline \multirow[b]{2}{*}{ Attribute } & \multicolumn{4}{|c|}{ Attribute levels } \\
\hline & 1 & 2 & 3 & 4 \\
\hline $\begin{array}{l}\text { Price in Thai } \\
\text { Baht } / \mathrm{kg}\end{array}$ & Market price & +5 & +15 & +25 \\
\hline $\begin{array}{l}\text { Input/credit } \\
\text { provision }\end{array}$ & None & Seeds and chemicals & $\begin{array}{l}\text { Seeds, chemicals, and } \\
\text { additional credit }\end{array}$ & \\
\hline $\begin{array}{l}\text { Payment } \\
\text { mode }\end{array}$ & $\begin{array}{l}\text { Payment at } \\
\text { delivery }\end{array}$ & $\begin{array}{l}25 \% \text { of expected minimum } \\
\text { payment is paid a month } \\
\text { before harvest starts }\end{array}$ & & \\
\hline $\begin{array}{l}\text { Relation to } \\
\text { the buyer }\end{array}$ & $\begin{array}{l}\text { Buyer is } \\
\text { personally } \\
\text { known }\end{array}$ & $\begin{array}{l}\text { Buyer is known through } \\
\text { other village traders }\end{array}$ & $\begin{array}{l}\text { Buyer is not } \\
\text { known at all }\end{array}$ & \\
\hline
\end{tabular}

Source: Own investigation

This set of attributes and levels implies a total of $72(4 \times 2 \times 32)$ theoretically possible alternatives. By using an orthogonal design procedure (Louviere et al., 2000), a fraction of the complete factorial design was obtained, giving 16 alternatives to be presented to respondents. However, when testing the choice experiment, farmers assessed four of the alternatives to be quite unrealistic. For instance, a combination of the attribute levels 'not knowing the trader' with 'payment of $25 \%$ for a minimum quantity before harvest' was felt improbable. Following other studies (Gonzales et al., 2009), we excluded four unrealistic alternatives; while this reduces statistical efficiency (Lanscar and Louviere, 2006) it increases the degree of market realism. The remaining 12 alternatives were assigned to six choice sets, each comprising three alternatives: the first two were taken from the 12 orthogonally designed alternatives, and the third always displayed a combination of the lowest levels of all four attributes. In other words, the third option portrayed all the characteristics of the marketing situation of village trader suppliers without a contract, whereas the other two alternatives described a marketing option under contract with different contract characteristics. The two contract alternatives were purposely assigned to a choice set to ensure that none of the options is predominant and that attribute levels differ as much as possible. To avoid respondents' fatigue, only four of the six choice sets were used in 
each questionnaire. Questionnaires with different sequences of choice sets were developed and randomly assigned to farmers.

\subsubsection{Model specification}

The choice data thus obtained were analyzed using a random parameters logit (RPL) model, also known as mixed logit (Hole, 2007). There are several advantages over standard logit models. RPL models assume preference heterogeneity among respondents, implying that they not only estimate the mean of a coefficient, but also the standard deviation of the coefficient's distribution around the mean. When this standard deviation is significant, preference heterogeneity for the respective variable exists. Moreover, unrestricted substitution patterns are allowed in RPL models, and correlation in unobserved factors is possible, which relaxes the assumption of independence of irrelevant alternatives (Campbell et al., 2006). In our model, we fix the price coefficient across the population, because we assume that all farmers have the same preference for higher prices. The other three attributes are random parameters, for which we assume a normal distribution in the sample (Layton and Brown, 2000). We employ an alternative specific constant (ASC) for the third alternative, which is the non-contract village trader marketing channel. This variable reflects the general attitude of farmers towards marketing channels that do not involve contractual arrangements. A positive mean coefficient would imply a general preference for noncontract alternatives. In a second model, we additionally use interaction terms between the ASC and two dummy variables. The first dummy takes a value of one if farmers were producing under contract at the time of the interviews in 2007, whereas the second dummy takes a value of one if farmers produced under contract previously but stopped to do so at some point. Thus, these additional interaction terms help to identify whether actual contract experience influences general preferences.

\subsubsection{Estimation results}

The estimation results of the RPL model are reported in Table 13. Coefficient means as well as standard deviations for the random parameters are shown. With the exception of payment mode, all coefficient means are statistically significant at the $1 \%$ level. Results for the standard deviations in the lower part of Table 13 show that 
preference heterogeneity exists for all attributes, except for payment mode. This confirms the structural advantage in employing the RPL specification.

According to expectations, the coefficient of price is positive, indicating that contracts with higher prices increase farmers' utility and the probability of choosing a contract marketing channel. Likewise input provision, especially when combined with additional credit provision, is an incentive for farmers to engage in contracts, confirming some of our earlier findings. Relationship with the buyer also seems to be an important aspect for farmers. Coefficients for both levels of this attribute have a negative sign, indicating that the less a farmer knows the contract agent, the less likely he/she is to choose the contract channel. The reference level in our specification is that a farmer knows the buyer personally.

The positive coefficient for the ASC shows that farmers generally prefer a marketing channel that does not involve a contract. Yet, preference heterogeneity exists for this variable, so that not all farmers necessarily share the same negative attitude towards contractual arrangements. The results of the second model, which includes the two ASC-contract experience interaction terms as described above, are also displayed in Table 13. The ASC coefficient itself is larger than in the first model, indicating that those without own contract experience have even more negative attitudes towards contracts in general. The coefficient of the first interaction term is negative and significant, indicating that the negative attitude is reduced among those that actually produced under contract in 2007. Given that farmers choose their marketing channel themselves, this is plausible. The coefficient of the second interaction term is not significant, implying that the hypothesis of equal general attitudes between those who stopped producing under contract and those who never had a contract cannot be rejected.

In summary, Thai sweet pepper farmers generally prefer a non-contract marketing channel. In terms of contract design, they favor arrangements involving higher specified prices and provision of inputs and credits. Moreover, they prefer contracts with traders or agents that they know personally. Our findings point in the same direction as those by Blandon et al. (2009), who analyzed marketing preferences of fruit and vegetable producers in Honduras, yet without explicitly looking at issues of contract design. Overall, these results confirm that - in addition to the usual constraints that 
smallholders face - their marketing preferences matter for the question whether or not they participate in modern supply chains.

Table 13: Random parameter logit model for farmers’ market channel choice

Model 1

Model 2

Attributes

Coefficients Std. error Coefficients Std. error

Mean parameter ${ }^{\mathrm{a}}$

Price

$0.06 * * *$

0.01

$0.06 * * *$

0.01

$\mathrm{ASC}^{\mathrm{b}}$

$1.38 * * *$

0.45

$3.11 * * *$

0.66

Input provision $^{\mathrm{c}}$

$1.04 * * *$

0.27

$1.10 * * *$

0.26

Input and credit provision ${ }^{\mathrm{c}}$

$1.30^{* * *}$

0.40

$1.41 * * *$

0.38

Payment in advance

0.19

0.24

0.19

0.23

Buyer known through others ${ }^{\mathrm{d}}$

$-2.34 * * *$

0.41

$-2.35 * * *$

0.41

Buyer not known ${ }^{\mathrm{d}}$

$-3.31 * * *$

0.40

$-3.36 * * *$

0.44

ASC $\mathrm{x}$ contract in 2007

ASC $\mathrm{x}$ previous contract

$-2.89 * * *$

0.67

$-1.26$

0.81

Standard deviation parameter

$\mathrm{ASC}^{\mathrm{b}}$

$3.93 * * *$

0.45

$3.61 * * *$

0.42

Input provision $^{\mathrm{c}}$

$0.63 *$

0.34

$-0.60^{*}$

0.36

Input and credit provision ${ }^{c}$

$-1.27 * *$

0.59

0.78

0.60

Payment in advance

$-0.18$

0.38

$-0.31$

0.28

Buyer known through others ${ }^{\mathrm{d}}$

$0.97 *$

0.58

$1.09 * *$

0.54

Buyer not known ${ }^{\mathrm{d}}$

$2.04 * * *$

0.43

$-2.11 * * *$

0.46

Log likelihood

$-653.76$

$-644.24$

Chi-squared

$309.91 * * *$

$280.01 * * *$

Notes: The number of observations is $\mathrm{n}=3 * 4 * 242=2,916$. Standard errors are shown in parentheses. $*, * *, * * *$ significant at the $10 \%, 5 \%$, and $1 \%$ level, respectively. ${ }^{a}$ All variables, except for price, are dummy variables. ${ }^{b}$ ASC stands for alternative specific constant. As explained in the text, this refers to the non-contract village trader alternative in our specification. ${ }^{\mathrm{c}}$ Reference category is no input provision. ${ }^{\mathrm{d}}$ Reference category is buyer is known personally.

Source: Own calculations 


\subsubsection{Willingness to accept analysis}

The estimated parameters from the RPL model can also be used to calculate the willingness to pay (WTP) for each single attribute, which further helps to understand respondents' incentive structures and quantify their preference levels. In consumer choice studies, WTP is used, as these studies usually explore how much a consumer is willing to pay for a certain attribute level that is included in a good they are asked to buy. In our case, however, farmers sell a good, so that the original question changes to what price a farmer is willing to accept (WTA), when a certain attribute level of a contract changes. WTA measures can be derived for each attribute level by dividing the coefficient of the attribute by the price coefficient and multiplying by -1 (Colombo et al., 2005).

We use the results from model 1 for these calculations. The highest WTA can be observed for the attribute levels referring to the relationship with the buyer. A farmer would require a sweet pepper price that is $55.20 \mathrm{Baht} / \mathrm{kg}$ higher to enter a contract with a buyer whom he/she does not know personally or through others. This is an increase of $127 \%$ compared to the average price for red sweet pepper paid by a village trader to non-contract farmers. The marginal WTA for entering a contract with a buyer that is not known personally but through others is $39.00 \mathrm{Baht} / \mathrm{kg}$, still implying an increase of $90 \%$. The WTA for the other significant variables is negative. Therefore, when chemicals and seeds are provided as part of the contract, farmers would accept a price that is $17.33 \mathrm{Baht} / \mathrm{kg}(40 \%)$ lower than if no inputs are provided (this is net of the actual input cost). When inputs and additional credit are provided, the marginal WTA is $-22.60 \mathrm{Baht} / \mathrm{kg}$, implying a price decrease of $52 \%$. Considering the ASC coefficient, we also find a negative WTA. A farmer would accept a price that is $23.00 \mathrm{Baht} / \mathrm{kg}(53 \%)$ lower when a marketing channel does not imply a contract of any form.

The exact WTA values should be interpreted with some caution, and their magnitude might have to be discounted somewhat, given the well-known hypothetical bias that stated preferences data often suffers from. However, there is no reason to believe that the hypothetical bias is stronger for some attributes than for others, so that a relative ranking can still be made. In this respect, it is particularly interesting to observe that for farmers the positive utility associated with knowing the buyer seems to outweigh 
the negative utility associated with entering a contract in general. This suggests that missing personal links between companies and farmers are more important than the fact that there are contracts as such for explaining farmers' withdrawal from the company marketing channel. This is probably related to issues of trust and is an important result for improving contractual relationships in high-value markets.

\subsection{Conclusions}

We have analyzed the marketing behavior of sweet pepper farmers in Thailand in the light of ongoing market differentiation. In particular, we examined the role and details of contractual arrangements to better understand farmers' market channel choices. Sweet pepper was introduced in Thailand some 10 years ago, mainly meant for exports and upscale domestic supermarkets. Initially, specialized companies were the only available marketing channel, purchasing sweet pepper from farmers via contractual arrangements. More recently, the Royal Project, which also caters for modern retail outlets, and traditional village traders entered the market. Whereas the Royal Project also mostly works with contracts, many village traders purchase sweet pepper from farmers without a contractual arrangement. Over time, village traders became the most important marketing channel for sweet pepper; many farmers who had previously sold to companies switched to supplying village traders.

Our descriptive comparison of marketing channels and contract features confirms that significant differences exist, which influence farmers' choices. While output prices matter, farmers also value other aspects such as access to inputs, credit, and information, as well as independence and flexibility. Contract marketing channels are associated with higher net incomes. Strikingly, however, gross margin differences between company and village trader contract suppliers are relatively small and not statistically significant.

A choice experiment was used to analyze farmers' attitudes towards contracts and related details more directly. The results reveal that farmers generally prefer noncontract marketing options. Yet there are certain factors that increase the attractiveness of entering into a contractual arrangement. For instance, contracts that also involve the provision of inputs and credit are clearly preferred. Remarkably, the most important factor is the relationship between farmers and buyers. The positive utility 
associated with knowing the buyer personally seems to outweigh the negative utility associated with entering into a contract in general, which is probably related to issues of trust.

In many developing countries, the role of modern supply chains involving contractual agreements between farmers and agribusiness firms or their agents is growing. Hence, the question of how smallholder farmers can be linked successfully to these emerging markets is of high policy relevance. Much recent work has analyzed factors that might potentially hinder smallholder participation, mostly focusing on transaction costs and financial and technical constraints. Our results suggest that concentrating on such constraints alone may result in an incomplete picture, because farmers' marketing preferences also matter. This should be considered more explicitly in future research.

For sweet pepper in Thailand, companies have started to establish own integrated production plants in peri-urban areas, partly because they find it difficult to source sufficient produce from smallholder farmers. Similar trends can also be observed for other high-value products and in other countries. Sometimes, integrated production by agribusiness companies can generate new employment opportunities for rural households, as was found by Maertens and Swinnen (2009) in Senegal. But this cannot always be expected; in Thailand, for instance, integrated sweet pepper production is very technology-intensive, with little use of unskilled manual labor. Hence, not integrating small farms into modern supply chains more successfully can be associated with lost opportunities for rural development.

Beyond addressing widespread market imperfections, which is certainly important, our results suggest that improving the relationship between farmers and buyers could also contribute to more widespread smallholder participation in contractual arrangements. Against this background, the fact that company representatives and intermediaries are often non-locals is not conducive. One approach could be to more explicitly involve local traders, who have established long-term relationships with farmers. Where this is not possible logistically, companies and intermediaries could try to improve ties with farmers through other trust-building mechanisms, such as more frequent personal interactions and more transparent pricing and grading procedures. 


\section{Implications of the expansion of modern retail structures for traditional markets: the case of wet markets in Thailand}

\subsection{Introduction}

The rapid expansion of modern retail structures in developing countries has recently gained much attention in the literature. In addition to studies describing and explaining this trend (Reardon et al., 2003, 2005; Traill, 2006), there is an emerging body of literature analyzing the effects of the 'supermarketization' (Reardon et al., 2005) on agro-food systems in developing countries. While a first strand of literature focuses on the impacts of the domestic food market transformation on smallholder farmers (Bignebat et al., 2009; Hernández et al., 2007; Timmer, 2009), a second strand looks downstream and investigates the impacts of the growing importance of supermarkets on consumers (Pingali, 2006; Asfaw, 2008; Neven et al., 2006; Stringer et al., 2009). Finally, an important topic of interest, but with far less empirical evidence, is the competition of modern retailers with the traditional retail sector, especially regarding 
wet markets. While some studies highlight the (negative) effects of an increasing number of modern retail outlets on local small-scale grocer's shops (Faiguenbaum et al. 2002; Hawkes, 2008; Ho, 2005; Natawidjaja et al. 2007; Reardon et al., 2010), only few studies examine the implications for wet markets (for an overview, see Minten and Reardon, 2008). This is explained by the fact that modern retail markets first focus on attracting consumers with an all-in-one shopping strategy coupled with particularly low prices for processed foods and staples, but they charge a higher price for fresh fruits and vegetables (FFV) than traditional retailers (Reardon and Berdegué, 2006). However, in an advanced development stage, modern retail markets start to mimic wet market situations in their stores, and although some barriers exist, e.g. the need for a continuous cool chain, the share of fresh produce sales as a percentage of total food sales in modern retail markets is increasing (D'Haese and van Huylenbroeck, 2005; Reardon and Berdegué, 2002; Reardon et al., 2010). Considering the multiple functions of wet markets - a major market outlet of smallholder farmers who might not be able to supply modern retail markets, the first place to shop for poor consumers, and an employment option for unskilled labor - it is, however, important to know how these markets can compete with modern retail formats. Suryadarma et al. (2007) document e.g. that in Indonesia, the number of wet markets located near modern retailers is decreasing.

Up to now it has been unclear how modern retail markets drive the expansion of the FFV section. Two major aspects are lower food prices and higher product quality. Due to procurement system modernization and economies of scale, modern retailers have gained cost advantages over traditional retailers; these advantages might be passed down to prices for fresh fruits and vegetables (Reardon et al., 2010). The scant literature on price differences for FFV shows that modern retail markets slowly become price competitive in fresh foods (Minten and Reardon, 2008). Other authors argue that modern retailers introduce quality standards (Balsevich et al., 2003; Henson and Reardon, 2005), which lead to the expectation that fruits and vegetables are more expensive and of higher quality. Yet little is known about the details of such quality standards and only few studies exist which examine how product quality has been reflected in product prices (Minten and Reardon, 2008). 
We aim to fill this research gap by analyzing the competition strategy in regard to product prices and qualities of different retail formats in Thailand, a country where modern retail structures are in an advanced stage of development. We implemented our research in Bangkok, where modern retail outlets were first established and FFV sections are fairly developed within these markets. Bangkok hosts a wide array of different market outlets ranging from traditional wet markets to modern super- and hypermarkets, thus representing an ideal case for our study. In our research, we focused on two different kinds of vegetables. The first is morning glory, a leafy vegetable that is commonly used for various Thai dishes. Morning glory has a strong reputation of being grown with a lot of pesticides, thus raising concerns for safety and quality. The second product is sweet pepper, a non-traditional vegetable that was introduced in Thailand only some 10 years ago, mainly to serve export and national modern retail markets. It however, nowadays trades on traditional retail markets as well.

In a first step, while drawing on secondary data, we give an overview about the development and the status of expansion of modern retail structures in Thailand. Based on primary data, we then analyze the competition strategy of modern retail markets. We do so by comparing observable product quality attributes and prices between modern retail and wet markets for the two selected vegetables. Finally, we employ hedonic price models to identify the effect of product quality attributes on product prices. We hypothesize that competition strategies vary between different modern retail formats, and we differentiate modern retail markets into super- and hypermarkets in our analysis. This gives us a more precise picture, which is an improvement in regard to earlier studies.

The remainder of the article is organized as follows: In the second section, we will give an overview about both the development of modern retail structures in Thailand and our database. In the following section, we compare the retail outlets of interest in regard to general market features as well as price and quality differences for sweet pepper and morning glory. Section four addresses the hedonic price models, which aim to explain the impact of various quality criteria on product prices. Section five concludes. 


\subsection{Background on modern retail markets in Thailand and database}

\subsubsection{The development of modern retail structures in Thailand}

Like many countries in Central America and other South-East Asian countries, modern retail structures were established relatively early in Thailand. A first step in this direction took place in 1964, when a Japanese investor opened a department store in Bangkok, which included a food market. In the 1980s and 1990s increasing per capita incomes, urbanization trends and female labor force participation spurred, among other things, the further development of modern retail structures. Several retail formats - supermarkets (first opened in 1972), convenience stores (first opened in 1989), hypermarkets (first opened in 1988), and large shopping centers including supermarkets (first opened in 1993) - were established, foremost in Bangkok and its surrounding suburbs. The major share in these businesses was held by Thai investors. However, due to the economic crises in the late 1990s and the countries`opening up to foreign direct investment, major parts of their businesses were sold to multinational retail chains. In 2007 the two leading supermarket chains were once again Thai-owned, whereas the three leading hypermarket chains belonged to foreign investors (TDRI, 2002; Tokrisna, 2006).

All five retail chains steadily increased their number of branches until 2009, as shown in Figure 5. Comparing the growth rates of supermarkets (Foodland and Tops) and hypermarkets (Big C, Tesco Lotus, Carrefour), we can see that overall, hypermarkets expanded more than supermarkets. In 2009 roughly 32\% more hyper- than supermarket branches existed, with Tesco Lotus having the most branches. Another difference between the two groups is the regional focus, which is depicted in Figure 6. These supermarket chains still have the most branches in Bangkok, whereas two of the hypermarket chains have fewer branches in Bangkok than in other areas of Thailand. That is, hypermarkets expand earlier to regions which are less urbanized or have lower average income levels; this can already be an indication that they focus on different income groups, or a broader range of income groups, than supermarkets. 
Figure 5: Leading super- and hypermarket chains in Thailand, 1996-2009

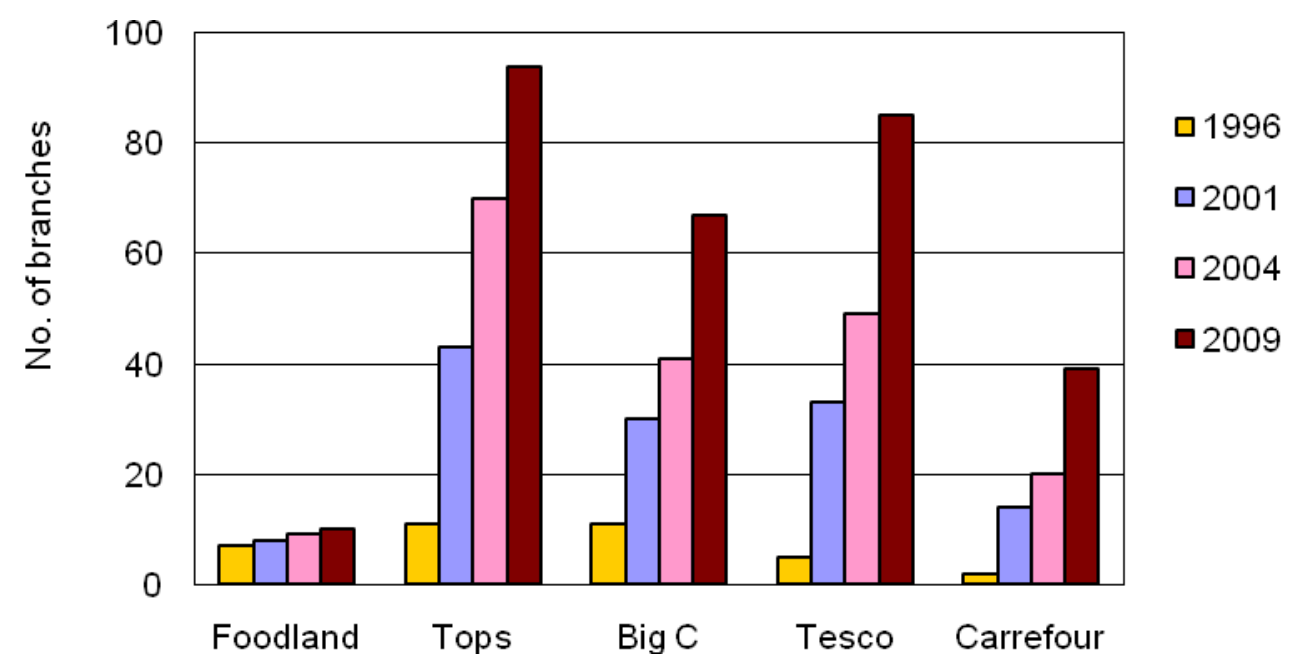

Source: TDRI, 2002; Tokrisna, 2006; websites: http://www.carrefour.co.th/eng/Map.aspx; http://www.bigc.co.th/en/stores/; www.foodland.co.th/home.htm; http://www.tops.co.th/main.html; http://www.tescolotus.com/left.php?lang=en\&menu=location_th\&data=searchlocation

The growth of modern retail markets described above is also reflected in the value of all retail trade of modern retailers. According to the TDRI (2002), sales increased from 249.1 billion Baht in 1997 to 635.4 billion Baht in 2001. In the same period, the value of traditional retail trade decreased, so that all in all, the share of modern retailers in all retail trade increased from $26.0 \%$ in 1997 to $53.2 \%$ in 2001 . Thus already in 2001 modern retail markets had half of the market share in total retail trade. Concerning retail food sales only, studies indicate market shares between 25\% (Vandeplas et al., 2009) and 35\% (Wiboonpongse and Sriboonchitta, 2004) in 2004. Keeping in mind the growing number of branches through 2009, it can be expected that the market share of the modern retail sector increased further, implying an ongoing decline in market shares of traditional retailers. A continuous downturn of traditional grocery shops has already been reported (Sirikeratikul, 2004; TDRI, 2002).

The FFV section in modern retail stores is steadily increasing (Wiboonpongse and Sriboonchitta, 2004), but precise figures only exist based on surveys of consumers. Suddeephong (2010) has shown that households in Bangkok spent $21.10 \%$ of their expenditures on fresh fruits from modern retail markets. In the case of expenditures for fresh vegetables, $26.35 \%$ is spent in modern retail outlets. The share of modern retail markets in the FFV section is lower than the share in food retail trade. This is 
in line with the findings from Reardon and Berdegué (2002) which show a relatively low share of modern retailers in the FFV segment in various countries in Central and South America, but nevertheless also indicate an increasing trend.

Figure 6: Spatial distribution of retail chain branches in Thailand, 2009

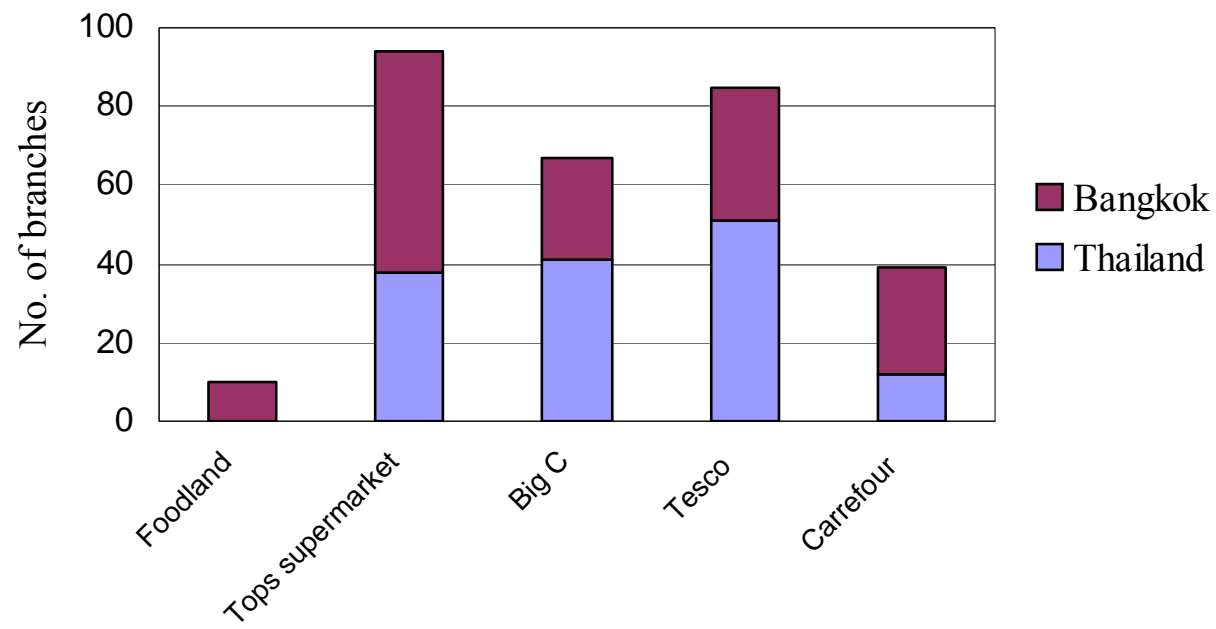

Source: http://www.carrefour.co.th/eng/Map.aspx; http://www.bigc.co.th/en/stores/; www.foodland.co.th/home.htm; http://www.tops.co.th/main.html; $\mathrm{http}: / /$ www.tescolotus.com/left.php?lang=en\&menu=location_th\&data=searchlocation

For our empirical study we conducted a survey of 43 market outlets in 17 districts of Bangkok between January and April 2009. As the primary purpose of this study is to compare competition strategies of different retail formats, the sampling was set up as follows: The two leading supermarket chains and three leading hypermarket chains were selected as modern retail outlets. As Tops has two different supermarket formats, Tops Supermarket and Tops Marketplace, we decided to treat them separately, so that in total six modern retail chains were differentiated. All super- and hypermarkets provide information about the number and addresses of all branches on their websites. In total, 122 branches of the six retail chains were in Bangkok in November 2008. We prepared a list of each chain's branches and then randomly sampled $20 \%$. This leads us to a sample 26 branches, consisting of 14 super- and 12 hypermarket branches in 17 districts, as in some cases several branches were in the same district. In detail, our supermarket sample consists of two branches of Foodland, eight branches of Tops Supermarket and four branches of Tops Marketplace. The hypermarket sample includes three, four and five branches of Big C, Tesco Lotus and 
Carrefour, respectively. For comparison reasons, the surveyed wet markets should be in the same districts as the modern retail branches. We therefore obtained a list of all registered wet markets per district in Bangkok from the Bangkok Metropolitan Administration. In the 17 districts of interest, there were 205 wet markets in 2007 (the most recent list was from 2007). We randomly sampled one wet market per district of interest.

In order to make data collection manageable we decided to focus on two products of the fresh vegetable segment. The first vegetable we chose was morning glory, a local leafy vegetable consumed in many different ways in various Thai dishes. Leafy vegetables in general account for around $44 \%$ of budget shares on vegetables of consumers in Bangkok (Suddeephong, 2010). The second vegetable we chose was sweet pepper, a non-traditional vegetable. Sweet pepper was introduced in Thailand only around ten years ago as a high-value product to be sold in modern retail outlets. However, it is nowadays more widely consumed and sold at traditional markets as well.

Price and quality data on the two products were collected in one week of each month for four consecutive months. In modern retail outlets, prices and quality data were collected for all morning glory and sweet pepper examples available. Several products from the same brand and/or at the same price offer were counted as one example. In wet markets, we randomly sampled $20 \%$ of the food stalls (or a minimum of two stalls in very small wet markets) which offered both sweet pepper and morning glory. In three markets, only one food stall was found which sold sweet pepper, so in these cases the minimum of 2 stalls could not be observed. Each month, the same food stalls were repeatedly visited to gather price and quality data. In total 39 market stalls were surveyed for morning glory and 28 were surveyed for sweet pepper. Some stalls sold sweet pepper as well as morning glory, so that in total 52 stalls were surveyed. Morning glory was always only sold at a single price at each stand. Sweet pepper however, was sometimes sold at different prices. In that case, observations were differentiated according to products of the same price category. In total we ended up with a sample size of 157 observations for morning glory on wet markets and 239 observations on modern retail markets. For sweet pepper our sample comprises 182 observations on wet markets and 195 in modern retail markets. 
Table 14: Quality attributes for morning glory and sweet pepper

\begin{tabular}{llll}
\hline Quality criteria morning glory & \multicolumn{3}{l}{ Level of quality } \\
\hline Freshness leaves & not good & good & very good \\
Freshness stem & not good & good & \\
Holes in leaves & no & few & $>25 \%$ \\
Color & normal green & light/dark green & \\
Roots & no & yes & \\
Quality criteria sweet pepper & & & none \\
\hline Skin wrinkles & $>25 \%$ & some parts & none \\
Skin spots & $>25 \%$ & some & \\
Variety & green & red & few parts different $>25 \%$ not pure \\
Color pureness & pure & too round/long & \\
Sweet pepper shape & yes & & \\
\hline
\end{tabular}

Source: Own investigation

Our survey is based on a structured questionnaire which was especially designed for this purpose. Some general information about the market and the observed market stall was collected, but the focus was on collecting data about product quality and price. In our study product quality is defined as a collection of observable quality criteria, as it is difficult to incorporate credence attributes in such a study. We obtained the quality criteria for the two vegetables of choice from focus group interviews with students as well as customer interviews at different markets. In both cases several samples of each product were shown to the group of customers, which they ranked according to product quality. Afterwards we discussed with the customers their rankings and the quality criteria they applied. These discussions led us to the quality attributes shown in Table 14. Additionally we collected data on other quality related aspects like product packaging, brand and label.

\subsection{Comparison of price and quality differences between market out- lets}

\subsubsection{Description and comparison of different market outlets}

Based on observations made during the survey, we will first give a brief characterization of the leading super- and hypermarket chains in Thailand. The two leading su- 
permarket chains are Foodland and Tops, the latter having two supermarket formats, namely Tops Supermarket and Tops Marketplace. Tops Supermarket was established in 1996, and in terms of product assortment (low price offers as well as branded and imported products), store location and design, one can conclude that the format was chosen to attract customers from various income groups. Tops Marketplace was only launched recently. Store design, location and product assortment (e.g. high-value and imported products like Swiss cheese) indicate a focus on high-income customers. Considering these same aspects for Foodland (with a wide range of imported goods and store design less modern than Tops Marketplace), one can see that it caters to foreign expatriates and ranges somewhere between the two Tops market formats. In all three supermarket chains, the FFV section is located at the entrance, but the FFV section of Foodland is smaller and with less product variety than both Tops market formats. Tops Marketplace offers by far the best product variety and most attractive product presentation.

The three most important hypermarket chains are Big C, Tesco Lotus and Carrefour. In regard to store location, not much difference could be found among the three hypermarkets. Concerning product assortment, store design and overall appearance, Carrefour and Tesco Lotus rank highest, while Big C lags behind. Moreover, Big C promotes itself with low prices and slogans like 'Guaranteed low price everyday' to attract price-sensitive customers; on the other hand Carrefour promotes its own internationally approved Quality line to signal food safety and attract health-conscious customers, especially in its FFV section. Tesco Lotus does not advertise an emphasis on price or quality. In all of these stores, the FFV section is located at the far end of the food section. Product variety and presentation of this section do not vary much, but Big $\mathrm{C}$ offers fewer products with specific labels, indicating the high quality of the respective products.

Table 15 compares the market features of the three retail formats. While column two to four display information per retail format, the fifth column shows the significance level for differences between the two modern retail formats.

Table 15: Comparison of various market features in 2009 (\%)

Wet Super- Hyper- Diff. super- and




\begin{tabular}{|c|c|c|c|c|}
\hline & market & market $^{\mathrm{a}}$ & market $^{b}$ & hypermarke \\
\hline \multicolumn{5}{|l|}{ General information } \\
\hline Integrated in shopping mall & 5.88 & $28.75^{*}$ & $100.00 * *$ & $* *$ \\
\hline Opening time $\mathrm{am}^{\mathrm{c}}$ & 4.30 & $7.30^{* *}$ & $9.00 * * *$ & \\
\hline Closing time $\mathrm{pm}^{\mathrm{c}}$ & 6.30 & $10.00^{* *}$ & $11.00 * * *$ & * \\
\hline Parking lot & 52.94 & $92.86^{* *}$ & $100.00 * * *$ & \\
\hline \multicolumn{5}{|l|}{ Store location } \\
\hline Location highway & 11.76 & 35.71 & $91.67 * * *$ & $* * *$ \\
\hline Location main street & 64.71 & 50.00 & $8.33 * * *$ & $* *$ \\
\hline Location side street & 23.53 & 14.29 & $0.00 *$ & \\
\hline \multicolumn{5}{|l|}{ Fresh fruit and vegetable section } \\
\hline Fresh produce & 79.41 & $23.46 * * *$ & $14.90 * * *$ & $* *$ \\
\hline Cooling facilities & 5.88 & $100.00 * * *$ & $100.00 * * *$ & \\
\hline Vegetables with a label & n.a. & 80.00 & 50.71 & $* * *$ \\
\hline Organic FFV available & n.a. & 64.29 & 33.33 & \\
\hline Market has low product variety & 17.65 & 21.43 & 8.33 & \\
\hline Market has normal product variety & 58.82 & 42.86 & 75.00 & * \\
\hline Market has high product variety & 11.76 & 35.71 & 16.67 & \\
\hline \multicolumn{5}{|l|}{ Characteristics of wet markets } \\
\hline Markets with label & 29.41 & & & \\
\hline Indoor & 88.24 & & & \\
\hline
\end{tabular}

Notes: $*$,***** displays a $10 \%, 5 \%$ and $1 \%$ significant level, respectively. Significant levels were obtained from a chi2-test and t-test, respectively.

${ }^{a}$ Significance levels in this column refer to the difference between supermarkets and wet markets.

${ }^{\mathrm{b}}$ Significance levels in this column refer to the difference between hypermarkets and wet markets.

${ }^{\mathrm{c}}$ Information here is not given in $\%$, but shows the average opening/closing time.

Source: Own observation

While wet markets are usually stand alone markets, super- and hypermarkets are significantly more often integrated into bigger shopping malls. The integration of supermarkets enables them to offer customers a wide range of shopping possibilities, even when they do not offer these products themselves. Hypermarkets, in contrast, are already a shopping complex as such: They exhibit a broad variety of product groups in their own stores, ranging from electronics to office equipment and even furniture. Moreover, hypermarkets include various food shops and some even incorporate playgrounds into their buildings. All these efforts aim to provide customers an 
all-in-one shopping opportunity, promoting shopping as a leisure time activity for the whole family. Although wet markets are often surrounded by some clothes stores or small grocery shops, they can hardly compete with the broad offers of modern retailers. With respect to opening hours, all market formats are open on average 14 hours a day, but super- and hypermarkets open and close significantly later than wet markets. Thus modern retail markets present an advantage to consumers who have to go shopping after work. Parking lots are significantly more common at modern retail markets than at wet markets, another advantage for modern retailers.

There is a great deal of diversity in terms of market accessibility. While wet and supermarkets are more often located on main streets, hypermarkets are mainly found on highways. This can be explained by the size of hypermarkets, as well as the zoning regulations of the Thai government. Both types of locations - on a highway outside the city centre, or on a main street, which is usually more central - can be advantageous and disadvantageous. Highways offer better access by car, as traffic jams in the city centre can be avoided, whereas markets located in residential areas are often within walking distance and thus easier to reach without a car.

As expected, the fresh produce section (including FFV, but also fish, meat and bakery products) makes up a significantly larger share in the wet markets than in the modern retail markets. Whereas $80 \%$ of the wet market area is dedicated to fresh produce, the market share in supermarkets is only around $23 \%$ and that of hypermarkets, at $15 \%$, is even lower. Interestingly, product variety is not significantly higher at modern retail markets. However, a great difference between the market formats is found with regard to product labels and the availability of organic products. The latter are not found at all in wet markets, whereas in nearly two thirds of supermarkets and one third of hypermarkets, organic fruits and vegetables are offered.

Product labels are a way of signaling product quality to consumers. The most important quality label in Thailand is the Q-label. Products with the Q-label attest that the farmer who produced them has a $\mathrm{GAP}^{7}$ certificate, i.e. the farmer implements certain production standards set up by the Ministry of Agriculture and Cooperatives in Thailand. Other food labels include the 'Food safety label', which was implemented be-

\footnotetext{
${ }^{7}$ GAP stands for Good Agricultural Practice.
} 
fore the Q-label, but is now being replaced by it, and the 'Toxin free label', which is no longer frequently found. Recently, some chains also introduced their own quality labels like the 'Carrefour Quality Line', which only comprises a limited number of products, however. In all modern retail branches, labeled products were found, but the share of labeled products is significantly higher in supermarkets than in hypermarkets. In wet markets, quality labels assigned to specific products were not found at all. However, $29 \%$ of the observed markets had the label 'Bangkok, city of clean food', which is a kind of quality label for wet markets. However, details about this label are not known. Cooling facilities are also hardly available on wet markets, and only one market with some refrigerated stalls was observed. In modern retail markets, it is a common standard to offer FFV in cooled shelves.

By means of the comparison of general market features we see that modern retail markets have some competitive advantages over wet markets with regard to convenience and product quality. However, only a few quality criteria (cooling and labeling) have been considered so far. Below, we will further explore quality differences among the retail formats, based on our examples of morning glory and sweet pepper.

\subsubsection{Comparison of quality differences}

Quality criteria for morning glory and sweet pepper can be grouped according to freshness and overall product appearance. The attributes for freshness are ranked from worst to best, whereas the other attributes cannot clearly be ranked as consumer preferences might differ.

In the case of morning glory, product freshness was measured by two criteria, the freshness levels of the leaves and the stem. Three other attributes cover the overall product appearance. For sweet pepper, skin spots and skin texture show the freshness of the product, and shape, color pureness and variety indicate general product attributes. In addition to the comparison of these inherent product attributes, we also considered the quality related product attributes of packaging, brand and label. The results are shown in Table 16 and 17. 
Table 16: Quality differences for morning glory by retail outlet

\begin{tabular}{|c|c|c|c|c|}
\hline Morning Glory & $\begin{array}{c}\text { Wet } \\
\text { market } \\
(n=155)\end{array}$ & $\begin{array}{l}\text { Super- } \\
\text { market }^{\mathbf{a}} \\
(\mathrm{n}=133)\end{array}$ & $\begin{array}{c}\text { Hyper- } \\
\text { market }^{\mathbf{b}} \\
(\mathrm{n}=106)\end{array}$ & $\begin{array}{c}\text { Diff. super- } \\
\text { and hyper- } \\
\text { market }\end{array}$ \\
\hline \multicolumn{5}{|l|}{ Freshness leaves } \\
\hline Not good & 22.93 & $3.76^{* * *}$ & 25.47 & $* * *$ \\
\hline Good & 61.51 & $74.44 * *$ & 63.21 & $*$ \\
\hline Very good & 15.92 & 21.80 & 11.32 & $* *$ \\
\hline \multicolumn{5}{|l|}{ Freshness stem } \\
\hline Not good & 15.29 & $4.51 * * *$ & 17.92 & $* * *$ \\
\hline Good & 84.71 & $95.49 * * *$ & 82.08 & \\
\hline \multicolumn{5}{|l|}{ Holes in leaves } \\
\hline None & 54.78 & $69.92 * * *$ & 55.66 & $* *$ \\
\hline few & 43.31 & $28.57 * * *$ & 39.62 & $*$ \\
\hline$>25 \%$ & 1.91 & 1.50 & 4.72 & \\
\hline \multicolumn{5}{|l|}{ Color } \\
\hline Dark/light green & 31.21 & 23.31 & 35.85 & $* *$ \\
\hline Normal green & 68.79 & 76.69 & 64.15 & \\
\hline \multicolumn{5}{|l|}{ Roots } \\
\hline Yes & 96.82 & $35.34 * * *$ & $89.62 * *$ & $* * *$ \\
\hline \multicolumn{5}{|l|}{ Package } \\
\hline Yes & 14.01 & $100.00 * * *$ & $80.19 * * *$ & $* * *$ \\
\hline \multicolumn{5}{|l|}{ Label } \\
\hline Yes & 0.00 & $93.98 * * *$ & $55.56 * * *$ & $* * *$ \\
\hline \multicolumn{5}{|l|}{ Brand } \\
\hline Yes & 0.00 & $99.25 * * *$ & $88.68 * * *$ & $* * *$ \\
\hline
\end{tabular}

Notes: $*, * *, * * *$ displays a $10 \%, 5 \%$ and $1 \%$ significant level, respectively. Significant levels were obtained from a chi2-test. ${ }^{a}$ Significance levels in this column refer to the difference between supermarkets and wet markets. ${ }^{\mathrm{b}}$ Significance levels in this column refer to the difference between hypermarkets and wet markets.

Source: Own observation

While supermarkets offer a significantly higher share of morning glory with fresh stems and fresh leaves, no significant difference is found between hyper- and wet markets. As product freshness decreases with longer shelf life, this indicates that 
supermarkets have the better means to control the shelf life of their products (e.g. faster turnover and cooling facilities) or that they simply do not sell products with a reduced freshness level.

In regard to the other attributes, supermarkets offer significantly more morning glory with the least amount of holes and without roots, compared to both other retail formats. Hypermarkets, compared to wet markets, also sell a significantly lower share of morning glory with roots, but not with fewer holes in the leaves. However, at $90 \%$, the share of morning glory sold with roots is very high in hypermarkets. No significant difference for color was found in any of the markets.

Considering the other quality related attributes, we see that supermarkets rank best for all attributes. In other words, supermarkets offer a significantly higher share of morning glory, which is packed, sold under a brand name or with a quality label, than both other retail formats. Indeed, all morning glory sold in the surveyed supermarket branches is packed and almost all morning glory has a label and a brand name. Hypermarkets rank second for all attributes and also show a significant difference to wet markets.

Findings for sweet pepper are similar, but the differences are not as clear. Super- and hypermarkets offer significantly higher shares of sweet pepper without wrinkles and lower shares of products with over $25 \%$ skin spots. This indicates that sweet pepper is fresher in modern retail markets. However, the general product attributes of sweet pepper do not vary significantly in any case.

For the other three product quality related attributes, the results are the same as for morning glory in the comparison of both modern retail formats with wet markets. Interestingly, however, in the case of sweet pepper, hypermarkets rank better than supermarkets and offer significantly more sweet pepper, which is packed, has a label or is sold with a brand name, but the latter difference is not significant. In both modern retail formats, the share of sweet pepper with the above attributes is lower than the share of morning glory with these attributes. 
Table 17: Quality differences for sweet pepper by retail outlet

\begin{tabular}{|c|c|c|c|c|}
\hline Sweet pepper & $\begin{array}{c}\text { Wet } \\
\text { market } \\
(n=182)\end{array}$ & $\begin{array}{c}\text { Super- } \\
\text { market }^{\mathbf{a}} \\
(\mathrm{n}=102)\end{array}$ & $\begin{array}{c}\text { Hyper- } \\
\text { market }^{\text {b }} \\
(n=93)\end{array}$ & $\begin{array}{c}\text { Diff. super- } \\
\text { and hyper- } \\
\text { market }\end{array}$ \\
\hline \multicolumn{5}{|l|}{ Skin texture } \\
\hline$>25 \%$ wrinkled & 27.07 & $3.92 * * *$ & $6.45 * * *$ & \\
\hline Few parts wrinkled & 36.46 & 42.16 & 26.88 & $* *$ \\
\hline Smooth & 36.46 & $53.92 * * *$ & $66.67 * * *$ & * \\
\hline \multicolumn{5}{|l|}{ Skin spots } \\
\hline$>25 \%$ & 6.63 & $0.00 * * *$ & $0.00 * *$ & \\
\hline Few & 49.17 & 49.02 & 48.39 & \\
\hline None & 44.2 & 50.98 & 51.61 & \\
\hline \multicolumn{5}{|l|}{ Variety } \\
\hline Green & 51.93 & 47.06 & 46.24 & \\
\hline Red sweet pepper & 48.07 & 52.94 & 53.76 & \\
\hline \multicolumn{5}{|l|}{ Color } \\
\hline $25 \%$ colored differently & 6.08 & 3.92 & 4.3 & \\
\hline few parts colored differently & 23.76 & 20.59 & 17.2 & \\
\hline pure & 70.17 & 75.49 & 78.49 & \\
\hline \multicolumn{5}{|l|}{ Shape } \\
\hline Not good & 6.63 & 6.86 & 6.45 & \\
\hline Good & 17.13 & 21.57 & 16.13 & \\
\hline Very good & 76.24 & 71.57 & 77.42 & \\
\hline \multicolumn{5}{|l|}{ Package } \\
\hline Yes & 3.31 & $48.04^{* * *}$ & $60.22 * * *$ & $*$ \\
\hline \multicolumn{5}{|l|}{ Label } \\
\hline Yes & n.a. & 14.71 & 17.20 & \\
\hline \multicolumn{5}{|l|}{ Brand } \\
\hline Yes & n.a. & 51.96 & 65.59 & $*$ \\
\hline
\end{tabular}

Notes: $*, * * * * *$ displays a $10 \%, 5 \%$ and $1 \%$ significant level, respectively. Significant levels were obtained from a chi2-test. ${ }^{a}$ Significance levels in this column refer to the difference between supermarkets and wet markets. ${ }^{b}$ Significance levels in this column refer to the difference between hypermarkets and wet markets.

Source: Own observation 
In sum, our results show that modern retail markets offer higher quality for the observed products than wet markets. This was also shown by Minten and Reardon (2008) for rice and tomatoes in Madagascar. Moreover, they attach additional attributes, like label or brand, to the product, which can further upgrade the product and signal some kind of quality to the consumer. Differences between the two modern retail formats suggest that supermarkets are more concerned with quality than hypermarkets are.

\subsubsection{Comparison of price differences}

As stated above, price is an important competitive instrument. We compared the prices for morning glory and sweet pepper in the three retail formats. Based on our findings in the previous section, we expected to find higher product prices in modern retail markets. Table 18 shows the average product prices per month, as well as the average price for the entire survey period. As the number of observations per month is rather small in some cases, we did not take a detailed look at the disaggregated data. In the case of sweet pepper, we distinguish between green and red sweet pepper, because they are nearly always sold for different prices, with the red variety usually more expensive.

Confirming our expectations, both modern retail formats are significantly more expensive than wet markets. In addition, supermarkets are generally more expensive than hypermarkets, though the difference is not always significant. When looking at the lowest product price available in a respective market, we found that the lowest supermarket price for all three products is still higher than the price in wet markets, while hypermarkets have the lowest price for at least one product.

Our results show that neither modern retail format is price competitive with wet markets. Moreover, the increases in price at modern retail markets show the same pattern as the quality ranking above. This is, supermarkets offer the highest quality as well as the highest prices, followed by hypermarkets and then wet markets. However, the descriptive statistics do not enable us to show whether the prices are determined by quality attributes. This will be explored in the next section. 
Table 18: Product prices per market outlet in Baht $/ \mathrm{kg}$

\begin{tabular}{|c|c|c|c|c|c|c|c|}
\hline \multirow{2}{*}{ 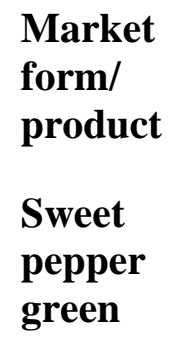 } & \multicolumn{2}{|c|}{ Traditional } & \multicolumn{2}{|c|}{ Supermarket $^{\mathrm{a}}$} & \multicolumn{2}{|c|}{ Hypermarket $^{b}$} & \multirow{2}{*}{$\begin{array}{c}\text { Diff. super- } \\
\text { and hyper- } \\
\text { market }\end{array}$} \\
\hline & price/kg & obs. & price/kg & obs. & price/kg & obs. & \\
\hline Jan & 102.33 & 24 & $156.54 * * *$ & 11 & $148.28 * * *$ & 14 & \\
\hline Feb & 92.08 & 24 & $156.73 * * *$ & 11 & $164.9 * * *$ & 10 & \\
\hline Mar & 118.10 & 21 & $160.16^{* * *}$ & 12 & 136.95 & 8 & \\
\hline Apr & 109.42 & 25 & $186.13 * * *$ & 14 & $173.72 * * *$ & 11 & $*$ \\
\hline Average & 105.12 & 94 & $166.12 * * *$ & 48 & $156.54 * * *$ & 43 & \\
\hline \multicolumn{3}{|c|}{ Price increase (\%) } & 58.03 & & \multicolumn{2}{|l|}{48.92} & 5.77 \\
\hline $\begin{array}{l}\text { Sweet } \\
\text { pepper re }\end{array}$ & price/kg & obs. & price/kg & obs. & price/kg & obs. & \\
\hline Jan & 151.45 & 20 & $186.00 * *$ & 9 & $180.41 * *$ & 14 & \\
\hline Feb & 109.13 & 23 & $180.30 * * *$ & 15 & $172.28 * * *$ & 13 & \\
\hline Mar & 128.13 & 24 & $188.55 * * *$ & 16 & $169.46^{* * *}$ & 11 & $*$ \\
\hline Apr & 133.45 & 20 & $221.79 * * *$ & 14 & $206.09 * * *$ & 12 & $* * *$ \\
\hline Average & 129.69 & 87 & $194.45 * * *$ & 54 & $182.05 * * *$ & 50 & \\
\hline \multicolumn{3}{|c|}{ Price increase (\%) } & 49.93 & & \multicolumn{2}{|l|}{40.37} & 6.38 \\
\hline $\begin{array}{l}\text { Morning } \\
\text { Glory }\end{array}$ & price/kg & obs. & price/kg & obs. & price/kg & obs. & \\
\hline Jan & 26.59 & 38 & $99.2 * * *$ & 33 & $75.95 * * *$ & 22 & $* * *$ \\
\hline Feb & 19.21 & 41 & $99.87 * * *$ & 34 & $60.83 * * *$ & 27 & $* * *$ \\
\hline Mar & 21.12 & 40 & $103.20 * * *$ & 33 & $67.62 * * *$ & 32 & $* * *$ \\
\hline Apr & 24.51 & 38 & $98.49 * * *$ & 33 & $69.07 * * *$ & 25 & $* * *$ \\
\hline Average & 22.77 & 157 & $100.19 * * *$ & 133 & 67.96*** & 106 & \\
\hline \multicolumn{3}{|c|}{ Price increase (\%) } & 340.01 & & 198.46 & & 32.17 \\
\hline
\end{tabular}

Notes: $* * *, * * *$ displays a $10 \%, 5 \%$ and $1 \%$ significant level, respectively. Significant levels were obtained from a t-test.

${ }^{a}$ Significance levels and price increase in this column refer to the difference between supermarkets and wet markets.

${ }^{\mathrm{b}}$ Significance levels and price increase in this column refer to the difference between hypermarkets and wet markets.

Source: Own observation 


\subsection{Price premia for market outlet and product quality}

\subsubsection{Model specification}

Economic hedonic models are based on the theory of consumer choice and follow the idea that product prices can be decomposed into values for individual product attributes (Lancaster, 1966; Ladd and Savannunt, 1976). In our study, we employed hedonic modeling to measure the effect of quality attributes associated with a particular vegetable on the price of each respective vegetable.

In the first step, we conducted a Chow-test to confirm that the data from different retail formats can be pooled (Wooldridge, 2009). For both products the results showed that data cannot be pooled from traditional and modern retail markets, but it can be pooled from super- and hypermarkets. This leads us to two different models for each product. We nevertheless estimated a pooled model for each product, but only to show the price effect of modern retail markets, which is not possible in the separate models.

The dependent variable in all models is the price per $\mathrm{kg}$ of product, and the independent variables are the inherent and related product quality attributes described above. The latter differ slightly according to the market observed. Dummy variables for brand and hypermarkets are only included in models that explain the pricing in modern retail markets, as they are not relevant on wet markets. Due to a limited number of observations, packaging was not included in the wet market model for sweet pepper. For inherent product quality attributes when the number of observations was rather low for a specific attribute level, or when no attribute level was significant, we summarized observations in two dummy variables instead of three. For morning glory, this was done for the variable holes in leaves, and for sweet pepper, this was performed for the variables for color pureness, skin spots and product shape, as well as skin texture in the model for modern retail markets. We additionally included dummies for the month of observation in all models as well as a variable that captures the monthly average per capita income on a district level. The income data is from 2008; it was obtained from the Thailand National Statistics Office. The monthly per capita income is included to reflect a possible relation between one area's living standard and the market price. 
Hedonic models can take various functional forms. Following Edmedeas (2007) and Ward et al. (2008), we tested the model specification for each model by employing a Box-Cox transformation. We ran all models with the specification supported by the Box-Cox transformation as well as with a linear specification. However, the difference in magnitude or in the level of significance between the models is only slight, so that, for reasons of comparability, we only show the results of the nontransformed linear specifications.

\subsubsection{Estimation results}

We are first of all interested to see whether the general price differences between wet and modern retail markets are also reflected in the hedonic price models. Table 19 shows the results from the pooled models. Only the results for the dummies which demonstrate an effect of modern retail markets are shown; the effects of quality attributes are discussed in the section on product and market specific models. Holding all the other variables constant, both products are sold at significantly higher prices in super- and hypermarket compared to wet markets. In both models, the coefficient for hypermarkets is smaller than that for supermarkets, indicating that increases in price in hypermarkets are lower than in supermarkets.

Table 19: Hedonic price regression (pooled regression)

\begin{tabular}{lcccc}
\hline & \multicolumn{2}{c}{ Morning Glory } & \multicolumn{2}{c}{ Sweet pepper } \\
\cline { 2 - 5 } Variable & Coefficient & $\begin{array}{c}\text { Standard } \\
\text { Error }\end{array}$ & Coefficient & $\begin{array}{c}\text { Standard } \\
\text { Error }\end{array}$ \\
\hline Supermarket (dummy) & $27.87^{* * *}$ & 8.01 & $62.89 * * *$ & 5.19 \\
Hypermarkets (dummy) & $14.74 * *$ & 7.21 & $49.04^{* * *}$ & 5.63 \\
\hline
\end{tabular}

Notes: ****** displays a $10 \%, 5 \%$ and $1 \%$ significant level, respectively. The dependent variable is price in Baht $/ \mathrm{kg}$.

Source: Own calculations

Tables 20 and 21 show the results for the separate models for morning glory and sweet pepper. In wet markets, only one of the inherent product attributes has a significant effect on product price: The freshness level of the leaf. However, a significant positive effect is only found for leaves which are very fresh, compared to leaves which are not fresh at all. Leaves with an ordinary level of freshness do not show a 
significant price effect. In contrast, a significant price effect is found for three inherent product attributes in modern retail markets. The level of freshness of the leaf affects the price the same way as it does in wet markets. Additionally, few and more holes in the leaves, compared to leaves without any holes, increase the price. While this might be surprising at a first glance, it can be explained by the ambivalent consumer opinion about this attribute. Some consumers argue that holes in the leaves are an indicator for less pesticide usage, so they would opt for a product with more holes. Roots also significantly affect prices: When morning glory roots are cut, the vegetable is sold for a higher price.

In both models, the packaging and label have a significant and positive effect on the price. In the case of modern retail markets, the variable label refers to the observed product, while for wet markets it refers to the fact that a wet market has a quality label (as explained in chapter 3.1). In the model for modern retail markets, we moreover find that hypermarkets significantly decrease the product price, which confirms our earlier findings. Interestingly, all dummies capturing the month of observation are negative and significant in the model for wet markets, but no significant effect is found at modern retail markets. Price fluctuations reflect seasonality. Lower price fluctuations in modern retail markets show that these markets can better control seasonality. Long-term agreements with suppliers and restricted access to these markets are explanations for this. The income variable is also only significant for wet markets. Thus, keeping all other factors constant, wet markets have higher prices for morning glory in districts with higher monthly per capita income. As wet markets are not organized in chains, it is not surprising that they adapt their prices according to the area in which they are located. For modern retail chains, this option only exists to a limited extent, e.g. for special product offers.

Results for sweet pepper differ less between the wet and modern retail markets. In both models, the same two inherent product attributes affect the price. Red sweet pepper is, as expected, more expensive than the green variety, and sweet pepper with smooth skin has a higher price. Interestingly, none of the other attributes significantly affects the price. In contrast to the morning glory findings, presence of a label only shows a significant and positive effect at wet markets. However, packaging, which was now only included in the model for modern retail markets, again shows a 
significant positive price effect. On the other hand, hypermarkets once again decrease the price significantly.

Table 20: Hedonic price regression for morning glory

\begin{tabular}{|c|c|c|c|c|c|c|}
\hline \multirow[b]{2}{*}{ Variable } & \multicolumn{3}{|c|}{ Wet Markets } & \multicolumn{3}{|c|}{ Modern Markets } \\
\hline & $\begin{array}{l}\text { Coeffi- } \\
\text { cient }\end{array}$ & $\begin{array}{l}\text { Std. } \\
\text { error }\end{array}$ & $\begin{array}{l}\% \text { price } \\
\text { increase }\end{array}$ & $\begin{array}{l}\text { Coeffi- } \\
\text { cient }\end{array}$ & $\begin{array}{l}\text { Std. } \\
\text { error }\end{array}$ & $\begin{array}{l}\text { \% price } \\
\text { increase }\end{array}$ \\
\hline Hypermarket (dummy) & & & & $-8.58^{*}$ & 5.03 & \\
\hline Brand (dummy) & & & & 16.25 & 9.88 & \\
\hline Packaging (dummy) & $2.98 * *$ & 1.42 & 13.10 & $15.89^{*}$ & 8.43 & 18.51 \\
\hline Label (dummy) & $2.26^{* *}$ & 1.13 & 9.92 & $29.91 * * *$ & 5.75 & 34.83 \\
\hline $\begin{array}{l}\text { Freshness leaves: } \\
\text { good (dummy) }\end{array}$ & 2.33 & 1.49 & & 3.39 & 7.04 & \\
\hline $\begin{array}{l}\text { Freshness leaves: } \\
\text { very good (dummy) }\end{array}$ & $3.86^{* *}$ & 1.87 & 16.94 & $20.95 * *$ & 9.11 & 24.39 \\
\hline $\begin{array}{l}\text { Freshness stems: } \\
\text { good (dummy) }\end{array}$ & 2.10 & 1.77 & & 0.47 & 7.22 & \\
\hline $\begin{array}{l}\text { Holes in leaves } \\
\text { (dummy) }\end{array}$ & -1.23 & 0.99 & & $12.63 * * *$ & 4.44 & \\
\hline $\begin{array}{l}\text { Color: normal green } \\
\text { (dummy) }\end{array}$ & 0.33 & 1.06 & & -0.99 & 4.56 & \\
\hline Roots: no (dummy) & 0.97 & 3.10 & & $11.80 * *$ & 4.77 & \\
\hline $\begin{array}{l}\text { Average income } \\
\text { (in } 1.000 \text { Baht) }\end{array}$ & $1.12 * * *$ & 0.22 & & 0.47 & 0.71 & \\
\hline February (dummy) & $-8.29 * * *$ & 1.35 & & -2.23 & 5.73 & \\
\hline March (dummy) & $-6.80 * * *$ & 1.40 & & 0.34 & 5.57 & \\
\hline April (dummy) & $-2.93 * *$ & 1.38 & & -2.19 & 5.66 & \\
\hline Constant & $10.93 * * *$ & 2.61 & & 17.92 & 13.48 & \\
\hline F-statistics & $8.60 * * *$ & & & $11.62 * * *$ & & \\
\hline
\end{tabular}

Notes: *,***** displays a $10 \%, 5 \%$ and $1 \%$ significant level, respectively. The dependent variable is price in Baht $/ \mathrm{kg}$. ${ }^{\mathrm{a}}$ All variables, except for average income, are dummy variables.

Source: Own calculations

Monthly price fluctuations are smaller compared to morning glory, as only the dummy variable for February proved to be significant in wet markets. Fluctuations are, however, also found in the model for modern retail markets, where the dummy 
for April shows a significant effect. The only significant influence of monthly average per capita income is on prices in wet markets.

Table 21: Hedonic price regression for sweet pepper

\begin{tabular}{|c|c|c|c|c|c|c|}
\hline \multirow[b]{2}{*}{ Variable $^{\mathrm{a}}$} & \multicolumn{3}{|c|}{ Wet Markets } & \multicolumn{3}{|c|}{ Modern Markets } \\
\hline & Coefficient & $\begin{array}{l}\text { Std. } \\
\text { error }\end{array}$ & $\begin{array}{c}\text { \% price } \\
\text { increase }\end{array}$ & Coefficient & $\begin{array}{l}\text { Std. } \\
\text { error }\end{array}$ & $\begin{array}{c}\text { \% price } \\
\text { increase }\end{array}$ \\
\hline Hypermarket & & & & $-13.67 * * *$ & 4.43 & \\
\hline Brand & & & & -3.13 & 5.48 & \\
\hline Packaging & & & & $18.58 * * *$ & 5.45 & \\
\hline Label & $14.48 * * *$ & 4.67 & & -10.19 & 6.84 & \\
\hline Skin wrinkles: few & $15.07 * *$ & 5.98 & 12.89 & & & \\
\hline Skin wrinkles: no & $15.51 * *$ & 6.41 & 13.27 & & & \\
\hline $\begin{array}{l}\text { Skin texture: very } \\
\text { good }\end{array}$ & & & & $10.41 * *$ & 5.19 & 5.92 \\
\hline Skin spots: no & -4.47 & 5.03 & & 2.70 & 5.27 & \\
\hline Sweet pepper: red & $23.61 * * *$ & 4.52 & 20.19 & $28.29 * * *$ & 4.37 & 16.08 \\
\hline Color: pure & -5.11 & 5.09 & & 0.65 & 5.63 & \\
\hline Shape: sweet pepper & 4.94 & 5.62 & & 3.85 & 5.23 & \\
\hline $\begin{array}{l}\text { Average income } \\
\text { (in } 1.000 \text { Baht) }\end{array}$ & $2.87 * *$ & 1.12 & & -0.79 & 0.77 & \\
\hline February & $-26.81 * * *$ & 6.51 & & 0.87 & 6.42 & \\
\hline March & 0.80 & 6.79 & & -2.51 & 6.52 & \\
\hline April & -2.63 & 6.89 & & $27.76 * * *$ & 6.32 & \\
\hline Constant & $66.12 * * *$ & 15.09 & & $147.40 * * *$ & 14.25 & \\
\hline F-statistics & $6.97 * * *$ & & & $8.59 * * *$ & & \\
\hline
\end{tabular}

Notes: *,***** displays a $10 \%, 5 \%$ and $1 \%$ significant level, respectively. The dependent variable is price in Baht $/ \mathrm{kg} .{ }^{\mathrm{a}}$ All variables, except for average income, are dummy variables.

Source: Own calculations

The third columns in Table 20 and 21 show the percentage price increase of the significant product attributes, calculated from the average prices shown in Table 18. Comparing the increases in price for the attributes, which are significant in both models, we see that modern retail markets have higher quality premiums for all three attributes in the case of morning glory. In contrast, the two variables, which are sig- 
nificant in both models for sweet pepper, have a larger quality premium in wet markets. However, in wet markets the percentage increase in price for sweet pepper lies in the same range than for morning glory. Interestingly, the increase in price in modern retail markets is less for sweet pepper than for morning glory. This can again be explained by the fact that sweet pepper is already sold for a very high price in modern retail markets, so that price increases cannot be as high for cheaper products.

In sum, the results from the hedonic price models show that quality differences are reflected in product prices. This was also found by Vandelpas et al. (2009) for rice and tomato in Madagascar and India. Furthermore, product quality not only comprises inherent product attributes, but also other attributes which consumers might value similarly to quality. While differences in product prices can be partially explained by quality differences, results from the pooled model additionally show that despite any quality differences, super- and hypermarkets have higher product prices. This shows that consumers attach some value to shopping in modern retail markets, as they are willing to pay the higher prices charged there.

\subsection{Conclusions}

We have analyzed the competition between wet markets and modern retail markets in regard to product prices and quality in Thailand. Since the 1990s, modern retail markets have expanded in Thailand, constantly increasing their number of branches as well as market share of overall retail sales. Accordingly, discussions about the impact on the traditional retail sector have taken place. Considering the multiple functions of wet markets and the increasing share of the FFV segment in modern retail markets, we focused on two different kinds of vegetables, namely morning glory and sweet pepper. Our comparison of product prices and quality among the three markets has shown that neither super- nor hypermarkets are price competitive with wet markets. However, super- and hypermarkets offer higher product quality, and the difference between super- and wet markets is greater than the difference between hyper- and wet markets. We can conclude from this comparison that supermarket chains focus on middle to high income customers and compete on the basis of premium products. Hypermarkets, in contrast, compete with wet markets by using a combination of higher quality with relatively low prices to attract middle and lower 
income customers. These findings suggest that the three market formats have up to now acted more as supplements to each other than as competitors.

Nevertheless two important questions have to be raised: First, are wet markets pleased with their role of mostly serving low-income customers; and second, how long will wet markets remain price competitive? Although modern retail markets might continue to have higher average prices, the comparison of the lowest price available already shows that hypermarkets offer the lowest price for one of the three observed products. In the future, both modern retail formats might continue to diversify their product offers and add low-price products to their product portfolio to attract more customers.

The results from the hedonic price models show that quality is reflected in prices and certain quality attributes significantly increase product prices. This shows that consumers value specific quality attributes and are willing to pay for them. The fact that these high quality products are primarily sold by super- and hypermarkets shows that they react better to changing consumer preferences and adapt their product assortments accordingly. The pooled model, which additionally shows the price effect of modern retail outlets, highlights that despite any quality differences, prices are higher in super- and hypermarkets compared to wet markets. This finding suggests that modern retail outlets do offer value for consumers. Keeping in mind the westernization of lifestyle in Bangkok, this finding is not surprising. Modern retail outlets are currently in fashion, despite their higher prices. For wet markets this means that consumers from the middle and upper income classes are leaving those markets to go shopping in modern retail outlets. Therefore, wet markets are not benefiting from overall economic growth. This will also have an impact on the development of rural economies. Wet markets are still the major market outlet for smallholder farmers, since not all of the farmers are able to fulfill the requirements of modern retail markets. If wet markets do not reap benefits from overall economic growth, the majority of smallholder farmers are also unlikely to benefit. It is therefore necessary that wet markets also adapt to changing consumer demands.

A first step in this direction is to increase the overall attractiveness of wet markets. They have to be a clean, well-organized place where people like to go shopping. Parking lots are also important. Up to now, most wet markets still exhibit a (very) 
traditional style, however, some positive examples of modern wet markets were also found in the survey. Market modernization can be implemented by traders only to a limited extent; it needs to be supported by the government, including government funding.

Second, wet markets have to increase their product quality to attract qualityconcerned customers. While better shelf life management and product labels are not easily implemented, offering additional morning glory without roots, or packaging part of the product, can be implemented immediately. In the long term, wet markets, however, have to strengthen their supply chains, to better communicate consumer preferences to farmers and thus ensure the delivery of appropriate products. This also ensures that an upgrade of wet markets will enable an upgrade for smallholder farmers with positive effects for rural development. 


\section{Conclusions}

Modern retail structures are expanding rapidly in developing countries and initiating transformation processes throughout the entire agro-food system. Thus, stakeholders in all stages of agricultural supply chains are being affected by this trend. One group of particular interest is smallholder farmers. First of all, this group is directly affected by changing market structures, and secondly, they require special consideration because they often belong to the poorest population group in any given country. To fully assess the implications of agro-food system transformations for this particular group, a comprehensive research approach is needed, and a great variety of aspects must be taken into account.

This study is based on the example of Thailand, a country where the transformation of agro-food systems is already in an advanced stage, yet nevertheless still dynamic. The overall aim of this study was to explore some of the issues of agro-food system transformations which have so far received little or no consideration in the agricultural economics literature. Our goal was to contribute to a better understanding of how smallholder farmers are affected by transformation processes and to show how they can benefit from changing market structures. 
More precisely, we aimed to answer the following three research questions. (1) which spillover effects can be expected from supermarket expansion and how can smallholder farmers benefit from these, (2) how far are changing institutional arrangements between farmers and buyers determinants for the integration of smallholder farmers into modern retail structures, and (3) what are the implications of supermarket expansion for wet markets, which are still the major market outlet for smallholder farmers?

Our case study of Thailand has shown that modern retail markets offer the possibility to introduce exotic products which were neither previously traded nor locally produced. When the climate and other conditions were favorable, local farmers were able to adopt such a product innovation - in our case sweet pepper - successfully. Moreover, spillover effects of the following form were observed: While sweet pepper was initially introduced to serve modern retail markets, the product gained wide popularity over time and is now also traded on more traditional wholesale and retail markets. The latter are still the most important market outlet for smallholder farmers; when a product innovation arrives at these markets, the greatest number of farmers can benefit from it. Our impact analysis has confirmed this assumption and shown that the adoption of sweet pepper cultivation contributed significantly to higher household incomes. However, the supply of sweet pepper to modern supply chains does not lead to higher incomes than when it is distributed to traditional markets. Thus, positive spillovers exist as farmers can benefit from the expansion of modern retail markets, even without directly supplying these markets. Nevertheless, our duration analysis has shown that farmers are still confronted with some constraints. These are not the result of the extensive requirements and strict regulations of modern retail markets, but reflect some of the general disadvantages which smallholder farmers face. Poor infrastructure and transport conditions, and limited access to market information, constituted serious adoption constraints in the beginning, slowing down the adoption process. In other words, farmers who are disadvantaged remain disadvantaged and are less likely to benefit from product innovations.

Although modern retail markets do not offer significantly higher benefits in our case, further market differentiation can be expected in the future, and there are other examples which show positive income effects from supplying modern retail markets. 
So from a development perspective, the question as to how smallholder farmers can access these market segments on a wider scale must not be overlooked. While transaction costs and financial and technical constraints indeed exist, institutional arrangements between farmers and buyers also need to be considered, as the changing procurement systems and strict product requirements of modern retail markets require stronger vertical relationships between buyers and suppliers.

For this reason we compared institutional arrangements, with special consideration devoted to the contracts between sweet pepper farmers and buyers in traditional and modern market channels. We have found significant differences between the marketing channels, e.g. modern retail markets are more likely to enforce contracts and provide inputs on credit. Moreover, some of the observed differences have influenced farmers' market channel choices. While output prices are of importance, farmers also value other factors, such as access to inputs, credit and information, as well as independence and flexibility. Results from the choice experiment with farmers have confirmed these findings. They have revealed that farmers generally prefer non-contract marketing options, but that certain factors, like the provision of inputs and credit, are clearly increasing the attractiveness of contracts. Remarkably, the most important factor is the relationship between farmers and buyers. The positive utility associated with having a personal relationship with the buyer seems to outweigh the negative utility associated with entering into a contract in general. Company representatives and intermediaries are often non-locals, a factor which does not increase the participation of smallholder farmers in modern retail markets.

Although modern retail markets are expanding rapidly, traditional wholesale and retail markets remain the most important market outlet for smallholder farmers. It is therefore also important to know the implications that the expansion of modern retail structures will have on traditional markets, and in particular, on wet markets. We therefore explored the competition strategy of modern retail formats with regard to product prices and observable product quality attributes. Our descriptive comparison of these two aspects among wet, super- and hypermarkets has shown that neither super- nor hypermarkets are price competitive with wet markets. However, both modern retail formats offer higher product quality. Our hedonic price models have revealed that quality premiums exist in all three market forms. Moreover, we have 
found that despite any quality differences, prices in super- and hypermarkets are higher than in wet markets. All in all, our results have suggested that supermarket chains focus on middle to high income customers, while hypermarkets use a combination of higher quality and relatively low prices to attract middle and, to some extent, lower income customers. The modern retail markets ' focus on middle and high income customers suggests that they have mostly supplemented wet markets, as opposed to competing with them. However, these findings also show that modern retail markets have reacted faster to the increasing consumer demand for high quality products, and they are thus reaping most of the benefits from overall economic growth. In order to benefit from the new income earning opportunities, wet markets need to better adapt to changing consumer demands to then become attractive shopping places for customers of the middle and upper income strata.

The findings from our three particular research questions, and observations made during the field surveys, enable us to draw some conclusions about the wider implications of the transformation of agro-food systems on the livelihood of smallholder farmers in Thailand. In the current situation modern retail markets do not appear to contribute much to the improvement of smallholder farmers' livelihood. There are indeed some farmers who benefit from supplying modern retail markets, and there are other farmers who benefit through spillover effects. Moreover, further spillover effects than those we have considered can be considered, e.g. labor market effects. However, the majority of smallholder farmers, and in particular, the lowest tier of this group, is unlikely to benefit. Due to the extensive requirements modern retail markets ask of their suppliers, and in particular, to these markets' changing procurements systems, smallholder farmers are less likely to supply these markets, either directly or through intermediaries. This raises the question, who can if not smallholder farmers, supply modern retail markets and reap the assumed benefits from modern retail structures. It is often argued that in dualistic agricultural structures, modern retail markets tend to purchase from large-scale farmers. However, only few details about the participants at the individual stages of modern retail markets exist. Managers of modern retail markets rarely provide information about their suppliers, and it is difficult to accurately reconstruct trade patterns. In Thailand, however, one could observe that a new group of farmers has been established, a group which solely 
focuses on supplying modern retail markets. It would be better to refer to these farmers as 'farm-managers', since they do not run farms in the traditional way, but rather set up an agricultural enterprise in the $100 \mathrm{~km}$ radius around Bangkok. These farmmanagers use state of the art technologies, e.g. intensive horticulture production in green houses, which decouples agricultural production from weather conditions, so that seasonality effects can be reduced and production cycles can be well planned and managed. This enables these enterprises to plan well in advance and supply modern retail markets the desired product quantity and quality in Bangkok all year round. Their proximity to Bangkok is yet another advantage. Smallholder farmers can hardly compete with this kind of agricultural production, and there are few reasons for modern retail markets to choose smallholder farmers over such agribusinesses.

One strategy which would nevertheless encourage the widespread participation of smallholder farmers would be to provide incentives for modern retail markets to source from these farmers. Social reputation is one potential incentive which could be visualized with a label demonstrating the 'social sourcing strategy' of modern retail markets. It remains questionable, however, how appealing this aspect would be to consumers in developing and emerging economies. As the Fair Trade movement in Europe has shown, it is more likely that these products would only serve a niche market, so this would not be practical for the majority of smallholder farmers.

A more focused support of smallholder farmers would probably achieve better results. For a long time, the main focus was on helping farmers improve their production skills, while marketing skills were forgotten. Although product quality is crucial, we have found that strategic marketing is just as important. Thus, farmers also require training in management and marketing skills. A pre-condition for these measures, however, is providing the farmers with better access to markets. In order to achieve this, the government must take responsibility for providing connections between rural areas and urban centers: This includes the maintenance and establishment of road infrastructure as well as providing public transport and offering improved market information systems. Farmers need to be aware of ongoing changes to be able to react. 
The farmers can also actively work on their own to increase their chances of participating in modern retail structures. One example in which farmers can overcome some of the constraints they face as individuals is to form groups or cooperatives.

Another strategy is to support not only smallholder farmers, but also traders who link farmers to markets. Company representatives and other intermediaries who connect farmers to modern retail markets are often non-locals; as discussed above, non-locals could have a negative influence on the integration of smallholder farmers in modern retail structures. Local village traders, who have always supplied traditional markets, thereby become the bottleneck in the process of widespread integration of smallholder farmers. These traders have already established relations of mutual trust with farmers. Moreover, they are most knowledgeable about the capacities and constraints of smallholder farmers. Linking local village traders directly to modern retail markets, or initially linking them to intermediaries in respective supply chains, could be a promising way to increase the participation of smallholder farmers.

Yet the possibilities that traditional wholesale and retail markets offer smallholder farmers should not be overlooked. Our analysis has shown that traditional markets, and in particular wet markets, still play an important role for smallholder farmers, and that this type of market best suits their needs. Moreover, Thailand is a fastdeveloping nation and a good example of a country where the expansion of modern retail structures is already at an advanced stage of development; it is therefore to be expected that, in other developing countries, traditional markets are also still very important.

In Thailand the following pattern, which is likely to apply in other countries as well, could be observed: Economic growth leads to increasing welfare in many households which is then reflected in changing consumption patterns. Consumers start to spend more money on high-value products and other quality or convenience-based products. This results in new opportunities to earn income. However, these opportunities were exploited by multinational retail chains, which expanded rapidly and implemented their own marketing structures. The transformation of agro-food systems wasn't really a true transformation, which could have brought about the restructuring of traditional structures, but the parallel establishment of modern retail structures. The result of the latter is that modern retail markets reap most of the benefits from 
overall economic growth, whereas traditional wholesale and retail markets appear to remain unchanged. In other words, the majority of smallholder farmers have missed out on the transformation of agro-food systems.

Nevertheless, traditional markets still have the ability to react to changing consumer preferences and to benefit from the implications of overall economic growth. Keeping in mind the developments of retail structures and the disappearance of traditional wet markets in Europe, traditional markets must actively compete with modern retail markets. A restructuring slogan particularly appropriate for wet markets could be 'Transforming from traditional to modern, yet nevertheless remaining a wet market'. The wet markets' features which consumers value should be kept, and features which are only found in modern retail markets should be added. This holds true with regard to the overall market appearance, e.g. cleanliness, issues of convenience (parking lots, etc.) and especially to the products offered. The latter includes not only product quality but also how the products are displayed. All in all, wet markets need to become an attractive place for middle and upper income customers to shop. If wet markets undertake these changes, the traditional agro-food systems would be transformed, and the main players of the original supply chains, and thus smallholder farmers, would benefit. 


\section{References}

Abdulai, A. and Huffman, W.E., 2005. The diffusion of new agricultural technologies: the case of crossbred-cow technology in Tanzania. American Journal of Agricultural Economics 87, 645-659.

Adamowicz, W., Louviere, J. and Swait, J., 1998. Introduction to attribute-based stated choice methods. Report to NOAA Resource Valuation Branch, Damage Assessment Centre, Silver Spring, MD.

Asfaw, A., 2007. Supermarket purchases and the dietary patterns of households in Guatemala. Discussion Paper No. 696, IFPRI, Washington, DC.

Asfaw, S., Mithöfer, D. and Waibel, H., 2009. Investment in compliance with GLOBALGAP standards: does it pay off for small-scale producers in Kenya? Quarterly Journal of International Agriculture 48, 337-362.

Balsevich, F., Berdegué, J.A., Flores, L., Mainville, D. and Reardon, T., 2003. Supermarkets and produce quality and safety standards in Latin America. American Journal of Agricultural Economics 85, 1147-1154.

Balsevich, F., Berdegué, J. and Reardon, T., 2006. Supermarkets, new-generation wholesalers, tomato farmers, and NGOs in Nicaragua. Staff Paper No. 3, Department of Agricultural Economics, Michigan State University. 
Berdegué, J., Balsevich, F., Flores, L. and Reardon, T., 2005. Central American supermarkets ' private standards of quality and safety in procurement of fresh fruits and vegetables. Food Policy 30, 254-269.

Berdegué, J.A., Reardon, T., Balsevich, F., Martínez, A., Medina, R., Aguirre, M. and Echánove, F., 2006. Supermarkets and Michoacán guava farmers in Mexico. Staff Paper No.16, Department of Agricultural Economics, Michigan State University.

Big C, 2009. http://www.bigc.co.th/en/stores/. Downloaded on 30 November, 2009.

Bignebat, C., Koc, A.A. and Lemeilleur, S., 2009. Small producers, supermarkets, and the role of intermediaries in Turkey's fresh fruit and vegetable market. Agricultural Economics 40, 807-816.

Blandon, J., Henson, S. and Islam, T., 2009. Marketing preferences of small-scale farmers in the context of new agrifood systems: a stated choice model. Agribusiness 25, 251-267.

Bolwig, S., Gibbon, P. and Jones, S., 2009. The economics of smallholder organic contract farming in tropical Africa. World Development 37, 1094-1104.

Boselie, D., Henson, S. and Weatherspoon, D., 2003. Supermarket procurement practices in developing countries: redefining the roles of the public and private sectors. American Journal of Agricultural Economics 85, 1155-1161.

Burton, M., Rigby, D. and Young, T., 2003. Modelling the adoption of organic horticultural technology in the UK using duration analysis. Australian Journal of Agricultural and Resource Economics 47, 29-54.

Campbell, D., Hutchinson, W.G. and Scarpa, R., 2006. Using discrete choice experiments to derive individual-specific WTP estimates for landscape improvements under agri-environmental schemes: evidence from the rural environment protection scheme in Ireland. FEEM Working Paper 26, Milano, Italy.

Carrefour, 2009. http://www.carrefour.co.th/eng/Map.aspx. Downloaded on 30 November, 2009.

Carletto, C., de Janvry, A. and Sadoulet, E., 1999. Sustainability in the diffusion of innovations: smallholder nontraditional agro-exports in Guatemala. Economic Development and Cultural Change 47, 345-369. 
Carletto, C., Kirk, A., Winter, P. and Davis, B., 2007. Non-traditional crops, traditional constraints: the adoption and diffusion of export crops among Guatemalan smallholders. Policy Research Working Paper No.4347, World Bank, Washington, DC.

Cleves, M.A., Gould, W.W. and Gutierrez, R.G., 2002. An introduction to survival analysis using Stata. Stata Press, College Station, TX.

Colombo, S., Hanley, N. and Calatrava-Requena, J., 2005. Designing policy for reducing the off-farm effects of soil erosion using choice experiments. Journal of Agricultural Economics 56, 81-95.

D’Emden, F.H., Llewellyn, R.S. and Burton, M.P., 2008. Factors influencing adoption of conservation tillage in Australian cropping regions. Australian Journal of Agricultural and Resource Economics 52, 169-182.

D'Haese, M. and van Huylenbroeck, G., 2005. The rise of supermarkets and changing expenditure patterns of poor rural households case study in the Transkei area, South Africa. Food Policy 30, 97-113.

Dadi, L., Burton, M. and Ozanne, A., 2004. Duration analysis of technological adoption in Ethiopian agriculture. Journal of Agricultural Economics 55, 613-631.

Dirven, M. and Faiguenbaum, S., 2008. The role of Santiago wholesale markets in supporting small farmers and poor consumers. In: McCullough, E.B., Pingali, P.L. and Stamoulis, K.G., eds., The transformation of agri-food systems. FAO and Earthscan, London.

Dolan, C. and Humphrey, J., 2000. Governance and trade in fresh vegetables: the impact of UK supermarkets on the African horticulture industry. Journal of Development Studies 37, 147-176.

Edmeades, S., 2007. A hedonic approach to estimating the supply of variety attributes of a subsistence crop. Agricultural Economics 37, 19-28.

Faiguenbaum, S., Berdegué, J.A. and Reardon, T., 2002. The rapid rise of supermarkets in Chile: effects on dairy, vegetable, and beef chains. Development Policy Review 20, 459-471.

Farina, E., 2002. Consolidation, multinationalization, and competition in Brazil: impacts on horticulture and dairy product systems. Development Policy Review 20, 441-457. 
Feder, G., Just, R.E. and Zilberman, D., 1985. Adoption of agricultural innovations in developing countries: a survey. Economic Development and Cultural Change 33, 255-298.

Foodland, 2009. www.foodland.co.th/home.htm. Downloaded on 30 November, 2009.

Fuglie, K.A. and Kascak, C.A., 2003. Adoption and diffusion of natural-resourceconserving agricultural technology. Review of Agricultural Economics 23, 386-403.

Gibbon, P., 2003. Value-chain governance, public regulation and entry barriers in the global fresh fruit and vegetable chain in the EU. Development Policy Review $21,615-625$.

Glover, D., 1987. Increasing the benefits to smallholders from contract farming: problems for farmers' organizations and policy makers. World Development $15,441-448$.

Gonzalez, C., Johnson, N. and Qaim, M., 2009. Consumer acceptance of secondgeneration GM foods: the case of biofortified cassava in the north-east of Brazil. Journal of Agricultural Economics 60, 604-624.

Gow, H. and Swinnen, J., 2001. Private enforcement capital and contract enforcement in transition economies. American Journal of Agricultural Economics 83, 686-690.

Greene, W.H., 2003. Econometric analysis. Prentice Hall, Upper Saddle River, NJ.

Gregg, D., 2009. Non adoption of improved maize varieties in East Timor. Paper presented at the 53rd Annual Conference of the Australian Agricultural and Resource Economics Society. Cairns, Australia, February 11-13.

Guo, H. and Jolly, R.W., 2008. Contractual arrangements and enforcement in transition agriculture: theory and evidence from China. Food Policy 33, 570- 575.

Guo, H., Jolly, R.W. and Zhu, J., 2007. Contract farming in China: perspectives of farm households and agribusiness firms. Comparative Economic Studies 49, 285-312.

Gutman, G., 2002. Impact of the rapid rise of supermarkets on dairy products systems in Argentina. Development Policy Review 20, 409-427. 
Hawkes, C., 2008. Dietary implications of supermarket development: a global perspective. Development Policy Review 26, 657-692.

Henson, S. and Reardon, T., 2005. Private agri-food standards: implications for food policy and the agri-food system. Food Policy 30, 241-253.

Henson, S., Masakure, O. and Boselie, D., 2005. Private food safety and quality standards for fresh produce exporters: the case of Hortico Agrisystems, Zimbabwe. Food Policy 30, 371-384.

Hernández, R., Reardon, T. and Berdegué, J., 2007. Supermarkets, wholesalers, and tomato growers in Guatemala. Agricultural Economics 36, 281-290.

Ho, S.C., 2005. Evolution versus tradition in marketing systems: the Hong Kong food-retailing experience. Journal of Public Policy and Marketing 24, 90-9.

Hole, A., 2007. Fitting mixed logit models by using maximum simulated likelihood. Stata Journal 7, 388 - 401.

Hu, D., Reardon, T., Rozelle, S., Timmer, P. and Wang, H., 2004. The emergence of supermarkets with Chinese characteristics: challenges and opportunities for China’s agricultural development. Development Policy Review 22, 557-586.

Huang, J., Wu, Y. and Rozelle, S., 2008. Marketing China's fruit: are small poor farmers being excluded from the supply chain? In: McCullough, E.B., Pingali, P.L. and Stamoulis, K.G., eds., The transformation of agri-food systems. FAO and Earthscan, London.

Humphrey, J., McCulloch, N., and Ota, M., 2004. The impact of European market changes on employment in the Kenyan horticulture sector. Journal of International Development 16, 63-80.

Ladd, G.W. and Savannunt, V., 1976. A model of consumer goods characteristics. American Journal of Agricultural Economics 58, 504-510.

Lancaster, K.J., 1966. A new approach to consumer theory. Journal of Political Economies 74, 132-157.

Lancsar, E. and Louviere, J., 2006. Deleting irrational responses from discrete choice experiments: a case of investigating or imposing preferences? Health Economics $15,797-811$.

Layton, D. and Brown, G., 2000. Heterogeneous preferences regarding global climate change. Review of Economics and Statistics 82, 616-624. 
Louviere, J.J. and Woodworth, G., 1983. Design and analysis of simulated consumer choice or allocative experiments: an approach based on aggregate data. Journal of Marketing Research 20, 350-367.

Louviere, J.J., Hensher, D. and Swait, J., 2000. Stated choice methods: analysis and applications. Cambridge University Press.

Maertens, M., 2009. Horticulture exports, agro-industrialization, and farm-nonfarm linkages with the smallholder farm sector: evidence from Senegal. Agricultural Economics 40, 219-229.

Maertens, M. and Swinnen, J.F.M., 2009. Trade, standards, and poverty: evidence from Senegal. World Development 37, 161-178.

Mangala, K. and Chengappa, P., 2008. A novel agribusiness model for backward linkages with farmers: a case of food retail chain. Agricultural Economics Research Review 21 (conference proceedings), 363-370.

Masakure, O. and Henson, S., 2005. Why do small-scale producers choose to produce under contract? Lessons from nontraditional vegetable exports from Zimbabwe. World Development 33, 1721-1733.

Matuschke, I. and Qaim, M. 2009. The impact of social networks on hybrid seed adoption in India. Agricultural Economics 40, 493-505.

Matuschke, I. and Qaim, M., 2008. Seed market privatisation and farmers' access to crop technologies: The case of hybrid pearl millet adoption in India. Journal of Agricultural Economics 59, 498-515.

McCulloch, N., 2002. Export horticulture and poverty in Kenya. Working Paper No.174, IDS, Sussex, Brighton, UK.

McFadden, D., 1980. Econometric models for probalistic choice among products. The Journal of Business, 53, 13-29.

Mergenthaler, M., Weinberger, K. and Qaim, M., 2009. The food system transformation in developing countries: a disaggregate demand analysis for fruits and vegetables in Vietnam. Food Policy 34, 426-436.

Meijer, M., Rodgriguez, I., Lundy, M. and Hellin, J., 2008. Supermarkets and small farmers: the case of fresh vegetables in Honduras. In: McCullough, E.B., Pingali, P.L. and Stamoulis, K.G., eds., The transformation of agri-food systems. FAO and Earthscan, London. 
Minten, B. and Reardon, T., 2008. Food prices, quality, and quality's pricing in supermarkets versus traditional markets in developing countries. Review of Agricultural Economics 30, 480-490.

Minten, B., Randrianarison, L. and Swinnen, J.F.M., 2009. Global retail chains and poor farmers: evidence from Madagascar. World Development 37, 17281741.

Miyata, S., Minot, N. and Hu, D., 2009. Impact on contract farming on income: Linking small farmers, packers, and supermarkets in China. World Development 37, 1781-1790.

Nagaraj, N., Chandrakanth, M.G., Chengappa, P.G., Roopa, H.S. and Chandakavate, P.M., 2008. Contract farming and its implications for input-supply, linkages between markets and farmers in Karnataka. Agricultural Economics Research Review 21 (conference proceedings), 307-316.

Natawidjaja, R., Reardon, T., Shetty, S. with Noor, T.I., Perdana, T., Rasmikayati, E., Bachri, S. and Hernández, R., 2007. Horticultural producers and supermarket development in Indonesia. Report No. 38543, World Bank, Jakarta.

Neven, D. and Reardon, T., 2006. Kenyan supermarkets and horticultural farm sector development. Paper presented at the International Association of Agricultural Economists Conference. Gold Coast, Australia, August 12-18.

Neven, D. and Reardon, T., 2008. The rapid rise of Kenyan supermarkets: impacts on the fruit and vegetable supply system. In: McCullough, E.B., Pingali, P.L. and Stamoulis, K.G., eds., The transformation of agri-food systems. FAO and Earthscan, London.

Neven, D., Reardon, T., Chege, J. and Wang, H., 2006. Supermarkets and consumers in Africa: the case of Nairobi, Kenya. Journal of International Food \& Agribusiness Marketing 18, 103 - 123.

Neven, D., Odera, M.M., Reardon, T. and Wang, H., 2009. Kenyan supermarkets, emerging middle-class horticultural farmers, and employment impacts on the rural poor. World Development 37, 1802-1811.

Peterson, H.C., Wysockib, A. and Harsha, S.B., 2001. Strategic choice along the vertical coordination continuum. International Food and Agribusiness Management Review 4, 149-166. 
Pingali, P. (2006). Westernization of Asian diets and the transformation of food systems: implications for research and policy. Food Policy 32, 281-298.

Rahman, S., Wiboonpongse, A., Sriboonchitta, S. and Chaovanapoonphol, Y., 2009. Production efficiency of Jasmine rice producers in northern and north-eastern Thailand. Journal of Agricultural Economics 60, 419-435.

Randela, R., Alemu, Z.G. and Groenewald, J.A., 2008. Factors enhancing market participation by small-scale cotton farmers. Agrekon 47, 451-469.

Reardon, T. and Farina, E.M., 2001. The rise of private food quality and safety standards: illustrations from Brazil. International Food and Agribusiness Management Review 4 , 413-421.

Reardon, T. and Berdegué, J.A., 2002. The rapid rise of supermarkets in Latin America: challenges and opportunities for development. Development Policy Review 20, 371-388.

Reardon, T. and Berdegué, J.A., 2006. The retail-led transformation of agrifood systems and its implications for development policies. Background Paper prepared for the World Development Report 2008 'Agriculture for Development', RIMISP-Latin American Center for Rural Development, Santiago, Chile.

Reardon, T. and Timmer, C.P., 2007. Transformation of markets for agricultural output in developing countries since 1950: how has thinking changed? In: Evenson, R.E., Pingali, P., eds., Handbook of Agricultural Economics, Vol. 3, Elsevier- Amsterdam.

Reardon, T., Timmer, C.P., Barrett, C.B. and Berdegué, J., 2003. The rise of supermarkets in Africa, Asia, and Latin America. American Journal of Agricultural Economics 85, 1140-1146.

Reardon, T., Berdegué, J.A and Timmer, C. P., 2005. Supermarketization of the 'emerging markets' of the Pacific Rim: development and trade implications. Journal of Food Distribution Research 36, 3-12.

Reardon, T., Henson, S. and Berdegué, J., 2007. Proactive fast-tracking' diffusion of supermarkets in developing countries: implications for market institutions and trade. Journal of Economic Geography 7, 399-431. 
Reardon, T., Barrett, C.B., Berdegué, J.A. and Swinnen, J.F.M. 2009. Agrifood industry transformation and small farmers in developing countries. World Development $37,1717-1727$.

Reardon, T., Henson, S. and Gulati, A., 2010. Links between supermarkets and food prices, diet diversity and food safety in developing countries. In: Hawkes, C., Blouin, C., Henson, S., Drager, N. and Dubé, L., eds., Trade, food, diet and health: perspectives and policy options. Wiley-Blackwell. In Press.

Roy, D. and Thorat, A., 2008. Success in high value horticultural export markets for the small farmers: the case of Mahagrapes in India. World Development 36, 1874-1890.

Sartorius, K. and Kirsten, J., 2007. A framework to facilitate institutional arrangements for smallholder supply in developing countries: an agribusiness perspective. Food Policy 32, 640-655.

Schwentesius, R. and Manuel, A.G., 2002. Supermarkets in Mexico: impacts on horticultural systems. Development Policy Review 20, 487-502.

Simmons, P., Winters, P. and Patrick, I., 2005. An analysis of contract farming in East Java, Bali, and Lombok, Indonesia. Agricultural Economics 33, 513525 .

Singh, B.P., 2002. Nontraditional crop production in Africa for export. In Janick, J. and Whipkey, A., eds., Trends in new crops and new uses. ASHS Press, Alexandria, VA.

Singh, S., 2002. Contracting out solutions: political economy of contract farming in the Indian Punjab. World Development 30, 1621-1638.

Sirikeratikul, S., 2004. Thailand: retail food sector 2004. GAIN Report TH4143, USDA Foreign Agricultural Service, Washington, DC.

Stokke, H.E., 2009. Multinational supermarket chains in developing countries: does local agriculture benefit? Agricultural Economics 40, 645-656.

Stringer, R., Sang, N. and Croppenstedt, A., 2009. Producers, processors, and procurement decisions: the case of vegetable supply chains in China. World Development $37,1773-1780$. 
Suddeephong, R., 2010. Consumers' preferences for fresh fruits and vegetables in metropolitan areas of Bangkok and Chiang Mai. Doctoral Thesis, unpublished.

Suryadarma, D., Poesoro, A., Budiyati, S. and Rosfadhila, A.M., 2007. Impact of supermarkets on traditional markets and retailers in Indonesia's urban centers. Research Report, SMERU Research Institute, Jakarta, Indonesia.

Swinnen, J.F.M., 2007. Global supply chains, standards and the poor. CAB International, Wallingford.

Takane, T., 2004. Smallholders and nontraditional exports under economic liberalization: The case of pineapples in Ghana. African Study Monographs 25, Center for African Area Studies, Kyoto University, Kyoto.

Tesco Lotus, 2009. http://www.tescolotus.com/left.php?lang=en\&menu=location th\&data $=$ searchlocation. Downloaded on 30 November, 2009.

Thailand Development Research Institute, 2002. The retail business in Thailand: impact of the large scale multinational corporation retailers. Bangkok. (In Thai).

Timmer, C.P., 2009. Do supermarkets change the food policy agenda? World Development $37,1812-1819$.

Tokrisna, R., 2006. Thailand changing retail sector: consequences for consumers, producers and trade. Economic Profile Paper, Pacific Economic Cooperation Council, Singapore.

Tops, 2009. http://www.tops.co.th/main.html; Downloaded on 30 November, 2009.

Traill, W.B., 2006. The rapid rise of supermarkets. Development Policy Review 24, 163-174.

Vandeplas, A., Minten, B. and Swinnen, J.F.M., 2009. On food quality in domestic markets of developing economies. Paper presented at the International Association of Agricultural Economists Conference. Beijing, China, August 1622, 2009.

Vandergeest, P., 2006. Natural markets: remaking food and agriculture in Southeast Asia. Paper presented at the Annual Meeting of the Association of American Geographers. Chicago, U.S., March 7-11, 2006. 
von Braun, J., Hotchkiss, D. and Immink, M., 1989. Nontraditional export crops in Guatemala: effects on production, income and nutrition. Research Report No. 73, IFPRI, Washington, DC.

Ward, C.E., Lusk, J.L. and Dutton, J.M., 2008. Implicit value of retail beef product attributes. Journal of Agricultural and Resource Economics 33, 364-381.

Weatherspoon, D.D. and Reardon, T., 2003. The rise of supermarkets in Africa: implications for agrifood systems and the rural poor. Development Policy Review 21, 333-355.

Wiboonpongse, A. and Sriboonchitta, S., 2004. Securing small producers participation in restructured national and regional agri-food systems in Thailand. Research Report, IIED Regoverning Markets Program, Chiang Mai University, Chiang Mai.

Wiboonpongse, A., Sriboonchitta, S., Gypmantasiri, P. and Thong-Ngam, K., 1998. The role of contract farming in agricultural transition in Thailand. The International Society for Southeast Asian Agricultural Sciences (ISSAAS) Journal 4, 74-97.

Wooldridge, J.M., 2009. Introductory Economics: a modern approach. SouthWestern Cengage Learning, Mason, Ohio.

World Bank, 2008. Agriculture for development. World Development Report, Washington, DC. 